\title{
Review of the global models used within phase 1 of the Chemistry-Climate Model Initiative (CCMI)
}

\author{
Olaf Morgenstern ${ }^{1}$, Michaela I. Hegglin ${ }^{2}$, Eugene Rozanov ${ }^{18,5}$, Fiona M. O’Connor ${ }^{14}$, N. Luke Abraham ${ }^{17,20}$, \\ Hideharu Akiyoshi $^{8}$, Alexander T. Archibald ${ }^{17,20}$, Slimane Bekki ${ }^{21}$, Neal Butchart ${ }^{14}$, Martyn P. Chipperfield ${ }^{16}$, \\ Makoto Deushi $^{15}$, Sandip S. Dhomse ${ }^{16}$, Rolando R. Garcia ${ }^{7}$, Steven C. Hardiman ${ }^{14}$, Larry W. Horowitz ${ }^{13}$, \\ Patrick Jöckel $^{10}$, Beatrice Josse ${ }^{9}$, Douglas Kinnison ${ }^{7}$, Meiyun Lin ${ }^{13,23}$, Eva Mancini ${ }^{3}$, Michael E. Manyin ${ }^{12,22}$, \\ Marion Marchand ${ }^{21}$, Virginie Marécal ${ }^{9}$, Martine Michou ${ }^{9}$, Luke D. Oman ${ }^{12}$, Giovanni Pitari ${ }^{3}$, David A. Plummer ${ }^{4}$, \\ Laura E. Revell ${ }^{5,6}$, David Saint-Martin ${ }^{9}$, Robyn Schofield ${ }^{11}$, Andrea Stenke ${ }^{5}$, Kane Stone ${ }^{11, a}$, Kengo Sudo ${ }^{19}$, \\ Taichu Y. Tanaka ${ }^{15}$, Simone Tilmes ${ }^{7}$, Yousuke Yamashita ${ }^{8, b}$, Kohei Yoshida ${ }^{15}$, and Guang Zeng ${ }^{1}$ \\ ${ }^{1}$ National Institute of Water and Atmospheric Research (NIWA), Wellington, New Zealand \\ ${ }^{2}$ Department of Meteorology, University of Reading, Reading, UK \\ ${ }^{3}$ Department of Physical and Chemical Sciences, Universitá dell' Aquila, L'Aquila, Italy \\ ${ }^{4}$ Environment and Climate Change Canada, Montréal, Canada \\ ${ }^{5}$ Institute for Atmospheric and Climate Science, ETH Zürich (ETHZ), Zürich, Switzerland \\ ${ }^{6}$ Bodeker Scientific, Christchurch, New Zealand \\ ${ }^{7}$ National Center for Atmospheric Research (NCAR), Boulder, Colorado, USA \\ ${ }^{8}$ National Institute of Environmental Studies (NIES), Tsukuba, Japan \\ ${ }^{9}$ CNRM UMR 3589, Météo-France/CNRS, Toulouse, France \\ ${ }^{10}$ Institut für Physik der Atmosphäre, Deutsches Zentrum für Luft- und Raumfahrt (DLR), Oberpfaffenhofen, Germany \\ ${ }^{11}$ School of Earth Sciences, University of Melbourne, Melbourne, Victoria, Australia \\ ${ }^{12}$ National Aeronautics and Space Administration Goddard Space Flight Center (NASA GSFC), Greenbelt, Maryland, USA \\ ${ }^{13}$ National Atmospheric and Ocean Administration Geophysical Fluid Dynamics Laboratory (NOAA GFDL), Princeton, New \\ Jersey, USA \\ ${ }^{14}$ Met Office Hadley Centre (MOHC), Exeter, UK \\ ${ }^{15}$ Meteorological Research Institute (MRI), Tsukuba, Japan \\ ${ }^{16}$ School of Earth and Environment, University of Leeds, Leeds, UK \\ ${ }^{17}$ Department of Chemistry, University of Cambridge, Cambridge, UK \\ ${ }^{18}$ Physikalisch-Meteorologisches Observatorium Davos - World Radiation Center (PMOD/WRC), Davos, Switzerland \\ ${ }^{19}$ Graduate School of Environmental Studies, Nagoya University, Nagoya, Japan \\ ${ }^{20}$ National Centre for Atmospheric Science (NCAS), UK \\ ${ }^{21}$ LATMOS, Institut Pierre Simon Laplace (IPSL), Paris, France \\ ${ }^{22}$ Science Systems and Applications, Inc., Lanham, Maryland, USA \\ ${ }^{23}$ Princeton University Program in Atmospheric and Oceanic Sciences, Princeton, New Jersey, USA \\ ${ }^{a}$ now at: Massachusetts Institute of Technology (MIT), Boston, Massachusetts, USA \\ ${ }^{b}$ now at: Japan Agency for Marine-Earth Science and Technology (JAMSTEC), Yokohama, Japan
}

Correspondence to: Olaf Morgenstern (olaf.morgenstern@niwa.co.nz)

Received: 27 July 2016 - Discussion started: 14 September 2016

Revised: 16 December 2016 - Accepted: 9 January 2017 - Published: 13 February 2017 
Abstract. We present an overview of state-of-the-art chemistry-climate and chemistry transport models that are used within phase 1 of the Chemistry-Climate Model Initiative (CCMI-1). The CCMI aims to conduct a detailed evaluation of participating models using process-oriented diagnostics derived from observations in order to gain confidence in the models' projections of the stratospheric ozone layer, tropospheric composition, air quality, where applicable global climate change, and the interactions between them. Interpretation of these diagnostics requires detailed knowledge of the radiative, chemical, dynamical, and physical processes incorporated in the models. Also an understanding of the degree to which CCMI-1 recommendations for simulations have been followed is necessary to understand model responses to anthropogenic and natural forcing and also to explain intermodel differences. This becomes even more important given the ongoing development and the ever-growing complexity of these models. This paper also provides an overview of the available CCMI-1 simulations with the aim of informing CCMI data users.

\section{Introduction}

Climate models have been evolving considerably in recent decades. From relatively simple beginnings, ever more components have been added, until presently the "Earth System Models" (ESMs) define the state of the field. Such models simultaneously serve a variety of purposes including simulating air quality, tropospheric chemistry, stratospheric ozone, and global climate. These applications are strongly coupled; e.g. various air pollutants are climate active, stratospheric and tropospheric ozone are coupled in a variety of ways, and climate change affects atmospheric composition and vice versa. Previous-generation models were usually constructed for just one of these purposes (e.g. Morgenstern et al., 2010; Lamarque et al., 2013). Furthermore, increasingly biogeochemical feedbacks are considered, e.g. in the form of organic aerosol precursors emitted from land and ocean surfaces. However, the additional complexity characterizing ESMs makes these simulations more difficult to evaluate because previously ignored feedbacks now need to be considered.

The purpose of this paper is to document the internal make-up of 20 chemistry-climate models (CCMs) and chemistry-transport models (CTMs) participating in phase 1 of the Chemistry-Climate Model Initiative (CCMI; Eyring et al., 2013a), a combined activity of the International Global Atmospheric Chemistry (IGAC) and Stratospheretroposphere Processes And their Role in Climate (SPARC) projects. CCMs are a major stepping stone on the way towards ESMs, combining physical climate models with an explicit representation of atmospheric chemistry. CCMI- 1 continues the legacy of previous CCM inter-comparisons, par- ticularly the Chemistry-Climate Model Validation (CCMVal; SPARC, 2010) and the Atmospheric Chemistry and Climate Model Intercomparison Project (ACCMIP; Lamarque et al., 2013). These precursors had more limited aims than CCMI; in the case of CCMVal, the main aim was to inform the World Meteorological Organization's Scientific Assessments of Ozone Depletion (WMO, 2007, 2011, 2015) with state-of-the-science information about stratospheric ozone and its past and projected future evolution. The main outcome was SPARC (2010), a comprehensive assessment of the performance of stratospheric CCMs. In the case of ACCMIP, the aim was to inform the 5th Assessment Report of the Intergovernmental Panel on Climate Change (IPCC, 2013) about the roles of "near-term climate forcers", notably tropospheric ozone and aerosols, in historical and future climate change. CCMI-1 builds on CCMVal and ACCMIP by encouraging the participation of coupled atmosphereocean-stratosphere-troposphere models that represent the various ways in which stratospheric and tropospheric composition are coupled to each other and to the physical climate more consistently than in their predecessor models. A second phase of CCMI, CCMI-2, is planned, where simulations will be conducted jointly with the Aerosol Comparisons between Observations and Models (AEROCOM) project and will contribute to the 6th Coupled Model Intercomparison Project (CMIP6) under the Aerosols and Chemistry Model Intercomparison Project (AerChemMIP; Collins et al., 2016). These will be performed with next-generation models under development and will not be discussed here (http://blogs.reading.ac.uk/ccmi/).

For CCMVal, Morgenstern et al. (2010) described salient model features of CCMVal-2 models, mostly in tabular forms. Their paper builds on numerous publications that describe individual models, or aspects thereof. Here we present an update to the tables in Morgenstern et al. (2010), focussing in the accompanying text on the changes that have occurred in the participating models since CCMVal-2. (In all but three cases, older versions of the CCMI- 1 models had participated in CCMVal-2; see below.) This paper is meant to support other publications evaluating the CCMI-1 simulations by providing an overview of the make-up of CCMI-1 models as well as a comprehensive literature list for further reading.

\section{Participating models}

There are 20 models participating in CCMI-1 (Tables 1 and 2). With three exceptions (CHASER (MIROC-ESM), TOMCAT, MOCAGE), each participating model had a predecessor model in CCMVal-2; hence, the focus here will be on developments since CCMVal-2. MOCAGE participated in ACCMIP (Lamarque et al., 2013). Corresponding to the much broader scope of CCMI, relative to CCMVal-2, salient developments in these models include whole-atmosphere 
Table 1. Participating models and contact information. For abbreviations of institution names, see the authors' affiliations.

\begin{tabular}{|c|c|c|c|}
\hline Model names & Institutions & Principal investigators (PIs) & Email addresses \\
\hline ACCESS CCM & $\begin{array}{l}\text { U. Melbourne, AAD, } \\
\text { NIWA }\end{array}$ & $\begin{array}{l}\text { K. Stone, } \\
\text { R. Schofield, } \\
\text { A. Klekociuk, } \\
\text { D. Karoly, O. Morgenstern }\end{array}$ & $\begin{array}{l}\text { stonek@mit.edu } \\
\text { robyn.schofield@unimelb.edu.au } \\
\text { andrew.klekociuk@aad.edu.au }\end{array}$ \\
\hline CCSRNIES MIROC3.2 & NIES & $\begin{array}{l}\text { H. Akiyoshi, } \\
\text { Y. Yamashita }\end{array}$ & $\begin{array}{l}\text { hakiyosi@nies.go.jp } \\
\text { yyousuke@jamstec.go.jp }\end{array}$ \\
\hline CESM1 CAM4-chem & NCAR & $\begin{array}{l}\text { S. Tilmes, } \\
\text { J.-F. Lamarque }\end{array}$ & $\begin{array}{l}\text { tilmes@ucar.edu } \\
\text { lamar@ucar.edu }\end{array}$ \\
\hline CESM1 WACCM & NCAR & $\begin{array}{l}\text { D. Kinnison, } \\
\text { R. R. Garcia, } \\
\text { A. K. Smith, } \\
\text { A. Gettelman, } \\
\text { D. Marsh, } \\
\text { C. Bardeen, } \\
\text { M. Mills }\end{array}$ & $\begin{array}{l}\text { dkin@ucar.edu } \\
\text { rgarcia@ucar.edu } \\
\text { aksmith@ucar.edu } \\
\text { andrew@ucar.edu } \\
\text { marsh@ucar.edu } \\
\text { bardeenc@ucar.edu } \\
\text { mmills@ucar.edu }\end{array}$ \\
\hline CHASER (MIROC-ESM) & $\begin{array}{l}\text { U. Nagoya, JAMSTEC, } \\
\text { NIES }\end{array}$ & $\begin{array}{l}\text { K. Sudo, } \\
\text { T. Nagashima }\end{array}$ & $\begin{array}{l}\text { kengo@nagoya-u.jp } \\
\text { nagashima.tatsuya@nies.go.jp }\end{array}$ \\
\hline CMAM & $\begin{array}{l}\text { CCCma, Environment and } \\
\text { Climate Change Canada }\end{array}$ & $\begin{array}{l}\text { D. Plummer, } \\
\text { J. Scinocca }\end{array}$ & $\begin{array}{l}\text { david.plummer@canada.ca } \\
\text { john.scinocca@canada.ca }\end{array}$ \\
\hline CNRM-CM5-3 & $\begin{array}{l}\text { CNRM Météo-France } \\
\text { CNRS - CERFACS }\end{array}$ & $\begin{array}{l}\text { M. Michou, } \\
\text { D. Saint-Martin }\end{array}$ & $\begin{array}{l}\text { martine.michou@meteo.fr } \\
\text { david.saint-martin@meteo.fr }\end{array}$ \\
\hline EMAC & $\begin{array}{l}\text { DLR-IPA, KIT-IMK-ASF, } \\
\text { KIT-SCC-SLC, FZJ-IEK-7, } \\
\text { FUB, UMZ-IPA, } \\
\text { MPIC, CYI }\end{array}$ & $\begin{array}{l}\text { P. Jöckel, H. Tost, A. Pozzer, M. Kunze, } \\
\text { O. Kirner, S. Brinkop, D. S. Cai, J. Eckstein, } \\
\text { F. Frank, H. Garny, K.-D. Gottschaldt, P. Graf, } \\
\text { V. Grewe, A. Kerkweg, B. Kern, S. Matthes, } \\
\text { M. Mertens, S. Meul, M. Nützel, } \\
\text { S. Oberländer-Hayn, R. Ruhnke, R. Sander }\end{array}$ & $\begin{array}{l}\text { messy_admin@lists.mpic.de } \\
\text { patrick.joeckel@dlr.de }\end{array}$ \\
\hline GEOSCCM & NASA/GSFC & $\begin{array}{l}\text { L. D. Oman, } \\
\text { S. E. Strahan }\end{array}$ & $\begin{array}{l}\text { luke.d.oman@nasa.gov } \\
\text { susan.e.strahan@nasa.gov }\end{array}$ \\
\hline GFDL-AM3/CM3 & NOAA GFDL & $\begin{array}{l}\text { M. Y. Lin, } \\
\text { L. W. Horowitz }\end{array}$ & $\begin{array}{l}\text { meiyun.lin@noaa.gov } \\
\text { larry.horowitz@noaa.gov }\end{array}$ \\
\hline HadGEM3-ES & MOHC & $\begin{array}{l}\text { F. M. O’Connor, } \\
\text { N. Butchart, } \\
\text { S. C. Hardiman, S. T. Rumbold }\end{array}$ & $\begin{array}{l}\text { fiona.oconnor@metoffice.gov.uk } \\
\text { neal.butchart@metoffice.gov.uk }\end{array}$ \\
\hline LMDz-REPROBUS & IPSL & $\begin{array}{l}\text { S. Bekki, } \\
\text { M. Marchand, } \\
\text { F. Lott, D. Cugnet, L. Guez, } \\
\text { F. Lefevre, S. Szopa }\end{array}$ & $\begin{array}{l}\text { slimane@latmos.ipsl.fr } \\
\text { marion.marchand@latmos.ipsl.fr }\end{array}$ \\
\hline MOCAGE & Météo France CNRS & $\begin{array}{l}\text { B. Josse, } \\
\text { V. Marecal }\end{array}$ & $\begin{array}{l}\text { beatrice.josse@meteo.fr } \\
\text { virginie.marecal@meteo.fr }\end{array}$ \\
\hline MRI-ESM1r1 & & $\begin{array}{l}\text { M. Deushi, } \\
\text { T. Y. Tanaka, } \\
\text { K. Yoshida }\end{array}$ & $\begin{array}{l}\text { mdeushi@mri-jma.go.jp } \\
\text { yatanaka@ mri-jma.go.jp } \\
\text { kyoshida@mri-jma.go.jp }\end{array}$ \\
\hline NIWA-UKCA & NIWA & $\begin{array}{l}\text { O. Morgenstern, } \\
\text { G. Zeng }\end{array}$ & $\begin{array}{l}\text { olaf.morgenstern@niwa.co.nz } \\
\text { guang.zeng@niwa.co.nz }\end{array}$ \\
\hline SOCOL & PMOD/WRC, IAC/ETHZ & $\begin{array}{l}\text { E. Rozanov, } \\
\text { A. Stenke, } \\
\text { L. Revell }\end{array}$ & $\begin{array}{l}\text { eugene.rozanov@pmodwrc.ch } \\
\text { andrea.stenke@env.ethz.ch } \\
\text { laura.revell@env.ethz.ch }\end{array}$ \\
\hline TOMCAT & U. Leeds & $\begin{array}{l}\text { S. Dhomse, } \\
\text { M. P. Chipperfield }\end{array}$ & $\begin{array}{l}\text { m.chipperfield@leeds.ac.uk } \\
\text { s.s.dhomse@leeds.ac.uk }\end{array}$ \\
\hline
\end{tabular}


Table 1. Continued.

\begin{tabular}{|c|c|c|c|}
\hline Model names & Institutions & Principal investigators (PIs) & Email addresses \\
\hline ULAQ-CCM & U. L'Aquila & $\begin{array}{l}\text { G. Pitari, } \\
\text { E. Mancini, } \\
\text { G. Di Genova }\end{array}$ & $\begin{array}{l}\text { gianni.pitari@aquila.infn.it } \\
\text { eva.mancini@aquila.infn.it } \\
\text { glauco.digenova@aquila.infn.it }\end{array}$ \\
\hline UMSLIMCAT & U. Leeds & $\begin{array}{l}\text { S. Dhomse, } \\
\text { M. P. Chipperfield }\end{array}$ & $\begin{array}{l}\text { m.chipperfield@leeds.ac.uk } \\
\text { s.s.dhomse@leeds.ac.uk }\end{array}$ \\
\hline UMUKCA-UCAM & U. Cambridge & $\begin{array}{l}\text { N. L. Abraham, } \\
\text { A. T. Archibald, } \\
\text { R. Currie, } \\
\text { J. A. Pyle }\end{array}$ & $\begin{array}{l}\text { luke.abraham@atm.ch.cam.ac.uk } \\
\text { ata27@cam.ac.uk } \\
\text { rc454@cam.ac.uk } \\
\text { john.pyle@atm.ch.cam.ac.uk }\end{array}$ \\
\hline
\end{tabular}

chemistry (almost all CCMVal-2 models have been further developed to include tropospheric chemistry), coupling (now several of the CCMI-1 models include an interactive ocean), increased resolution for several of them, and progress in various areas of model physics.

In the following, we comment on noteworthy developments relative to the CCMVal-2 models (SPARC, 2010). Apart from some very high-level information (such as model names and contact information), all tabulated information about the models is in the Supplement.

\subsection{Family relationships between the models}

Like in CCMVal-2, some family relationships are apparent between different models (Table S1). For example, ACCESS-CCM, NIWA-UKCA, UMUKCA-UCAM, and HadGEM3-ES use similar atmosphere, ocean, and sea ice components (ACCESS-CCM and UMUKCA-UCAM are atmosphere-only). GFDL-AM3 is the atmosphere-only equivalent of GFDL-CM3. EMAC and SOCOL are both based on different versions of the ECHAM5 climate model. LMDz-REPROBUS-CM6 can be coupled to a similar version of the Nucleus for a European Model of the Ocean (NEMO; Madec, 2008) as NIWA-UKCA and HadGEM3$\mathrm{ES}$; however, at the time of writing this paper only the atmosphere-only CM5 version has been used for CCMI-1 simulations. CCSRNIES MIROC 3.2 uses a similar version of the MIROC atmosphere model as CHASER. CESM1 CAM4-chem is the low-top counterpart of CESM1 WACCM; i.e. troposphere-stratosphere aspects of the two models are generally identical.

\subsection{Atmosphere grids and resolution}

In CCMVal-2, one model (AMTRAC) used a novel grid that was neither latitude-longitude nor spectral, namely the cubed-sphere grid. While several modelling centres presently are working on new-generation models based on this or similar novel grids, in the CCMI-1 ensemble the GFDL successors to AMTRAC continue to use this grid; GEOSCCM has adopted this grid (Table 3 ). It is anticipated that more models will adopt novel grids in future model inter-comparisons, to improve scalability and computing efficiency.

The horizontal resolution of most models is unchanged versus CCMVal-2 and in the case of MOCAGE, ACCMIP, respectively (Table 3). ULAQ CCM, HadGEM3-ES, MRI ESM, CMAM, CNRM-CM5-3 (for chemistry), SOCOL, and LMDz-REPROBUS-CM6 have increased their horizontal resolution; now resolution ranges between roughly $5^{\circ}$ to less than $2^{\circ}$. In several cases, versus CCMVal- 2 the models have increased their vertical resolution, particularly CNRMCM5-3, LMDz-REPROBUS, MRI ESM, ULAQ CCM, and HadGEM3-ES (Tables 3, S2). Vertical ranges are essentially unchanged versus the models' CCMVal-2 (or ACCMIP, for MOCAGE) counterparts with the uppermost model levels ranging from $35 \mathrm{~km}$ (for MOCAGE) to $140 \mathrm{~km}$ (for CESM1 WACCM). All but two models (CESM1 CAM4-chem, model top at $200 \mathrm{~Pa}$, MOCAGE - 500 Pa) completely cover the stratosphere (assuming a stratopause pressure of $100 \mathrm{~Pa}$ ). CESM1 CAM4-chem is the low-top equivalent of CESM1 WACCM, so simulations by these two models can be analysed for the role of the model top height (Table S2).

\subsection{Advection}

In CCMVal-2, there were some models that used different transport schemes for hydrological versus chemical tracers (Morgenstern et al., 2010). For CCMI-1, all CCMs (which transport both types of tracers) employ the same transport scheme for both (Tables S3, S4). This makes the advection of all tracers physically self-consistent.

\subsection{Time stepping and calendars}

Atmosphere models use a variety of time steps for the dynamical core, physical processes, radiation, transport, chemistry, and the coupling of chemistry and dynamics for different reasons. Generally the choice of time step is the result of a compromise between the computational cost associated with short time steps and the reduced accuracy associated with larger time steps. There is a considerable amount of diversity in the CCMI-1 ensemble regarding the choices of time steps 
Table 2. Model versions and key references. More details on the CCMVal-2 versions are in Morgenstern et al. (2010).

\begin{tabular}{|c|c|c|c|}
\hline Model & Revision/version & Reference(s) & CCMVal-2 precursor model \\
\hline $\begin{array}{l}\text { ACCESS CCM, } \\
\text { NIWA-UKCA }\end{array}$ & MetUM 7.3 & $\begin{array}{l}\text { Morgenstern et al. }(2009,2013) \text {, } \\
\text { Stone et al. (2016) }\end{array}$ & $\begin{array}{l}\text { UMUKCA-UCAM } \\
\text { (MetUM 6.1) }\end{array}$ \\
\hline CCSRNIES MIROC3.2 & 3.2 & Imai et al. (2013); Akiyoshi et al. (2016) & CCSRNIES \\
\hline CESM1 CAM4-chem & CCMI_23 & Tilmes (2015b) & CAM3.5 \\
\hline CESM1 WACCM & CCMI_30 & $\begin{array}{l}\text { Solomon et al. (2015); Garcia et al. (2016), } \\
\text { Marsh et al. (2013) }\end{array}$ & WACCM v3.5.48 \\
\hline $\begin{array}{l}\text { CHASER } \\
\text { (MIROC-ESM) }\end{array}$ & $\mathrm{v} 4.5$ & $\begin{array}{l}\text { Sudo et al. (2002); Sudo and Akimoto (2007), } \\
\text { Watanabe et al. (2011), } \\
\text { Sekiya and Sudo }(2012,2014)\end{array}$ & N/A \\
\hline CMAM & v2.1 & Jonsson et al. (2004); Scinocca et al. (2008) & CMAM \\
\hline CNRM-CM & v5-3 & $\begin{array}{l}\text { Voldoire et al. (2012); Michou et al. (2011), } \\
\text { http://www.cnrm-game-meteo.fr/ }\end{array}$ & CNRM-ACM \\
\hline EMAC & v2.51 & Jöckel et al. $(2010,2016)$ & EMAC \\
\hline GEOSCCM & v3 & $\begin{array}{l}\text { Molod et al. }(2012,2015) \text {, } \\
\text { Oman et al. }(2011,2013)\end{array}$ & GEOSCCM \\
\hline GFDL-AM3 & v3 & $\begin{array}{l}\text { Donner et al. }(2011) \text {, } \\
\text { Lin et al. }(2014,2015 a, b)\end{array}$ & AMTRAC3 \\
\hline GFDL-CM3 & v3 (CMIP5) & $\begin{array}{l}\text { Griffies et al. (2011); John et al. (2012), } \\
\text { Levy II et al. (2013) }\end{array}$ & AMTRAC3 \\
\hline HadGEM3-ES & $\begin{array}{l}\text { HadGEM3 GA4.0, } \\
\text { NEMO 3.4, CICE, } \\
\text { UKCA, MetUM } 8.2\end{array}$ & $\begin{array}{l}\text { Walters et al. (2014); Madec (2008), } \\
\text { Hunke and Lipscombe (2008); Morgenstern et al. (2009), } \\
\text { O'Connor et al. (2014); Hardiman et al. (2016), }\end{array}$ & $\begin{array}{l}\text { UMUKCA-METO } \\
\text { (MetUM 6.1) }\end{array}$ \\
\hline $\begin{array}{l}\text { LMDz-REPROBUS- } \\
\text { CM5 \& CM6 }\end{array}$ & IPSL-CM5 \& CM6 & $\begin{array}{l}\text { Marchand et al. (2012); Szopa et al. (2012), } \\
\text { Dufresne et al. (2013). } \\
\text { No reference yet on CM6 }\end{array}$ & LMDZrepro \\
\hline MRI-ESM1r1 & v1.1 & $\begin{array}{l}\text { Yukimoto et al. (2012, 2011), } \\
\text { Deushi and Shibata }(2011)\end{array}$ & MRI \\
\hline MOCAGE & $\mathrm{v} 2.15 .1$ & Josse et al. (2004); Guth et al. (2016) & N/A \\
\hline SOCOL & v3 & $\begin{array}{l}\text { Revell et al. (2015), } \\
\text { Stenke et al. (2013) }\end{array}$ & $\begin{array}{l}\text { SOCOL v2.0 } \\
\text { (Schraner et al., 2008) }\end{array}$ \\
\hline TOMCAT & v1.8 & Chipperfield $(1999,2006)$ & N/A \\
\hline ULAQ-CCM & v3, yr 2012 & Pitari et al. (2014) & ULAQ \\
\hline UMSLIMCAT & v1 & Tian and Chipperfield (2005) & UMSLIMCAT \\
\hline UMUKCA-UCAM & MetUM 7.3 & $\begin{array}{l}\text { Morgenstern et al. (2009), } \\
\text { Bednarz et al. (2016) }\end{array}$ & $\begin{array}{l}\text { UMUKCA-UCAM } \\
\text { (MetUM 6.1) }\end{array}$ \\
\hline
\end{tabular}

for different processes (Table S6). In addition, most models now use the Gregorian or the 365-day calendars (whereas in CCMVal-2, for reasons of easier handling of averages and climatologies, often a 360-day calendar was used). Only the Met Office Unified Model (MetUM)-based models (ACCESS CCM, HadGEM3-ES, NIWA-UKCA, UMSLIMCAT, UMUKCA-UCAM) and ULAQ still use the 360-day calendar.

\subsection{Horizontal diffusion}

Numerical diffusion relates to the impossibility to represent transport in an exact manner on a discrete grid. Errors occurring in such a process can usually be described as an unphysical, numerical diffusion process. It is an unavoidable aspect of numerical climate models. Transport schemes are generally designed to minimize numerical diffusion. However, in addition, several models require explicit diffusion for stability (Table S7). In CESM1 CAM4-chem 
Table 3. Governing equations, horizontal discretization, and vertical grid of the atmosphere component of models. NH is non-hydrostatic; PE is primitive equations; QG is quasi-geostrophic; $\mathrm{F}[\mathrm{D}, \mathrm{V}] \mathrm{LL}$ is finite [difference, volume] on lat-long grid; STQ is spectral transform quadratic; STL is spectral transform linear; CP is Charney-Phillips; TA is hybrid terrain-following altitude; TP is hybrid terrain-following pressure; NTP is non-terrain-following pressure; FVCS is finite volume cubed sphere; T21 $\approx 5.6^{\circ} \times 5.6^{\circ} ; \mathrm{T} 42 \approx 2.8^{\circ} \times 2.8^{\circ}$; $\mathrm{T} 47 \approx 2.5^{\circ} \times 2.5^{\circ}$; $\mathrm{T} 63 \approx 1.9^{\circ} \times 1.9^{\circ} ; \mathrm{TL} 159 \approx 1.125^{\circ} \times 1.125^{\circ}$.

\begin{tabular}{|c|c|c|c|c|c|c|c|c|}
\hline Model name & Gov. eq. & Hor. disc. & Resolution & Vert. grid & Top level & Top of model & Coord. sys. & Comment \\
\hline \multicolumn{9}{|l|}{ ACCESS CCM } \\
\hline NIWA-UKCA & $\mathrm{NH}$ & FDLL & $3.75^{\circ} \times 2.5^{\circ}$ & CP60 & $84 \mathrm{~km}$ & $84 \mathrm{~km}$ & TA & Arakawa-C \\
\hline \multicolumn{9}{|l|}{ UMUKCA-UCAM } \\
\hline CCSRNIES MIROC3.2 & PE & STQ & $\mathrm{T} 42$ & L34 & $1.2 \mathrm{~Pa}$ & $1 \mathrm{~Pa}$ & $\mathrm{TP}$ & \\
\hline CHASER (MIROC-ESM) & $\mathrm{PE}$ & STQ & $\mathrm{T} 42$ & L57 & $56 \mathrm{~km}$ & $56 \mathrm{~km}$ & $\mathrm{TP}$ & Arakawa-C \\
\hline CESM1 CAM4-chem & $\mathrm{PE}$ & FVLL & $1.9^{\circ} \times 2.5^{\circ}$ & $\mathrm{L} 26 / 56$ & $200 \mathrm{~Pa}$ & $100 \mathrm{~Pa}$ & $\mathrm{TP}$ & Lin (2004) \\
\hline CESM1 WACCM & $\mathrm{PE}$ & FVLL & $1.9^{\circ} \times 2.5^{\circ}$ & L66/88 & $140 \mathrm{~km}$ & $140 \mathrm{~km}$ & $\mathrm{TP}$ & Lin $(2004)$ \\
\hline CMAM & $\mathrm{PE}$ & STL & $\mathrm{T} 47$ & L71 & $0.08 \mathrm{~Pa}$ & $0.0575 \mathrm{~Pa}$ & $\mathrm{TP}$ & \\
\hline CNRM-CM5-3 & $\mathrm{PE}$ & STL & T63 & L60/89 & $7 / 8 \mathrm{~Pa}$ & $0 \mathrm{~Pa}$ & $\mathrm{TP}$ & \\
\hline EMAC & $\mathrm{PE}$ & STQ & $\mathrm{T} 42$ & L47/90 & $1 \mathrm{~Pa}$ & $0 \mathrm{~Pa}$ & $\mathrm{TP}$ & \\
\hline GEOSCCM & $\mathrm{PE}$ & FVCS & $\sim 2^{\circ} \times 2^{\circ}$ & L72 & $1.5 \mathrm{~Pa}$ & $1 \mathrm{~Pa}$ & $\mathrm{TP}$ & \\
\hline GFDL-AM3/CM3 & $\mathrm{NH}$ & FVCS & $\sim 2^{\circ} \times 2^{\circ}$ & L48 & $86 \mathrm{~km}$ & $86 \mathrm{~km}$ & $\mathrm{TA}$ & $\begin{array}{l}\text { Donner et al. } \\
\text { (2011) }\end{array}$ \\
\hline HadGEM3-ES & $\mathrm{NH}$ & FDLL & $1.875^{\circ} \times 1.25^{\circ}$ & CP85 & $85 \mathrm{~km}$ & $85 \mathrm{~km}$ & $\mathrm{TA}$ & Arakawa-C \\
\hline MRI-ESM1r1 & $\mathrm{PE}$ & STL & TL159 & L80 & $1 \mathrm{~Pa}$ & $0 \mathrm{~Pa}$ & $\mathrm{TP}$ & \\
\hline LMDz-REPROBUS & $\mathrm{PE}$ & FVLL & $3.75^{\circ} \times 2.5^{\circ}$ & $\mathrm{L} 39 / 79$ & $\sim 70 / 80 \mathrm{~km}$ & $\sim 70 / 80 \mathrm{~km}$ & $\mathrm{TA}$ & Arakawa-C \\
\hline MOCAGE & CTM & FDLL & $2^{\circ} \times 2^{\circ}$ & L47 & $500 \mathrm{~Pa}$ & $500 \mathrm{~Pa}$ & $\mathrm{TP}$ & \\
\hline SOCOL & $\mathrm{PE}$ & STL & $\mathrm{T} 42$ & L39 & $1 \mathrm{~Pa}$ & $0 \mathrm{~Pa}$ & $\mathrm{TP}$ & \\
\hline TOMCAT & CTM & FVLL & $2.8^{\circ} \times 2.8^{\circ}$ & L60 & $10 \mathrm{~Pa}$ & $0 \mathrm{~Pa}$ & $\mathrm{TP}$ & ERA-Interim \\
\hline ULAQ CCM & QG & STL & $\mathrm{T} 21$ & CP126 & $4 \mathrm{~Pa}$ & $4 \mathrm{~Pa}$ & NTP & \\
\hline UMSLIMCAT & $\mathrm{PE}$ & FDLL & $3.75^{\circ} \times 2.5^{\circ}$ & L64 & $1 \mathrm{~Pa}$ & $0.77 \mathrm{~Pa}$ & $\mathrm{TP}$ & Arakawa-B \\
\hline
\end{tabular}

and CESM1 WACCM, hyperdiffusion is applied to the smallest scales, and through Fourier transformation and filtering the effective resolution is kept the same at all latitudes. Several models (ACCESS CCM, NIWA-UKCA, UMUKCAUCAM, GEOSCCM, HadGEM3-ES, LMDz-REPROBUS, MOCAGE) do not contain explicit diffusion in most of their domains. "Sponges" are generally used to prevent reflection of planetary or Rossby waves off the model top, except for CMAM, the MRI ESM, and HadGEM3-ES. The MetUM family of models also requires diffusion over the poles (ACCESS CCM, NIWA-UKCA, UMUKCA-UCAM, HadGEM3-ES). The need for polar filtering should disappear with the future adoption of "novel" grids that no longer have any singularities at the poles.

\subsection{Quasi-biennial oscillation}

Essentially, the same CCMs that used nudging for CCMVal2 continue to use nudging to impose a quasi-biennial oscillation (QBO) in their models. However, nudging is performed in a more sophisticated way, with SOCOL, CCSRNIES MIROC3.2, and EMAC now using smooth transitions at the edges of the nudged region (Table S8). Other models do not impose a QBO (except for the specifieddynamics simulations). This means that the QBO is either occurring spontaneously in these models (validating this and other aspects of model behaviour is beyond the scope of this paper), or it is simply absent.

\subsection{Orographic and non-orographic gravity wave drag}

Gravity waves are the result of vertical displacements of air in the presence of stratification, which can be due, e.g., to mountains, frontal systems, or tropospheric convective activity. They can either be dissipated if they encounter critical levels (at which the phase speed equals the background winds), or they continue to propagate upwards and increase in amplitude, in accordance with the decreasing air density. Eventually they can break, leading to deceleration of the mean flow. This process contributes to the driving of the stratospheric Brewer-Dobson Circulation, but also affects the temperature structure of the middle atmosphere. Their horizontal scale is mostly below the grid scale, meaning that this process needs to be parameterized. Gravity waves are also poorly observed, contributing to a substantial diversity of approaches to representing this process (Table S9). The paucity of observations leads to gravity wave drag being often used to tune better known model diagnostics such as stratospheric temperatures or age of air.

Gravity wave drag (GWD) is usually divided into two components for modelling: orographic and non-orographic drag. The representation of orographic drag is based on the interaction of flow with topography, a relatively wellknown process. Non-orographic gravity waves by contrast are geographically poorly constrained; therefore, often relatively simple approaches, not taking into account any tropospheric meteorology, are used. However, in contrast to 
CCMVal-2, several models now link non-orographic drag to tropospheric processes such as convection (CNRM-CM5-3, CESM1 WACCM). This means that in these models, possible changes in the GWD sources associated with climate change are represented.

\subsection{Physical parameterizations}

References for the descriptions of the models' physical parameterizations such as turbulent vertical fluxes and dry convection, moist convection, cloud microphysics, aerosol microphysics, and cloud cover can be found in Tables S10 and S11. Several models have renewed their physics parameterizations since CCMVal-2, namely ACCESS CCM, NIWAUKCA, CNRM-CM5-3, GFDL-CM3/AM3, HadGEM3-ES, LMDz-REPROBUS, MRI-ESM, SOCOL, and UMUKCAUCAM.

\subsection{Cloud microphysics}

Clouds remain a very substantial source of uncertainty and inter-model differences, e. g. regarding climate sensitivity (for a summary of current understanding see chapter 7 of IPCC, 2013). Small-scale variability, non-equilibrium processes, cloud-aerosol interactions, and other processes all contribute to this. The CCMI-1 model ensemble is characterized by some considerable diversity in approaches to cloud microphysics (Table S12), and most models have implemented changes in the way clouds are represented, relative to CCMVal-2 (where clouds never were a particular focus).

\subsection{Tropospheric chemistry}

In contrast to CCMVal-2 (which did not focus on tropospheric chemistry), a majority of CCMI-1 models now explicitly represent tropospheric ozone chemistry (Table S13). Six models do not represent any non-methane hydrocarbon (NMHC) chemistry (CCSRNIES MIROC3.2, CMAM, CNRM-CM5-3, LMDz-REPROBUS, TOMCAT, UMSLIMCAT). In LMDz-REPROBUS, a climatological, zonally invariant tropospheric composition is prescribed below $400 \mathrm{hPa}$. Unlike stratospheric chemistry, tropospheric chemistry is too complex to be incorporated comprehensively in a CCM. The need to include an affordable yet skilled tropospheric chemistry scheme drives some diversity in the chemistry schemes and correspondingly the represented NMHC source gases. Several schemes use lumping, whereby emissions of a non-represented NMHC source gas are implemented as emissions of a represented one. Sometimes this species is denoted as "a lumped species" or "OTHC" (other carbon; Table S15). SOCOL has the simplest organic chemistry scheme in the ensemble (the only organic NMHC source gas, disregarding $\mathrm{HCHO}$, is isoprene, $\mathrm{C}_{5} \mathrm{H}_{8}$ ). By contrast, the CTM MOCAGE and several CCMs represent 10 or more NMHC source gases.
For methane $\left(\mathrm{CH}_{4}\right)$ the recommendation is to use a single prescribed time-evolving volume-mixing ratio (as defined by the Representative Concentration Pathway (RCP 6.0); Meinshausen et al., 2011) as the global lower boundary condition. This is followed by almost all models. CHASER has an interactive methane scheme, and the EMAC and ULAQ models prescribe $\mathrm{CH}_{4}$ mixing ratios at the surface under consideration of a hemispheric asymmetry (i.e. there is about $5 \%$ less $\mathrm{CH}_{4}$ in the Southern than in the Northern Hemisphere). EMAC also prescribes a seasonal cycle for $\mathrm{CH}_{4}$.

\subsection{Stratospheric chemistry}

Stratospheric gas-phase chemistry is well-enough understood and sufficiently simple so that it can be treated mostly explicitly, by adopting all relevant reactions for which rate coefficients have been published. Most models follow the Sander et al. (2011b) recommended rates. There is some diversity as to which halogen source gases are considered (Table S13). Six models represented here also participated in the re-assessment of lifetimes of long-lived species (SPARC, 2013). In this context, UMUKCA-UCAM and CESM1 WACCM have expanded their range of halogen source gases, relative to CCMVal-2. Most MetUMbased participants (ACCESS CCM, HadGEM3-ES, NIWAUKCA, UMSLIMCAT) continue to lump chlorine source gases, which are dominated by chlorofluorocarbons (CFCs), into only two representatives (CFC-11, CFC-12; Morgenstern et al., 2009). SOCOL and the CESM model family, at 14 and 12 species including Halon-1211, respectively, have the largest number of chlorine source gases. For bromine, the recommendation was to include the shortlived constituents di-bromomethane $\left(\mathrm{CH}_{2} \mathrm{Br}_{2}\right)$ and bromoform $\left(\mathrm{CHBr}_{3}\right.$; Eyring et al., 2013a); about half of the models follow this recommendation. All models represent $\mathrm{CH}_{3} \mathrm{Br}$ (the most abundant bromine source gas); several also include Halon-1211, Halon-1301, and/or Halon-2402. $\mathrm{CH}_{3} \mathrm{Br}$ in some cases is lumped with other bromine sources gases not represented (ACCESS CCM, HadGEM3-ES, NIWA-UKCA, UMSLIMCAT). EMAC also has a representation of a sea salt aerosol source of gas-phase halogen, which may be of importance to the tropospheric oxidizing capacity (Allen et al., 2007), and a larger range of very short-lived organic bromine compounds, which likely influence tropospheric and stratospheric ozone chemistry. There do not appear to be fundamental differences with respect to how stratospheric chemistry was treated for CCMVal-2. For example, all models have an explicit representation of methane oxidation to produce stratospheric water vapour that is based on similar reactions and rates. CESM1 WACCM, which covers the upper atmosphere, explicitly treats ion/neutral chemistry important in that region. Other than that, there appears to be no significant characteristic of the formulation of stratospheric chemistry that would, e.g., distinguish low-top from high-top models. Morgenstern et al. (2010) provided a more exhaustive dis- 
cussion of stratospheric chemistry in CCMVal-2 models that is still generally relevant.

\subsection{Stratospheric and tropospheric heterogeneous chemistry}

Heterogeneous chemistry (i.e. reactions that require a solid or liquid surface as a catalyst) is crucial to several aspects of atmospheric chemistry, notably the ozone hole and the tropospheric nitrogen cycle. Most of the reactions in Table S17 are chlorine and/or bromine activation reactions, e.g. they turn chlorine from its unreactive forms $\left(\mathrm{HCl}, \mathrm{ClONO}_{2}\right)$ into reactive forms (that photolyse readily in sunlight). The implementation of heterogeneous chemistry is subject to considerable inter-model differences regarding represented reactions and their associated heterogeneous surface types. Seven models (CCSRNIES MIROC3.2, CESM1 CAM4-chem, CESM1 WACCM, CHASER, CMAM, GFDL CM3/AM3, and MOCAGE) explicitly consider supercooled ternary solutions (STS; mixtures of $\mathrm{HNO}_{3}, \mathrm{H}_{2} \mathrm{SO}_{4}$, and $\mathrm{H}_{2} \mathrm{O}$ ) which impact stratospheric chemistry through swelling of droplets and associated denitrification and heterogeneous chemistry. Nitric acid formation (and subsequent nitrogen removal) partly occurs on/in cloud droplets, ice crystals, and on aerosol surfaces. Most models have nitric acid formation occurring on nitric acid trihydrate (NAT) and ice surfaces and also on sulfate aerosol (the details of which depend on how this aerosol is represented). In EMAC and MRI ESM1r1, this process also occurs on sea salt aerosol. Also $\mathrm{SO}_{2}$ oxidation to form $\mathrm{SO}_{3}$ (which then further reacts to form sulfate aerosol; the intermediates are often omitted in model formulations) partly occurs in the aqueous cloud phase. Most models include this heterogeneous reaction (Table S18). In several models (ACCESS CCM, CESM1 CAM4-chem, CESM1 WACCM, CHASER (MIROC ESM), GFDL-AM3/CM3, HadGEM3ES, MOCAGE, NIWA-UKCA, ULAQ, UMUKCA-UCAM) this process involves a gas-phase reaction with $\mathrm{OH}$ and aqueous-phase reactions with $\mathrm{O}_{3}$ and $\mathrm{H}_{2} \mathrm{O}_{2}$ (Feichter et al., 1996; Kreidenweis et al., 2003; Tie et al., 2005). EMAC treats $\mathrm{SO}_{2}$ oxidation as part of a complex gas- and aqueouschemistry mechanism detailed by Jöckel et al. (2016). ULAQ also has $\mathrm{SO}_{2}+\mathrm{H}_{2} \mathrm{O}_{2} \rightarrow \mathrm{SO}_{3}$ occurring on uppertropospheric ice particles (Clegg and Abbatt, 2001). In MRIESM1r1, $\mathrm{SO}_{2}$ reacts with gas-phase $\mathrm{OH}, \mathrm{O}_{3}$, and $\mathrm{O}\left({ }^{3} \mathrm{P}\right)$ to form $\mathrm{SO}_{3}$, with rates following Sander et al. (2011b). In all cases, the oxidants are calculated interactively.

\subsection{Polar stratospheric clouds (PSCs)}

Like for CCMVal-2, the models divide into two groups: those that assume thermodynamical equilibrium for PSCs (i.e. the gas-phase constituents are reduced to their saturation abundances and excess matter is condensed into PSCs), and others (CESM1, EMAC, GEOSCCM, ULAQ) that account for deviations from thermodynamic equilibrium (Ta- ble S19). Usually, at least two PSC types (type 1: nitric acid trihydrate; type 2: ice) as well as ubiquitous sulfate aerosol are assumed (Table S17). Several models also account for STS (i.e. $\mathrm{HNO}_{3}+\mathrm{H}_{2} \mathrm{SO}_{4}+\mathrm{H}_{2} \mathrm{O}$ mixtures). With the exception of CMAM, all models account for PSC sedimentation (which leads to denitrification) but assumptions around this vary considerably. Several models impose fixed sedimentation velocities for the different PSC types; in others, these velocities are a function of particle size. In most models, the approach to handling PSCs appears to be unchanged versus SPARC (2010).

\subsection{Tropospheric aerosol}

The additional focus, relative to CCMVal-2, on tropospheric climate-composition linkages has led to most models including an explicit treatment of tropospheric aerosol, except for CCSRNIES MIROC3.2, EMAC, CNRM-CM53, LMDz-REPROBUS, and SOCOL (Table S20). CMAM uses prescribed sulfate aerosol surface area densities in the troposphere for heterogeneous chemistry calculations. In CCMVal-2, most models did not have any representation of tropospheric aerosols.

Most aerosol schemes are "bulk", i.e. only total mass of an aerosol type is predicted. In bulk schemes, derived quantities such as particle number require assumptions about particle sizes to be made. The ULAQ CCM and MRI-ESM1r1 use sectional approaches, which represent aerosols of different size classes in discrete bins, thus avoiding a priori assumptions on particle size. The ULAQ CCM represents nitrate aerosol in a modal way; i.e. the aerosol size distribution is assumed to be described by one or more log-normal distributions. Modal schemes are computationally more efficient than sectional schemes while also predicting both aerosol size and number. Several models (CNRM-CM5-3, EMAC, SOCOL) use offline representations of aerosol. Types of aerosol included in the models comprise dust, sea salt, organic carbon, black carbon, sulfate, and nitrate (in the case of CHASER and ULAQ). These provide surfaces for heterogeneous chemistry (Table S18) but there appears to be little consistency regarding how this aspect is treated.

\subsection{Volcanic effects}

There has been considerable progress regarding the physical consistency of volcanic effects in CCMs. Whereas in CCMVal-2, surface area densities and aerosol-induced heating rates were prescribed; now 13 of the CCMI- 1 models treat radiative effects online, i.e. calculate or assume an aerosol size distribution for volcanic aerosol in the stratosphere and derive radiative heating rates from this (CCSRNIES MIROC3.2, CESM1 (both versions), CHASER, CMAM, CNRM-CM5-3, EMAC, GESCCM, HadGEM3ES, MRI ESM1r1, SOCOL, ULAQ CCM, UMUKCAUCAM; Table S21). GFDL-AM3/CM3 prescribes heat- 
ing rates associated with the presence of aerosol. The remaining models (ACCESS CCM, NIWA-UKCA, LMDzREPROBUS, UMSLIMCAT) do not consider stratospheric volcanic aerosol in their radiation schemes or do not have a radiation scheme (MOCAGE, TOMCAT). Surface area density used in heterogeneous chemistry calculations, with only two exceptions (GFDL-AM3/CM3, UMUKCAUCAM), follows the CCMI-1 recommendation (Sect. 4).

\subsection{Photolysis}

In CCMVal-2 and ACCMIP, in both cases half the models used tabulated photolysis rates and interpolation to calculate photolysis rates (Morgenstern et al., 2010; Lamarque et al., 2013). This approach is problematic in the troposphere because of complicating effects of clouds, aerosols, surface albedo, and other factors that are not considered in the precalculated tables. It is, however, computationally more efficient. With the new focus, relative to CCMVal-2, on tropospheric chemistry, all models that have explicit tropospheric chemistry also take explicit account of the presence of clouds (Table S22). GFDL-AM3 and the MetUM family (ACCESS CCM, HadGEM3-ES, NIWA-UKCA, UMUKCA-UCAM) have adopted the FAST-JX online formulation of photolysis in the domain (below $60 \mathrm{~km}$, in the case of the MetUM family), and a group of other models continue to use lookup tables but apply corrections accounting for the presence of clouds (CESM1 CAM4-chem, CESM1 WACCM, CMAM, MOCAGE, MRI-ESM1r1, SOCOL). Also in many cases photolysis cross sections have been updated, relative to CCMVal-2.

\subsection{Shortwave radiation}

In most cases, models are using the same basic schemes as documented in SPARC (2010, Table S23). (The CTMs do not have any explicit treatment of radiation.) However, ULAQ, MRI ESM1r1, the 79-level version of LMDz-REPROBUS, the GFDL models, EMAC, CNRM-CM5-3, CCSRNIES MIROC3.2, and SOCOL have all increased their spectral resolution versus their CCMVal-2 predecessors.

\subsection{Longwave radiation}

Longwave radiation is treated largely in the same way as documented in SPARC (2010). (Again, the CTMs do not represent this process.) However, again a few models (CNRMCM5-3, MRI-ESM1r1, SOCOL, ULAQ) have increased their spectral resolution versus their CCMVal-2 predecessors (Table S24).

\subsection{Solar forcing}

Interactions between the atmosphere and the Sun are considered in an increasingly consistent manner in CCMI-1 models (Tables S25 and S26). All models consider spectrally re- solved irradiance. In six models (CCSRNIES MIROC3.2, EMAC, HadGEM3-ES, MRI ESM1r1, SOCOL, and ULAQ CCM) photolysis and shortwave radiation are handled consistently; in particular, the solar cycle is handled consistently in both. In the remaining models, the shortwave radiation and photolysis schemes have not specifically been made consistent. SOCOL and the MRI ESM1r1 also consider proton ionization by solar particles. With the exceptions of ACCESS CCM, NIWA-UKCA, and GEOSCCM, all models listed in Table S21 consider solar variability.

\subsection{Ocean surface forcing}

For the atmosphere-only reference (REF-C1 and REFC1SD) and sensitivity (SEN-C1) simulations (Sect. 3), ocean surface forcing (sea surface temperatures, sea ice) need to be imposed (Eyring et al., 2013a). Most modelling groups used the Hadley Centre Ice and Sea Surface Temperature (HadISST) dataset (Rayner et al., 2003), as recommended. The LMDz-REPROBUS model uses the Atmosphere Model Intercomparison Project (AMIP) II dataset (http://www-pcmdi.llnl.gov/projects/amip/ AMIP2EXPDSN/BCS_OBS/amip2_bcs.htm; Table S27). For the atmosphere-ocean coupled reference (REF-C2) and sensitivity (SEN-C2) simulations (Sect. 3), those models that do not couple to an interactive ocean/sea ice module require climate model fields to be imposed. A substantial variety of different climate model datasets were used for this purpose. In the ULAQ CCM simulations, an ocean surface dataset was used that was derived from a climate model simulation, with mean biases relative to HadISST removed.

\subsection{Ocean coupling}

Nine of the CCMI-1 models are coupled, at least for some simulations, to an interactive ocean module (Tables S1 and S28), namely CESM1 CAM4-chem, CESM1 WACCM, CHASER, EMAC, GFDL-CM3, HadGEM3-ES, LMDzREPROPUS-CM6, MRI-ESM 1r1, and NIWA-UKCA. This is a substantial increase from CCMVal-2 and ACCMIP, when only one model each (CMAM and GISS-E2-R) was coupled to an ocean/sea ice model (Morgenstern et al., 2010; Lamarque et al., 2013). These models therefore self-consistently represent climate change throughout the atmosphere and ocean domains, in contrast to atmosphere-only models where oceanic feedbacks are not considered. Three of the models (HadGEM3-ES, LMDz-REPROBUS-CM6, NIWA-UKCA) use versions of the NEMO ocean model (Madec, 2008). The other five use independent ocean models. For sea ice, apart from HadGEM3-ES and NIWA-UKCA, which use versions of CICE, all of the model use different sea ice modules. The coupling between the atmosphere, ocean, and sea ice modules involves the passing of several physical fields that define the interactions between these modules, which essentially consist of transfers of momentum, heat, moisture, and 
salinity. The coupling frequency also varies a lot, from daily to hourly.

\subsection{Land surface, soil, and the planetary boundary layer}

Land surface properties, such as vegetation and soil type, but also soil moisture, snow, and groundwater have significant climate effects (e.g. influence the severity of droughts and floods), mediated through surface albedo and evapotranspiration (IPCC, 2013). Hence, their representation in climate models is essential especially for regional climate simulations. CCMI-1 models, like IPCC-type climate models, generally have land surface schemes. Like for cloud microphysics, there is some considerable diversity of approaches in treating these three aspects of the models (Table S29).

\section{CCMI-1 simulations}

In this section, we briefly describe the motivation and some technical details regarding the experiments conducted for CCMI-1. Eyring et al. (2013a) have given more details. The specific forcings imposed are discussed briefly in Sect. 4 .

- REF-C1: this experiment is analogous to the REF-B1 experiment of CCMVal-2. Using state-of-knowledge historic forcings and observed sea surface conditions, the models simulate the recent past (1960-2010). The models are free-running.

- REF-C1SD: this is similar to REF-C1 but the models are nudged towards reanalysis datasets, and correspondingly the simulations only cover 1980-2010. ("SD" stands for specified dynamics.) Through a comparison to the REF-C1 simulations, the influence on composition of dynamical biases and differences in variability between the reanalysis and the models can be assessed. This type of experiment had not been conducted for CCMVal-2. Table S27 has details on how nudging is implemented in those models that have conducted the specified-dynamics simulations.

- REF-C2: this experiment is a set of seamless simulations spanning the period 1960-2100, similar to the REF-B2 experiment for CCMVal-2. The experiments follow the WMO (2011) A1 scenario for ozonedepleting substances and the RCP 6.0 (Meinshausen et al., 2011) for other greenhouse gases, tropospheric ozone $\left(\mathrm{O}_{3}\right)$ precursors, and aerosol and aerosol precursor emissions. Ocean conditions can either be taken from a separate climate model simulation, or the models can be coupled interactively to ocean and sea ice modules.

In addition to these reference simulations, a variety of sensitivity simulations have been asked for, which are variants on the reference simulations, typically with just one aspect changed.

- SEN-C2-fODS/SEN-C2-fODS2000: this is the same as REF-C2 but with ozone-depleting (halogenated) substances (ODSs) fixed at their 1960 or 2000 levels, respectively. The SEN-C2-fODS2000 simulations start in 2000, with ODS surface-mixing ratios fixed at their year-2000 values.

- SEN-C2-fGHG: this is similar to REF-C2 but with greenhouse gasses (GHGs) fixed at their 1960 levels, and sea surface and sea ice conditions prescribed as the 1955-1964 average (where these conditions are imposed).

- SEN-C2-fCH4: this experiment is identical to REF-C2 but the methane surface-mixing ratio is fixed to its 1960 value (Hegglin et al., 2016).

- SEN-C2-CH4rcp85: this experiment is identical to REF-C2 but the methane surface-mixing ratio follows the RCP 8.5 scenario, which anticipates a much larger increase in $\mathrm{CH}_{4}$ than RCP 6.0, approaching $3.8 \mathrm{ppmv}$ in 2100. All other GHGs and forcings follow RCP 6.0. The simulation covers 2005-2100.

- SEN-C2-fN2O: this experiment is identical to REF-C2 but the nitrous oxide surface-mixing ratio is fixed to its 1960 value (Hegglin et al., 2016).

- SEN-C1-fEmis/SEN-C1SD-fEmis: in these experiments, for species with explicit surface emissions such as nitrogen oxides $\left(\mathrm{NO}_{x}\right)$, carbon monoxide (CO), non-methane volatile organic compounds (NMVOCs), and aerosol precursors, 1960 emissions are prescribed throughout, allowing the role of meteorological variability in influencing tropospheric composition to be established.

- SEN-C2-fEmis: this is similar to REF-C2 but with surface and aircraft emissions fixed to their respective 1960 levels.

- SEN-C1-Emis/SEN-C1SD-Emis: in these experiments the recommended emission dataset is replaced with an emission dataset of the modellers' choice, to assess the impact of alternative emissions on tropospheric composition.

- SEN-C2-RCP: this is the same as REF-C2, but with the GHG scenario changed to either RCP 2.6, 4.5, or RCP 8.5. The simulations start in 2000. This means these scenarios differ in their assumptions on GHGs and surface emissions (but not regarding the ODSs). They also require adequate sea surface and sea ice conditions corresponding to the variant climate scenarios, for the atmosphere-only models. 
- SEN-C2-GeoMIP: these simulations link CCMI-1 with the Geoengineering Model Intercomparison Project (GeoMIP; Tilmes, 2015a). They are designed to test the impact of proposed efforts to actively manage the Earth's radiation budget to offset the impact of increasing GHGs using sulfur injections.

- SEN-C1-SSI: this is the same as REF-C1 but using a solar forcing dataset with increased UV intensity. (Krivova et al., 2006). (SSI stands for "spectral solar irradiance".)

- SEN-C2-SolarTrend: this experiment will assess the impact of a possible reduction of solar activity akin to the Maunder Minimum of the 17th and 18th centuries. It is anticipated that the Sun will move out of the recent grand maximum; this would perhaps counteract some anticipated global warming. More details on this experiment are at http://sparcsolaris.gfz-potsdam.de/input_ data.php.

\section{Forcings used in the reference simulations}

Eyring et al. (2013a) and Hegglin et al. (2016) provide full details of the forcings to be used in the above listed CCMI-1 simulations. Here we only comment on selected aspects.

\subsection{Greenhouse gases}

Most simulations use historical and/or RCP 6.0 mixing ratios for GHGs (Fig. 1a). These are characterized by continuing increases of carbon dioxide $\left(\mathrm{CO}_{2}\right)$, which more than doubles between 1960 and 2100 . However, the rate of increase reduces at the end of this period. The nitrous oxide $\left(\mathrm{N}_{2} \mathrm{O}\right)$ surface volume-mixing ratio (VMR) also increases continuously from around $290 \mathrm{ppbv}$ in 1960 to over $400 \mathrm{ppbv}$ in 2100 . The methane $\left(\mathrm{CH}_{4}\right)$ VMR increases during the 20th century, plateaus between around 2000 and 2030, and subsequently shows a renewed increase, a maximum in around 2070, and then a decrease in the last few decades of the 21 st century. In comparison to the REF-B2 simulations of CCMVal-2, $\mathrm{CO}_{2}$ and $\mathrm{N}_{2} \mathrm{O}$ follow similar projections, but $\mathrm{CH}_{4}$ has a considerably reduced maximum, which also occurs later in the $21 \mathrm{st}$ century (SPARC, 2010, Fig. 2.3).

\subsection{Ozone-depleting substances (ODSs)}

ODSs develop according to the A1 scenario of WMO (2011) (Fig. 1b). There are no major differences with respect to the scenario used by CCMVal-2 (SPARC, 2010, Fig. 2.3). The A1 scenario does not take into account the revised lifetimes of ODSs as documented in SPARC (2013). Test simulations with a scenario based on these revised lifetimes indicate that there would be no significant impact on ozone (WMO, 2015); hence, the recommendation for ODSs has
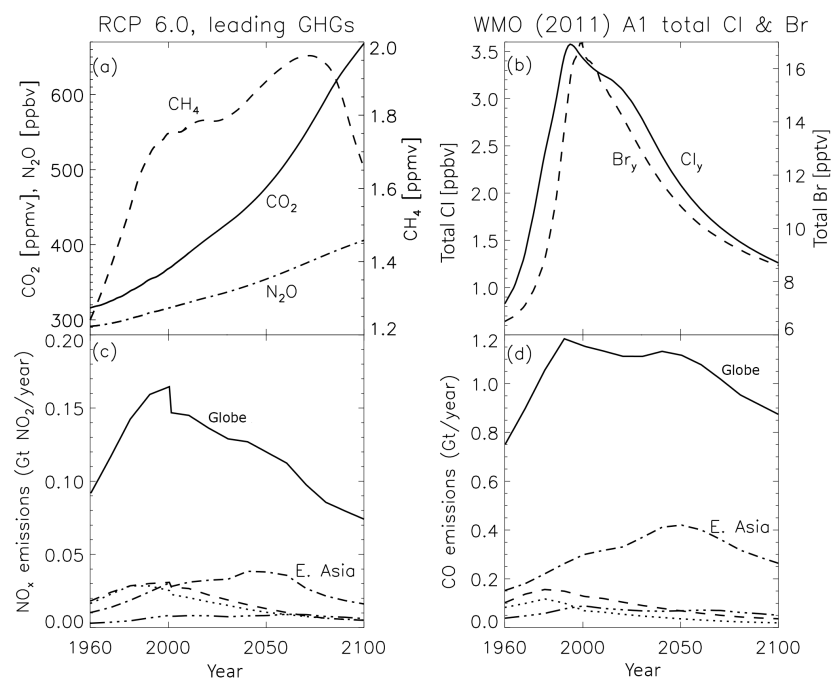

Figure 1. Selected forcings used in the REF-C2 simulations. (a) Carbon dioxide $\left(\mathrm{CO}_{2}\right.$; solid), methane $\left(\mathrm{CH}_{4}\right.$; dashed), and nitrous oxide $\left(\mathrm{N}_{2} \mathrm{O}\right.$; dash-dotted) surface mass-mixing ratios, following RCP 6.0 (Meinshausen et al., 2011). (b) Total chlorine $(\mathrm{Cl}$; solid) and total bromine (Br) excluding the mass-mixing ratios of the VSLSs (dashed; scenario A1 of WMO, 2011). (c) Total nitrogen oxide $\left(\mathrm{NO}_{x}\right)$ emissions. Solid: global; dashed: Europe; dotted: North America; dash-dotted: East Asia; dash-dot-dot-dotted: South Asia. (d) Same but for carbon monoxide (CO).

remained unchanged. In addition to long-lived ODSs, modellers are recommended to include $\mathrm{CH}_{2} \mathrm{Br}_{2}$ and $\mathrm{CHBr}_{3}$ as bromine source gases. Both are classified as very short-lived species (VSLSs). Surface-mixing ratios for both are fixed at $1.2 \mathrm{pptv}$ (giving a total of $6 \mathrm{pptv}$ of bromine). Considering losses of both species in the troposphere, they are meant to deliver the $\sim 5$ pptv of inorganic bromine to the stratosphere that is thought to originate as VSLSs (WMO, 2015).

\subsection{Anthropogenic tropospheric ozone and aerosol precursors}

For the REF-C2 scenario, for anthropogenic emissions the recommendation is to use MACCity (Granier et al., 2011) until 2000, followed by RCP 6.0 emissions. Figure 1c, d show globally and regionally integrated emissions of nitrogen oxides $\left(\mathrm{NO}_{x}\right)$ and carbon monoxide (CO). Globally, efforts to improve air quality, introduced during the late 20th century, cause past and projected future $\mathrm{NO}_{x}$ and $\mathrm{CO}$ emissions to peak and then decline. This is clearly seen in European and North American emissions (Fig. 2), but East and South Asian emissions are anticipated to continue to increase - East Asian emissions of $\mathrm{NO}_{x}$ only peak in around 2050 and remain substantial, compared to year-2000 emissions, until the end of this century. Notably, for $\mathrm{NO}_{x}$ there is a discontinuity in 2000 caused by differences in the assumptions on ship emissions between MACCity and RCP 6.0 (Fig. 2). For REF-C1, the MACCity emissions are used throughout the whole 1960- 
NO emissions, MACCity, 1960

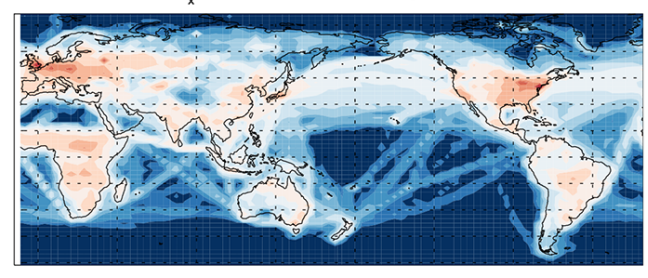

NO emissions, MACCity, 2000

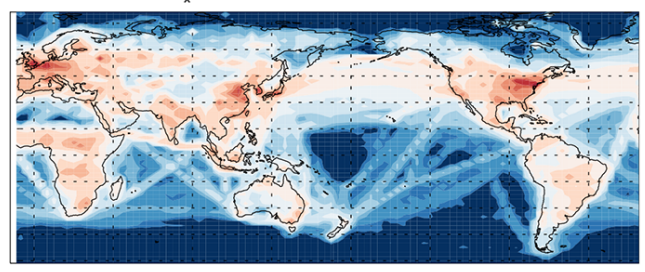

$\mathrm{NO}_{x}$ emissions, RCP 6.0, 2001

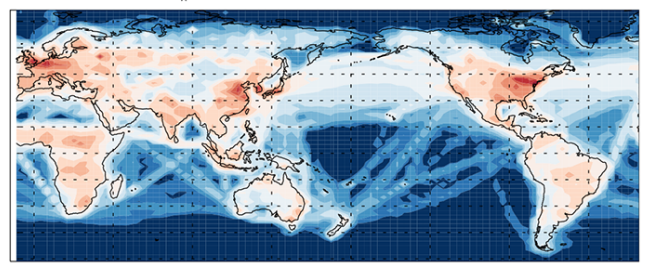

$\mathrm{NO}_{x}$ emissions, RCP 6.0, 2100

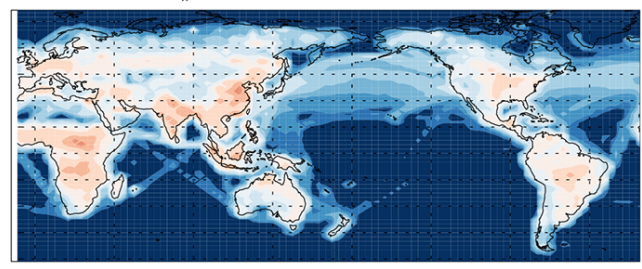

SO emissions, MACCity, 1960

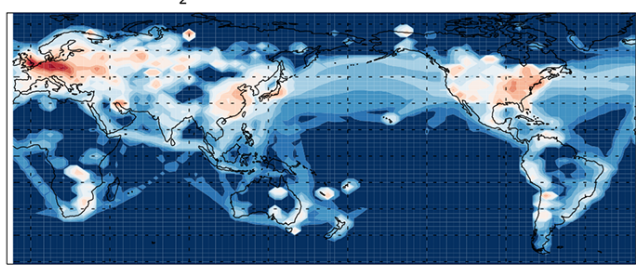

$\mathrm{SO}_{2}$ emissions, MACCity, 2000

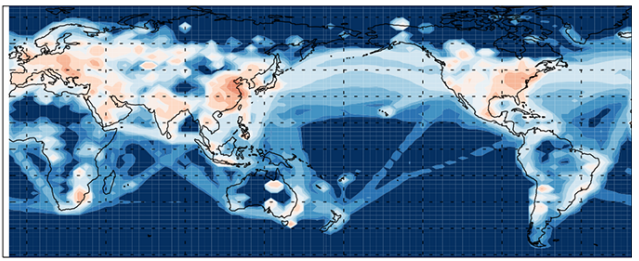

$\mathrm{SO}_{2}$ emissions, RCP 6.0, 2001

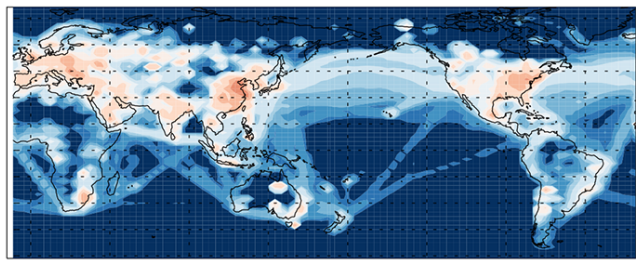

$\mathrm{SO}_{2}$ emissions, RCP $6.0,2100$

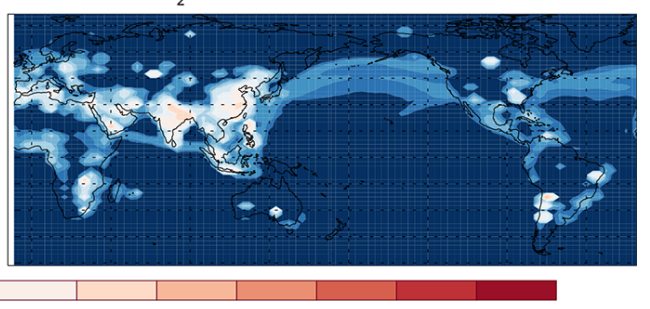

\section{$\begin{array}{lllllllllllllll}0 & .1 & .2 & .5 & 1 & 2 & 5 & 10 & 20 & 50 & 100 & 150 & 200 & 300 & 400\end{array}$}

Figure 2. (left) Annual-mean $\mathrm{NO}_{x}$ surface emissions $\left(10^{-12} \mathrm{~kg}\left(\mathrm{NO}_{2}\right) \mathrm{m}^{-2} \mathrm{~s}^{-1}\right)$ in 1960 and 2000, taken from the MACCity emissions database, and in 2001 and 2100, taken from RCP 6.0. (right) Same, but for $\mathrm{SO}_{2}$ in $\left(10^{-12} \mathrm{~kg}(\mathrm{~S}) \mathrm{m}^{-2} \mathrm{~s}^{-1}\right)$. Displayed here are the combined surface and stack-height emissions, excluding volcanic emissions.

2010 period covered. For $\mathrm{SO}_{2}$, between 1960 and 2000 European (and to a lesser extent North American) emissions drop considerably. This reflects efforts to improve air quality. This trend is anticipated to continue throughout the 21st century. By contrast, East Asian $\mathrm{SO}_{2}$ emissions increase somewhat during the 20th century. Asia dominates global industrial $\mathrm{SO}_{2}$ in 2100 , in the RCP 6.0 scenario. There is no discontinuity between MACCity and RCP 6.0 for $\mathrm{SO}_{2}$ emissions.

Whether or not non-represented NMVOCs are lumped with represented ones can result in differences in the actual amount of NMVOCs entering the troposphere (Sect. 2.10).

\subsection{Biogenic emissions}

For natural (biogenic) emissions, the CCMI-1 recommendation is to use interactive emissions, where available. The extent to which interactive schemes are used, however, is very species and model dependent, resulting in some diversity of choices regarding biogenic emissions. In the case of soil nitrogen oxide $\left(\mathrm{NO}_{x}\right)$ emissions, the majority of models uses prescribed emissions, with the exceptions of EMAC and GEOSCCM which both use the Yienger and Levy (1995) emissions scheme (Table S22). For oceanic dimethyl sulfide (DMS) emissions, most models use interactive emissions schemes with some commonality in the choice of scheme (e.g. Wanninkhof, 1992; Chin et al., 2002), particularly within model families, although a small number of models also use prescribed emissions for oceanic DMS. For biogenic acetone $\left(\left(\mathrm{CH}_{3}\right)_{2} \mathrm{CO}\right)$ emissions, all but the CESM1 models either exclude $\left(\mathrm{CH}_{3}\right)_{2} \mathrm{CO}$ or use prescribed emissions. CESM1 CAM4-chem and CESM1 WACCM, however, use the Model for Emissions of Gases and Aerosols from 


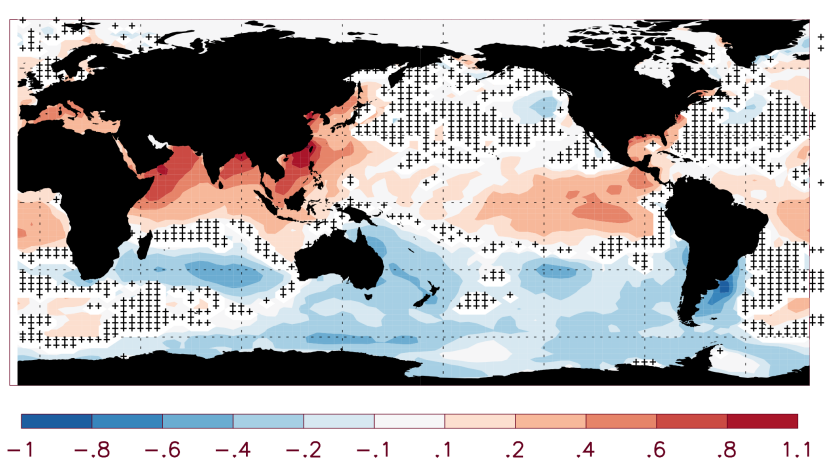

Figure 3. Trend in the annual-mean sea surface temperatures (SSTs), in HadISST for 1960-2010 (K century ${ }^{-1}$ ). Trends insignificant at $95 \%$ confidence are stippled.

Nature (MEGAN) 2.1 interactive scheme (http://lar.wsu.edu/ megan). For ethane $\left(\mathrm{C}_{2} \mathrm{H}_{6}\right)$, the CESM1 models also use MEGAN2.1, whereas all other models either exclude $\mathrm{C}_{2} \mathrm{H}_{6}$ altogether or prescribe emissions. For isoprene $\left(\mathrm{C}_{5} \mathrm{H}_{8}\right)$ emissions, about half of the models prescribe emissions and for those that use interactive terrestrial emissions, MEGAN is the predominant emissions scheme of choice. A small number of models include interactive oceanic $\mathrm{C}_{5} \mathrm{H}_{8}$ emissions. For species whose emissions are not modelled interactively, a variety of different assumptions have been made.

\subsection{Sea surface temperature and sea ice}

For the REF-C1 and SEN-C1 experiments, sea surface conditions need to be prescribed. For this, as for CCMVal2, the HadISST climatology (Rayner et al., 2003) is recommended (Sect. 2.20). Variance correction for this monthly mean climatology is recommended following the AMIP II method (http://www-pcmdi.llnl.gov/projects/amip/ AMIP2EXPDSN/BCS/bcsintro.php). Between 1960 and 2010 there is some warming in the HadISST dataset over various areas of the ocean, but also widespread cooling of the Southern Ocean (Fig. 3). Arctic annual minimum sea ice extent reduces considerably in this period, whereas Antarctic sea ice expands slightly (Fig. 4). HadISST is heavily based on satellite observations which are non-existent for the early part of the record, meaning that trends derived over this period have to be viewed with caution. For the REF-C2 and SEN-C2 experiments, either an interactive ocean/sea ice submodel is used or pre-calculated sea surface conditions derived from a variety of different climate model simulations as detailed in the previous paragraphs (Table S27).

\subsection{Stratospheric aerosol loading}

Figure 5 shows the aerosol surface area density at $22 \mathrm{~km}$ as recommended by CCMI- 1 and imposed by most models (Arfeuille et al., 2013). In comparison to the dataset used for CCMVal-2 (Morgenstern et al., 2010), the most signif-

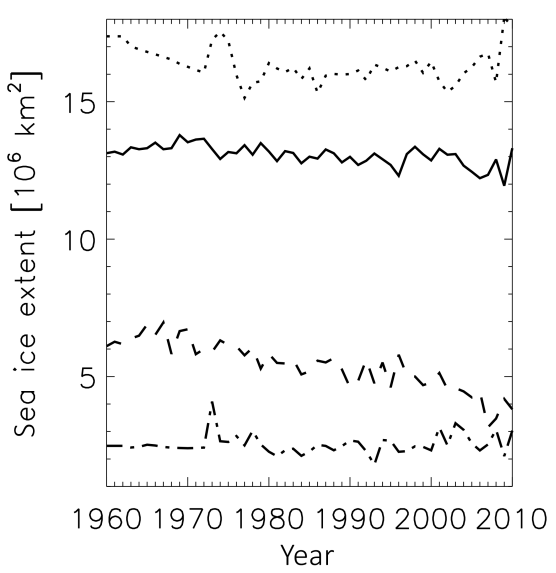

Figure 4. Maximum and minimum monthly mean sea ice extent in the HadISST climatology. Dotted: Antarctic maximum; solid: Arctic maximum; dashed: Arctic minimum; dot-dashed: Antarctic minimum.

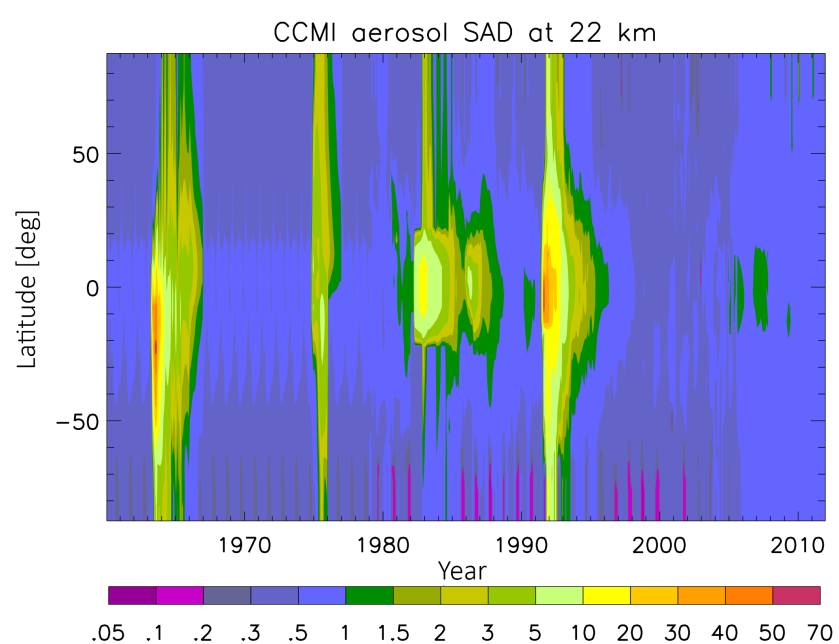

Figure 5. Zonal-mean aerosol surface area density $\left(\mu \mathrm{m}^{2} \mathrm{~cm}^{-3}\right)$ at $22 \mathrm{~km}$. The discrete events are due to volcanic eruptions, superimposed on a much smaller non-volcanic background.

icant difference is the insertion of a major volcanic injection of aerosol into the stratosphere in 1974/1975, due to the Fuego (Guatemala) eruption. This had been ignored before. Furthermore, note the increase in aerosol density during the last decade attributed to a series of small volcanic eruptions (Vernier et al., 2011).

\subsection{Solar forcing}

The recommended solar forcing dataset contains daily solar irradiance, ionization rates by solar protons, and the geomagnetic activity index $A_{\mathrm{p}}$ (http://solarisheppa.geomar.de/ccmi). Spectrally resolved solar irradiances for 1960-2010 were calculated with the empirical NRLSSI model (Lean et al., 2005). The spectral grid width ( $1 \mathrm{~nm}$ bins from 0 to $750 \mathrm{~nm}$, 

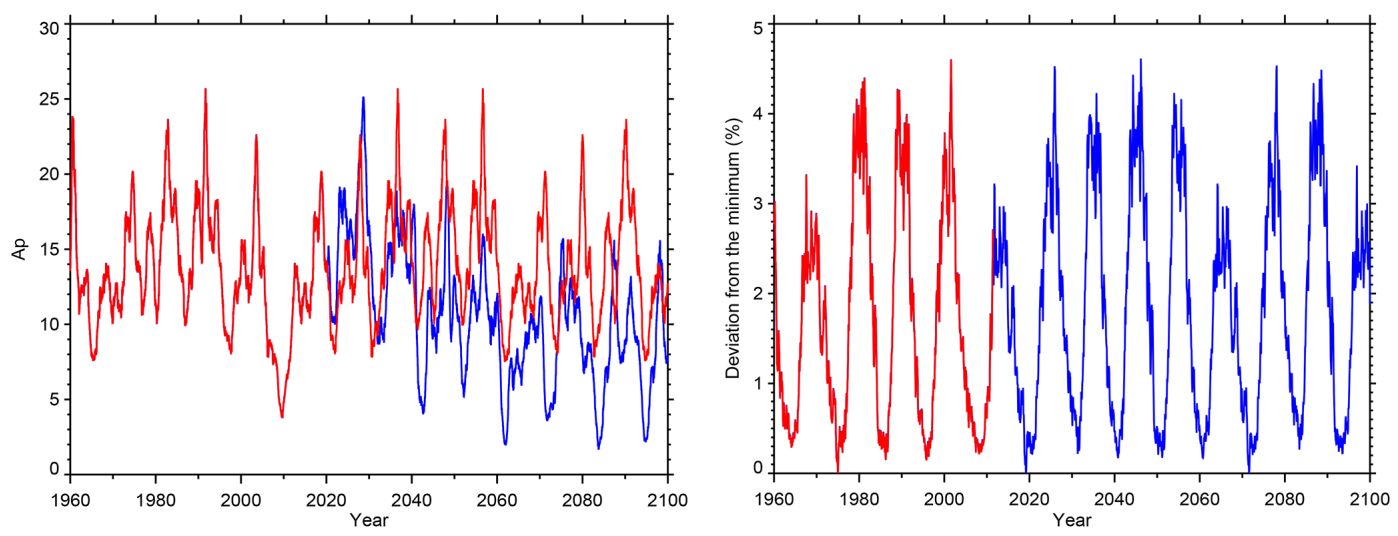

Figure 6. (left) Recommended $A_{\mathrm{p}}$ index time series for SEN-C2_SolarTrend (blue) and the other reference and sensitivity simulations (red). The data are smoothed with 360-day-wide window. (right) Deviation (\%) of the recommended monthly mean solar irradiance for the $175-250 \mathrm{~nm}$ spectral band from its minimum value, to be used in all simulations. Red: prior to and including 2010, the data are based on observations. Blue: projected solar irradiance post-2010.

$5 \mathrm{~nm}$ bins from $750 \mathrm{~nm}$ to $5 \mu \mathrm{m}, 10 \mathrm{~nm}$ bins from 5 to $10 \mu \mathrm{m}$, $50 \mathrm{~nm}$ bins from 10 to $100 \mu \mathrm{m}$ ) allows for easy calculations of the spectral SSI for any specific model spectral grids, which should be applied to calculate the shortwave heating rates in the radiation module and the photolysis in the chemistry scheme. The ionization rates caused by solar protons for the same time period are calculated using the Jackman et al. (2009) approach based on the proton flux measurements by several instruments onboard the GOES satellites. The recommended coefficients for the conversion of the ionization rates to in situ $\mathrm{HO}_{x}$ and $\mathrm{NO}_{x}$ production intensity are also given by Jackman et al. (2009). For the models extending only to the mesopause, a time-varying geomagnetic activity index $A_{\mathrm{p}}$ is provided as a proxy for the thermospheric $\mathrm{NO}_{x}$ influx, which is used to include indirect energetic particle effects using an approach similar to that defined by Baumgaertner et al. (2009). These datasets are recommended to be applied in REF-C1 simulations covering 1960-2010. For SENC1-SSI simulations, the SATIRE SSI dataset (Krivova et al., 2006) should be used instead of the NRLSSI data described above. This SSI dataset exhibits larger UV variability, which can have consequences not only for atmospheric heating but also for ozone chemistry (Ermolli et al., 2013). For REF-C2 simulations covering 2010-2100, it is recommended to repeat the SSI, solar proton event, and $A_{\mathrm{p}}$ sequences of the last four solar activity cycles (i.e. cycles 20-23). For the sensitivity experiment SEN-C2_SolarTrend covering 1960-2100, it is advised to introduce a declining trend in the solar activity, reflecting a widely discussed possible decline of solar activity in the future. The proposed trend is based on past solar activity cycles repeated in reverse order. Starting from 2011 it is recommended to apply daily SSI and particle output for the cycles $20,19,18,17,16,15,14,13$, and 12 . The programme to build daily future solar forcing for different experiments is available from http://solarisheppa.geomar.de/ccmi. Figure 6 illustrates the $A_{\mathrm{p}}$ index evolution for standard and sensitiv- ity scenarios, showing a decline of the geomagnetic activity in the future, and the recommended solar irradiance for the $175-250 \mathrm{~nm}$ spectral band from its minimum value.

\section{Availability of simulations}

Tables 4-6 summarize the available simulations at the time of writing this paper. As recommended, a large majority of models have performed the reference simulations. A subset has produced REF-C1SD, reflecting that not all models have the capability to be nudged to meteorological fields. The sensitivity simulations, both SEN-C1 and SEN-C2, are less consistently covered, ranging from 1 to 15 simulations.

Most of the model output can be accessed via the British Atmospheric Data Center (BADC), which hosts the CCMI-1 data archive. Some model institutions provide their data however directly via their local Earth System Grid Federation nodes (see the list provided on http://www.met.reading.ac. uk/ccmi/?page_id=251). CESM1 CAM4-chem and CESM1 WACCM data are provided via https://www.earthsystemgrid. org/search.html?Project=CCMI1. In some cases, the simulations are complete but have not or not fully been uploaded for public access. In these cases, readers are advised to contact the corresponding model PIs. In particular, for GFDL AM3/CM3 simulations, please contact Meiyun Lin (meiyun.lin@noaa.gov).

\section{Conclusions}

The purpose of this paper has been to provide some overview information on the internal make-up of CCMI-1 models, broadly characterize the forcings, and give an overview of available simulations under CCMI-1, mainly to inform authors of other papers focussing on scientific results of CCMI-1. We have not assessed model performance, but it 
Table 4. Numbers of reference simulations, by model. Numbers in brackets denote simulations that are incomplete at the time of publication. "L39" stands for the 39-level version of LMDz-REPROBUS.

\begin{tabular}{llll}
\hline Model name & $\begin{array}{l}\text { REF-C1 } \\
(1960-2010)\end{array}$ & $\begin{array}{l}\text { REF-C2 } \\
(1960-2100)\end{array}$ & $\begin{array}{l}\text { REF-C1SD } \\
(1980-2010)\end{array}$ \\
\hline ACCESS CCM & 1 & 2 & \\
CCSRNIES MIROC3.2 & 3 & 1 & 1 \\
CESM1 CAM4-chem & 3 & 3 & 1 (NASA MERRA) \\
CESM1 WACCM & 5 & 3 & 1 (NASA MERRA) \\
CHASER (MIROC-ESM) & 1 & 1 & \\
CMAM & 3 & 1 & 1 \\
CNRM-CM5-3 & 4 & 2 & 2 \\
EMAC & 2 & 3 & 4 \\
GEOSCCM & 1 & 1 & 1 \\
GFDL-AM3 & & & 1 (Lin et al., 2014) \\
GFDL-CM3 & & 5 & \\
HadGEM3-ES & 1 & $1(+2)$ & $(2)$ \\
LMDz-REPROBUS & $1($ L39) & $1($ L39) & 1 (L39) \\
MRI-ESM1r1 & 1 & 1 & 1 \\
MOCAGE & 1 & $(1)$ & 1 \\
NIWA-UKCA & 3 & 5 & \\
SOCOL & 4 & 1 & \\
TOMCAT & & & \\
ULAQ CCM & 3 & 3 & \\
UMSLIMCAT & 1 & 1 & 1 \\
UMUKCA-UCAM & 1 & 2 & \\
\hline Total & 39 & 38 & \\
\hline
\end{tabular}

Table 5. SEN-C1 sensitivity simulations, by model.

\begin{tabular}{|c|c|c|c|c|c|}
\hline Model name & SEN-C1-Emis & SEN-C1SD-Emis & SEN-C1-fEmis & SEN-C1SD-fEmis & SEN-C1-SSI \\
\hline CESM1 CAM4-chem & & & & 3 & \\
\hline CHASER (MIROC-ESM) & & & & 1 & \\
\hline GFDL-AM3 & 5 (Lin et al., 2014) & 1 & & 1 & \\
\hline MOCAGE & & & & 1 & \\
\hline NIWA-UKCA & & & 1 & & \\
\hline TOMCAT & & & & & 1 \\
\hline ULAQ CCM & & & 1 & & 3 \\
\hline UMSLIMCAT & 1 & & 1 & & 1 \\
\hline Total & 6 & 1 & 3 & 6 & 5 \\
\hline
\end{tabular}

Table 6. SEN-C2 sensitivity simulations, by model.

\begin{tabular}{|c|c|c|c|c|c|c|c|c|c|c|c|c|}
\hline Model name & $\mathrm{RCP} 2.6$ & $\mathrm{RCP} 4.5$ & RCP8.5 & fODS & fODS2000 & fGHG & fEmis & GeoMIP & SolarTrend & $\mathrm{fCH} 4$ & $\mathrm{fN} 2 \mathrm{O}$ & CH4rcp85 \\
\hline ACCESS CCM & & & & 2 & & 1 & & & & & & \\
\hline CCSRNIES MIROC3.2 & 1 & 1 & 1 & 1 & 1 & 1 & & & 1 & & & \\
\hline CESM1 CAM4-chem & & & & & & & & $3\left(1^{\circ}\right)$ & & & & \\
\hline CESM1 WACCM & & 1 & 3 & 3 & 3 & 3 & (1) & & & (1) & (1) & (1) \\
\hline CHASER (MIROC-ESM) & 1 & 1 & 1 & 1 & & 1 & 1 & (1) & & & & \\
\hline CMAM & 1 & 1 & 1 & 1 & & 1 & & & & 1 & 1 & (1) \\
\hline GFDL-CM3 & 1 & 3 & 1 & & & & & & & & & \\
\hline HadGEM3-ES & & & & & (3) & (3) & & & & & & \\
\hline LMDz-REPROBUS & 1 (L39) & 1 (L39) & 1 (L39) & 1 (L39) & 1 (L39) & 1 (L39) & & & & & & \\
\hline NIWA-UKCA & & & & 2 & & 3 & & & & (1) & (1) & \\
\hline SOCOL & 1 & 1 & 1 & & & & 1 & & & 1 & 1 & 1 \\
\hline ULAQ CCM & 1 & 1 & 1 & 1 & 1 & 1 & 2 & 2 & & (1) & (1) & \\
\hline Total & 7 & 10 & 10 & 12 & 9 & 15 & 5 & 6 & 4 & 5 & 5 & 3 \\
\hline
\end{tabular}


is clear from this paper that in the years since CCMVal2 and ACCMIP, considerable progress has been made to improve the models' internal consistency, make them more physically based, and more comprehensive, as well as improving their resolutions. While these developments have to be welcomed, experience shows that simulations with a more physically consistent and comprehensive model, which is less constrained by external forcings, may not compare more favourably against observations than those produced by a more constrained model (e.g. Eyring et al., 2013b). This is particularly the case as Earth System Models increasingly cover aspects of the climate system that are challenging to capture numerically, such as atmospheric chemistry or biogeochemistry of the ocean. This complicates measuring progress in climate modelling and contributes to the perceived "failure" of the climate modelling community to narrow the range of climate futures produced in multi-model inter-comparisons such as the 5th Coupled Model Intercomparison Project (CMIP5) or CCMI. Understanding how this diversity is linked to differences in model formulation can help explain such findings. The purpose of this paper, and a major motivation for CCMI, is to drive progress in this regard.

\section{Code and data availability}

Readers should contact the model PIs to enquire about conditions of code availability for the 20 models documented in this paper (Table 1).

No model output was used in this paper. For CCMI-1 model data, see Sect. 5. Forcing data used in this paper are described and can be downloaded at http://blogs.reading.ac. uk/ccmi/reference-simulations-and-forcings. 


\section{Appendix A: Individual model descriptions}

\section{A1 ACCESS-CCM and NIWA-UKCA}

NIWA-UKCA is a coupled atmosphere-ocean CCM, based on the HadGEM3-AO model (revision 2) coupled to the NIWA-UKCA gas-phase chemistry scheme. It is identical to ACCESS-CCM, except that ACCESS-CCM uses prescribed sea surface conditions in all simulations. Relative to the UMUKCA models used for CCMVal-2, both models now feature a medium-complexity tropospheric hydrocarbon oxidation scheme, including the Mainz Isoprene Mechanism (Pöschl et al., 2000) and the FAST-JX online photolysis scheme (Telford et al., 2013). NIWA-UKCA uses an interactive ocean and sea ice module (Hewitt et al., 2011). In transitioning to HadGEM3, atmospheric physics was updated; in particular, the models now use the PC2 cloud scheme (Wilson et al., 2008). The models are run at a resolution of N48L60 $\left(3.75^{\circ} \times 2.5^{\circ}\right)$ in the atmosphere and (for NIWAUKCA) $\sim 2^{\circ}$ and 31 levels in the ocean.

\section{A2 CCSRNIES MIROC3.2}

CCSRNIES MIROC3.2 CCM was constructed on the basis of the MIROC3.2 general circulation model (GCM), which was used for future climate projection in the 4th and 5th Assessment Reports of the Intergovernmental Panel on Climate Change (IPCC, 2007, 2013). The updated CCM introduces the stratospheric chemistry module of CCSRNIES CCM that was used for CCMVal-1 and CCMVal-2. CCSRNIES MIROC3.2 CCM has a new higher resolution radiation scheme for the spectral bins (32 bins) than that of CCSRNIES CCM (18 bins). The new CCM uses a semiLagrangian scheme for tracer transport, whilst CCSRNIES CCM used a spectral transport scheme. The new CCM is not coupled to the ocean; sea surface temperature (SST) and sea ice are prescribed in the simulations.

\section{A3 CESM1 CAM4-chem and CESM1 WACCM}

The Community Earth System Model, version 1 (CESM1) is a coupled climate model for simulating the Earth' climate system. The atmospheric component is the Community Atmosphere Model, version 4 (CAM4) (Neale et al., 2013), which uses a finite volume dynamical core (Lin, 2004) for the tracer advection. Two versions of CAM4 participated in CCMI-1: (1) a lower lid model reaching up to about $40 \mathrm{~km}$ altitude (CESM1 CAM4-chem); (2) and a high-top model that extends to approximately $140 \mathrm{~km}$ altitude (Whole Atmosphere Community Climate Model Version 4, CESM1 WACCM4). The horizontal resolution used for all CCMI-1 simulations is $1.9^{\circ} \times 2.5^{\circ}$ (latitude $\times$ longitude). Both model versions include detailed and identical representation of tropospheric and stratospheric (TS) chemistry and interactive tropospheric aerosols (Tilmes et al., 2016). The polar heterogeneous chemistry was recently updated (Wegner et al., 2013) and further evaluated by Solomon et al. (2015). CESM1 WACCM also includes a representation of physics and chemistry of the mesosphere-lower thermosphere (MLT) region (Marsh et al., 2013). The TS (CESM1 CAM4-chem) and TSMLT (CESM1 WACCM4) chemical mechanisms include 171 and 183 species, respectively, contained within the $\mathrm{O}_{x}, \mathrm{NO}_{x}, \mathrm{HO}_{x}, \mathrm{ClO}_{x}, \mathrm{BrO}_{x}$, and $\mathrm{FO}_{x}$ chemical families, along with $\mathrm{CH}_{4}$ and its degradation products. In addition, 17 primary non-methane hydrocarbons and related oxygenated organic compounds are included. All CCMI-1 scenarios use the same TS and TSMLT chemical mechanisms. The previous CCMVal-2 version of CESM1-WACCM simulated Southern Hemisphere winter and spring temperatures that were too cold compared with observations. Among other consequences, with the recent updates to the heterogeneous chemistry module, this "cold pole bias" leads to unrealistically low ozone column amounts in Antarctic spring. In all CCMI-1 simulations, the cold pole problem is addressed by introducing additional mechanical forcing of the circulation via parameterized gravity waves (Garcia et al., 2016).

\section{A4 CHASER (MIROC-ESM)}

The CHASER model (Sudo et al., 2002; Sudo and Akimoto, 2007), developed mainly at Nagoya University and the Japan Agency for Marine-Earth Science and Technology (JAMSTEC), is a coupled CCM, simulating atmospheric chemistry and aerosols. Aerosols are handled by the SPRINTARS module (Takemura et al., 2005). It has been developed also in the framework of the MIROC Earth System Model, MIROCESM-CHEM (Watanabe et al., 2010). CHASER simulates detailed chemistry in the troposphere and stratosphere with an online aerosol simulation including production of particulate nitrate and secondary organic aerosols. For this study, the model's horizontal resolution is selected to be T42 $\left(2.8^{\circ} \times\right.$ $2.8^{\circ}$ ) with 57 layers in the vertical extending from the surface up to about $55 \mathrm{~km}$ altitude. As for the overall model structure, CHASER is fully coupled with the climate model core MIROC, permitting atmospheric constituents (both gases and aerosols) to interact radiatively and hydrologically with meteorological fields in the model. The chemistry component of CHASER considers the $\mathrm{O}_{x}-\mathrm{NO}_{x}-\mathrm{HO}_{x}-\mathrm{CH}_{4}-\mathrm{CO}$ chemical system with oxidation of NMVOCs, halogen chemistry, and the $\mathrm{NH}_{x}-\mathrm{SO}_{x}-\mathrm{NO}_{3}$ system. In total 96 chemical species and 287 chemical reactions are considered. In the model, primary NMVOCs include $\mathrm{C}_{2} \mathrm{H}_{6}, \mathrm{C}_{2} \mathrm{H}_{4}, \mathrm{C}_{3} \mathrm{H}_{8}, \mathrm{C}_{3} \mathrm{H}_{6}, \mathrm{C}_{4} \mathrm{H}_{10}$, acetone, methanol, and biogenic NMVOCs (isoprene, terpenes).

\section{A5 CMAM}

Compared with the model version used for CCMVal-2, the CMAM used for the CCMI-1 simulations calculates chemistry throughout the troposphere, though the only hydrocarbon considered is methane. While CMAM was interactively coupled to an ocean model for CCMVal-2, specified SSTs 
and sea ice fields were used for all CCMI-1 simulations. The horizontal resolution has increased from T31 to T47 and while spectral advection is still used for all chemical tracers, for $\mathrm{HNO}_{3}$ and $\mathrm{NO}_{x}$ a logarithmic transformation of the mixing ratio (Scinocca et al., 2008) is advected to better preserve the strong horizontal gradients in the troposphere. For CCMVal-2 a constant dry deposition velocity was used to provide a tropospheric sink for selected species; here wet deposition is calculated interactively with the stratiform/deep convection parameterizations and dry deposition uses a "bigleaf" approach that is tied to the model land surface scheme. The look-up table for photolysis rates has been expanded to take account of surface albedo, and a correction to the clear-sky rates is made for clouds following the approach of Chang et al. (1987). Hydrolysis of $\mathrm{N}_{2} \mathrm{O}_{5}$ in the troposphere has been included, using a monthly varying climatology of sulfate aerosols from a more recent version of the Canadian climate model (von Salzen et al., 2013) and reaction probabilities of Davis et al. (2008) assuming ammonium sulfate.

\section{A6 CNRM-CM5-3}

The CNRM-CM5-3 CCM is based on the CNRM-CM5-3 AOGCM of CNRM/CERFACS, whose version 5.1 has been used in CMIP5 simulations and is described by Voldoire et al. (2012). The CCM includes some fundamental changes from the previous version (CNRM-ACM), which was extensively evaluated in the context of the CCMVal-2 validation activity. The most notable changes concern the radiation code of the GCM (Morcrette, 1990, 1991; Morcrette et al., 2001), the parameterization of non-orographic gravity waves, stochastic parameterization triggered by convection as described by Lott and Guez (2013), and the inclusion of the detailed stratospheric chemistry online within the GCM (Michou et al., 2011). To clarify, CCMI-1 simulations have been performed in an AMIP-type mode, the atmospheric GCM (v6.03) being forced by SSTs and sea ice, without the use of the SURFEX external surface scheme.

\section{A7 EMAC}

The Modular Earth Submodel System (MESSy; Jöckel et al., 2005, 2006, 2010) is a software package providing a framework for a standardized, bottom-up implementation of Earth System Models with flexible complexity. "Bottom-up" means, the MESSy software provides an infrastructure with generalized interfaces for the standardized control and interconnection (coupling) of ESM components (dynamic cores, physical parameterizations, chemistry packages, diagnostics, etc.), which are called submodels. MESSy comprises currently about 60 submodels (coded according to the MESSy standards) in different categories: infrastructure (i.e. framework) submodels, atmospheric chemistry related submodels, physics related submodels, and diagnostic submodels. The ECHAM/MESSy Atmospheric Chemistry (EMAC) model uses the MESSy to link multi-institutional computer codes to the core atmospheric model, i.e. the 5th generation European Centre Hamburg general circulation model (Roeckner et al., 2003, 2006). Updates used for CCMI-1 (EMAC version 2.51) are documented in detail by Jöckel et al. (2016).

\section{A8 GEOSCCM}

The Goddard Earth Observing System Chemistry-Climate Model (GEOSCCM) is based on the GEOS-5 GCM (Molod et al., 2012, 2015) coupled to the stratospheric and tropospheric (StratTrop) Global Modeling Initiative (GMI) chemical mechanism (Strahan et al., 2007; Duncan et al., 2007). This version uses a $\mathrm{C} 48$ cubed-sphere grid, which has been regridded to $2.5^{\circ}$ longitude $\times 2^{\circ}$ latitude horizontal resolution and 72 vertical layers up to $80 \mathrm{~km}$. The response of tropospheric ozone to variations in the El Niño-Southern Oscillation (ENSO) compared to observations were described by Oman et al. (2011, 2013). An earlier version of the model contributed to the ACCMIP activity (Lamarque et al., 2013).

\section{A9 GFDL-AM3 AND GFDL-CM3}

AM3 is the atmospheric component of the Geophysical Fluid Dynamic Laboratory (GFDL) global coupled atmosphereocean-land-sea ice model (CM3), which includes interactive stratosphere-troposphere chemistry and aerosols at $\mathrm{C} 48$ cubed-sphere horizontal resolution (approximately $2^{\circ} \times 2^{\circ}$ ) (Donner et al., 2011; Austin et al., 2013; Naik et al., 2013). In support of CCMI-1, we conduct a suite of multi-decadal hindcast simulations (1979-2014) designed to isolate the response of atmospheric constituents to historical changes in human-induced emissions, methane, wildfires, and meteorology. Details of these simulations are described by Lin et al. (2014, 2015a, b). We implement a height-dependent nudging technique, relaxing the model to NCEP $u$ and $v$ with a timescale of $6 \mathrm{~h}$ in the surface level, but weakening the nudging strength linearly with decreasing pressure (e.g. relaxing with a timescale of $60 \mathrm{~h}$ by $100 \mathrm{hPa}$ and $600 \mathrm{~h}$ by $10 \mathrm{hPa}$ ) (Lin et al., 2012a). To quantify stratospheric influence on tropospheric ozone, we define a stratospheric ozone tracer relative to a dynamically varying tropopause and subjecting it to chemical and depositional loss in the same manner as odd oxygen in the troposphere (Lin et al., 2012b, 2015a). These AM3 simulations have been evaluated against a broad suite of observations. Analysis of satellite measurements, daily ozonesondes, and multi-decadal in situ observation records indicates that the nudged GFDL-AM3 model captures many salient features of observed ozone over the North Pacific and North America, including the influences from Asian pollution events (Lin et al., 2012a), deep tropopause folds (Lin et al., 2012b), as well as their variability on interannual to decadal timescales (Lin et al., 2014, 2015a) and long-term trends (Lin et al., 2015b). The model also captures interannual variability of ozone in the lower stratosphere and its re- 
sponses to ENSO events and volcanic aerosols as measured by ozonesondes (Lin et al., 2015a).

\section{A10 HadGEM3-ES}

The Met Office model (HadGEM3-ES, formerly UMUKCAMETO) has changed significantly since CCMVal-2. The underlying atmosphere model is now HadGEM3 (Walters et al., 2014), with horizontal resolution increased from $3.75^{\circ}$ longitude $\times 2.5^{\circ}$ latitude to $1.875^{\circ}$ longitude $\times 1.25^{\circ}$ latitude, and the number of levels spanning the model domain $0-85 \mathrm{~km}$ increased from 60 to 85 . The move to the HadGEM3 model has significantly reduced two critical biases seen in UMUKCA-METO simulations in which stratospheric air was too old and the tropical tropopause too warm (Morgenstern et al., 2009). As a consequence of the improvements in tropical tropopause temperatures, water vapour concentrations entering the stratosphere are no longer prescribed and are now interactively determined by the model. For the scenario simulations coupled ocean (NEMO vn3.4; Madec, 2008) and sea ice (CICE vn4.1; Hunke and Lipscombe, 2008) modules are now included. Significant developments to the UKCA chemistry component (Morgenstern et al., 2009; O'Connor et al., 2014) include the replacement of the stratosphere-only scheme used in UMUKCAMETO with a combined stratosphere-troposphere chemistry scheme, with increased numbers of tracers, chemical species and reactions, the Mainz Isoprene Scheme (MIM, Pöschl et al., 2000), interactive lightning emissions (O'Connor et al., 2014), interactive photolysis rates (FAST-JX; Telford et al., 2013), the CLASSIC aerosol scheme (Bellouin et al., 2011), and a resistance-type approach to dry deposition (Wesely, 1989; O'Connor et al., 2014).

The model, in the HadGEM2 predecessor version, participated in ACCMIP. Relative to this configuration, changes include improved vertical resolution and range, a wholeatmosphere chemistry scheme with expanded NMVOC chemistry, and online photolysis, as detailed above.

\section{A11 LMDz-REPROBUS}

LMDz-REPROBUS is a coupled CCM, formed by the coupling of the LMD GCM and the REPROBUS atmospheric chemistry module. When linked to the NEMO ocean model, the configuration is identical to the IPSL atmosphereocean climate model but with atmospheric chemistry. The LMDZrepro model used for CCMVal-2 had 50 levels and a resolution of $2.5^{\circ}$ latitude $\times 3.75^{\circ}$ longitude with a top at about $65 \mathrm{~km}$. The CCMI-1 simulations already completed have been performed with the CMIP5 version (LMDzREPROBUS-CM5) that have 39 levels and a resolution of $2.5^{\circ}$ latitude $\times 3.75^{\circ}$ longitude with a top at about $70 \mathrm{~km}$ (Dufresne et al., 2013). We plan to rerun the same CCMI-1 simulations with the CM6 version that has 79 levels and a resolution of $1.25^{\circ}$ latitude $\times 2.5^{\circ}$ longitude with a top at about $80 \mathrm{~km}$.

\section{A12 MOCAGE}

MOCAGE (Modèle de Chimie Atmosphérique de Grande Echelle) is a Météo-France's CTM. MOCAGE combines the RACM (Stockwell et al., 1997) tropospheric and the REPROBUS (Lefèvre et al., 1994) stratospheric chemistry schemes, consistently applied from the surface to the model top. It simulates 109 gaseous species (there are no aerosols in these CCMI-1 runs) that are grouped in families, with 91 being transported. In the stratosphere, nine heterogeneous reactions are described, using the parameterization of Carslaw et al. (1995a). Moreover, 52 photolysis and 312 thermal reactions are considered. The photolysis rates follow look-up tables and are modified to account for cloudiness, following Chang et al. (1987). The model includes a reaction pathway for $\mathrm{HO}_{2}+\mathrm{NO}$ to yield $\mathrm{HNO}_{3}$ (Butkovskaya et al., 2007).

The resolution of the model is $2^{\circ} \times 2^{\circ}$ on a latitudelongitude grid, with 47 levels to $5 \mathrm{hPa}$. For the REF-C1SD and SEN-C1SD-fEmis experiments, we use ERA-Interim forcings. For the REF-C1 and REF-C 2 experiments, the meteorological forcing is taken from an update of the CNRMCM model, which was used for CMIP5 simulations (Voldoire et al., 2012). However, convective transport of species is recomputed following the parameterization by Bechtold et al. (2001). Convective in-cloud scavenging is determined in the updraft (Mari et al., 2000), whereas wet deposition due to stratiform precipitations follow Giorgi and Chameides (1986). A 1-year simulation has been performed to compute dry deposition velocities following the Wesely (1989) approach. Values have been averaged to get monthly diurnal profiles. The same values have been used for all simulations.

Except for lightning $\mathrm{NO}_{x}$, natural emissions are monthly mean distributions taken from Global Emissions InitiAtive (GEIA) inventories. Lightning $\mathrm{NO}_{x}$ is parameterized in the convection scheme following Price et al. (1997) and is hence climate-sensitive. Methane concentrations were prescribed at the surface following a monthly zonal climatology taking the evolution of the global value as a function of RCPs into account.

\section{A13 MRI-ESM1r1}

MRI-ESM1r1 is an updated version of the Earth System Model MRI-ESM1, which was used for future climate projection in the 5th Assessment Report of the Intergovernmental Panel on Climate Change (IPCC, 2013). The vertical resolution of MRI-ESM1r1 (L80) is improved compared to MRI-ESM1 (L48). The SCUP coupler (Yoshimura and Yukimoto, 2008) is used to couple the atmosphere, ocean, aerosol, and (gas-phase) chemistry modules, which make up MRIESM1r1. The chemistry module is MRI-CCM2 (Deushi and Shibata, 2011), which is an updated version of MRI-CCM1 
used for CCMVal-2. In MRI-CCM2, a tropospheric hydrocarbon oxidation scheme of medium complexity is newly added.

\section{A14 SOCOLv3}

Since CCMVal-2, the SOCOL model (SOlar Climate Ozone Links; Stenke et al., 2013) has significantly changed. SOCOLv2, which participated in CCMVal-2, was a combination of the GCM MA-ECHAM4 (Manzini et al., 1997) and the CTM MEZON (Rozanov et al., 1999; Egorova et al., 2003), while the third and current version, SOCOLv3, is based on MA-ECHAM5 (Roeckner et al., 2006; Manzini et al., 2006). The advection of chemical trace species is now calculated by the flux-form semi-Lagrangian scheme of Lin and Rood (1996) instead of the previously applied hybrid advection scheme. This change made the mass correction applied to certain tracers in SOCOLv2 obsolete. Furthermore, the unsatisfying separation of tropospheric and stratospheric water vapour fields in SOCOLv2 has also become obsolete. SOCOLv3 considers only one water vapour field, i.e. the ECHAM5 water vapour. Advection, convection, and the tropospheric hydrological cycle are calculated by the GCM, while chemical water vapour production/destruction as well as PSC formation are calculated by the chemistry module.

For CCMI-1 SOCOL was run with T42 horizontal resolution, which corresponds approximately to $2.8^{\circ} \times 2.8^{\circ}$, and with 39 vertical levels between the Earth' surface and $0.01 \mathrm{hPa}(\sim 80 \mathrm{~km})$. Further important modifications for the CCMI-1 set-up include an isoprene oxidation mechanism (Pöschl et al., 2000), the online calculation of lightning $\mathrm{NO}_{x}$ emissions (Price and Rind, 1992), treatment of the effects produced by different energetic particles (Rozanov et al., 2012), updated reaction rates and absorption cross sections (Sander et al., 2011b), improved solar heating rates (Sukhodolov et al., 2014), as well as a parameterization of cloud effects on photolysis rates (Chang et al., 1987). Furthermore, the ODS species are no longer transported as families, but as separate tracers.

\section{A15 TOMCAT}

TOMCAT is a global 3-D offline chemical transport model (Chipperfield, 2006). The model is usually forced by ECMWF meteorological (re)analyses, although GCM output can also be used. When using ECMWF fields, as in the CCMI-1 experiments, the model reads in the 6-hourly fields of temperature, humidity, vorticity, divergence, and surface pressure. The resolved vertical motion is calculated online from the vorticity. The model has parameterizations for sub-grid-scale tracer transport by convection (Stockwell and Chipperfield, 1999; Feng et al., 2011) and boundary layer mixing (Holtslag and Boville, 1993). Tracer advection is performed using the conservation of second order moments scheme by Prather (1986). The CTM can be used with a variety of chemistry and aerosol schemes including stratospheric chemistry (Chipperfield et al., 2015), tropospheric chemistry (e.g. Monks et al., 2012) and idealized tracers. For the CCMI-1 experiments, the model was run at horizontal resolution of $2.8^{\circ} \times 2.8^{\circ}$ with 60 levels from the surface to $\sim 60 \mathrm{~km}$. Experiments with stratospheric chemistry and idealized tracers were performed.

\section{A16 ULAQ-CCM}

The ULAQ-CCM is a climate-chemistry coupled model with an interactive aerosol module (a compact description was given by Morgenstern et al., 2010, for CCMVal-2). Since then, the following updates have been made to the model (Pitari et al., 2014): (a) increase in horizontal and vertical resolution; (b) inclusion of a numerical code for the formation of upper tropospheric cirrus cloud ice particles (Kärcher and Lohmann, 2002; Pitari et al., 2015a); (c) upgrade of the radiative transfer code for calculations of photolysis, heating rates, and radiative forcing. This is a two-stream $\delta$-Eddington approximation operating online in the ULAQCCM, used for photolysis rate calculation at UV-visible (Vis) wavelengths, solar heating rates, and radiative forcing at UV-Vis-NIR (near-infrared) bands (Randles et al., 2013; Pitari et al., 2015b). In addition, a companion broadband, $k$ distribution longwave radiation module is used to compute radiative transfer and heating rates in the planetary infrared spectrum (Chou et al., 2001; Pitari et al., 2015c). Calculations of photolysis rates and radiative fluxes have been evaluated in the framework of CCMVal (SPARC, 2010) and AeroCom inter-comparison campaigns (Randles et al., 2013). The chemistry-aerosol module is organized with all medium and short-lived species grouped in families. It includes the major components of tropospheric aerosols (sulfate, carbonaceous aerosol, soil dust, sea salt), with calculation at each size bin of surface fluxes, removal and transport terms, in external mixing conditions. A modal approximation is used for nitrate aerosols. Wet and dry deposition is treated following Müller and Brasseur (1995), using a climatological cloud distribution. Lower-stratospheric denitrification and dehydration are calculated using the predicted size distribution of PSC particles.

\section{A17 UMSLIMCAT}

The UMSLIMCAT has only undergone minor changes since CCMVal-2. The model is based on a old version of the MetUM and, although it performs well in terms of stratospheric chemistry and dynamics, the model is not actively developed. Core UMSLIMCAT simulations are performed in order to increase the range of simulations available and to provide some continuity with previous CCM studies. Compared to CCMVal-2, the minor model updates are (i) updated photolysis scheme with an improved treatment of ozone profiles in the online look-up table, (ii) the use of the CCMI-1 
aerosol surface area density (SAD), and (iii) an updated solar flux representation. Dhomse et al. $(2011,2013,2015)$ describe the implementation of this representation and present an analysis of solar flux variability and volcanic aerosol in the model.

\section{A18 UMUKCA-UCAM}

UMUKCA-UCAM is an atmosphere-only CCM, based on the HadGEM3 model (revision 2). The chemistry in UMUKCA-UCAM is based on a similar scheme as was used in the UMUKCA models in CCMVal-2 (focusing on the chemistry of stratosphere; Bednarz et al., 2016), but with an explicit treatment of halogen source gases, i.e. no lumping. Since CCMVal-2, significant improvements to the model physics have been made, and although the model resolution is degraded to run at N48L60 $\left(3.75^{\circ} \times 2.5^{\circ}\right)$ in the atmosphere, the model physics is identical to HadGEM3. Relative to the UMUKCA models used for CCMVal-2, the FAST-JX online photolysis scheme (Telford et al., 2013) is now included, as are interactive lightning emissions, the CLASSIC aerosol scheme (Bellouin et al., 2011), and a resistance-type approach to dry deposition (Wesely, 1989).

\section{Appendix B: Deviations from CCMI-1 recommendations}

We list here the ways in which simulations and model setups deviate from Eyring et al. (2013a). Furthermore, simulations submitted to the archive that are additional to those solicited by Eyring et al. (2013a) and Hegglin et al. (2016) are described here. Errors with CCMI-1 models or simulations that come to light after publication of this paper will be documented at https://blogs.reading.ac.uk/ccmi/ badc-data-access/data-errata-and-notes/.

\section{B1 ACCESS CCM and NIWA-UKCA}

For some simulations, anthropogenic NMVOC emissions were held at their 1960 levels for 1960-2000 in about half of the NIWA-UKCA simulations. This error was picked up and corrected for the later simulations but remains in earlier simulations. Simulations affected by this problem include: REF-C1 (r2, r3), REF-C2 (r1, r2, r3, r4), SEN-C2-fODS (r1), and SEN-C2-fGHG (r1). Not affected are REF-C1 (r1), SENC1-fEMIS (r1), REF-C2 (r5), SEN-C2-fODS (r2), SEN-C2fGHG (r2, r3), SEN-C2-fCH4 (r1), and SEN-C2-fN2O (r1).

As noted before, ACCESS CCM and NIWA-UKCA do not consider the radiative impacts of stratospheric aerosol. Also there is no variance correction applied to sea surface temperatures in the simulations without interactive ocean.

\section{B2 CCSRNIES MIROC3.2}

HadISST1 data were used for REF-C1 and REF-C1SD simulations. Chemical reactions important in the troposphere are not included, but the stratospheric chemistry scheme is just used in the troposphere. Solar radiation at wavelengths shorter than $177.5 \mathrm{~nm}$ is not considered except for Lyman- $\alpha$. Atmospheric ionization by solar protons is not included.

\section{B3 CMAM}

The ACCMIP historical database of emissions (Lamarque et al., 2010) was used for the REF-C1 and REF-C1SD simulations up to the year 2000, with the RCP8.5 emissions used for the following years. It was also used up to 2000 for the REF-C2 and associated scenario simulations. Emissions at intermediate years were linearly interpolated from the years given in the database. An additional emission of $\mathrm{CO}$ of $250 \mathrm{Tg}(\mathrm{CO})$ year $^{-1}$ was included to account for $\mathrm{CO}$ from isoprene oxidation, with the emissions distributed following the monthly emissions of isoprene from Guenther et al. (1995). No variance correction was applied to the specified SSTs.

\section{B4 EMAC}

Due to a unit conversion error at data import, the extinction of stratospheric aerosols was too low, by a factor of approximately 500. The effect of stratospheric background aerosol on radiative heating rates has been tested by sensitivity simulations and estimated to be smaller than the interannual standard deviation. However, the dynamical effects of large volcanic eruptions (Mt. Pinatubo in 1991, El Chichón in 1982, etc.) are essentially not represented in the simulations, except for the contribution to the tropospheric temperature signal induced by the prescribed SSTs. The chemical effects (through heterogeneous chemistry), however, are included, since the prescribed aerosol surface areas were treated correctly.

Next, due to an error in the model set-up, the timing of the road traffic emissions was unfortunately wrong; instead of updating the monthly input fields every month, they have been updated only every year, and thus in 1950 emissions of January 1950 have been used, in 1951 the emissions of February 1950, etc.

And last, but not least, some of the diagnostic tracers have been treated differently, as detailed by Jöckel et al. (2016).

More details on the deviations from the CCMI-1 recommendations are documented by Jöckel et al. (2016, see their Sect. 3.12 and Table A1).

\section{B5 GFDL-AM3}

The AM3_BASE simulation (i.e. REF-C1SD) applies interannually varying emissions of aerosol and ozone precursors from human activity, based on Lamarque et al. (2010) for 1980-2000 and RCP 8.5 projections (Riahi et al., 2011) 
Table B1. Summary of forcings and emissions data used in the GFDL-AM3 hindcast simulations, with italics indicating where the data differ from the CCMI-1 recommendations. L2014 = Lin et al. (2014).

\begin{tabular}{|c|c|c|c|c|c|c|c|}
\hline Experiment & $\begin{array}{l}\text { L2014 } \\
\text { name }\end{array}$ & Meterology & Period & RF & $\mathrm{CH}_{4}$ & Anth. emissions & Fire emissions \\
\hline REF-C1SD & BASE & $\operatorname{NCEP} u \& v$ & $1980-2010$ & REF-C1 & REF-C1 & $\begin{array}{l}\text { REF-C1 (Except } \mathrm{SO}_{2}, \\
\mathrm{BC} \text {, and OC after 1996) }\end{array}$ & $\begin{array}{l}\text { REF C1 (RETRO before } \\
\text { 1996, GFEDv3 for } \\
\text { 1997-2010) }\end{array}$ \\
\hline SEN-C1SD-fEmis & FIXEMIS & as REF-C1SD & $1980-2010$ & REF-C1 & $2000 *$ & 1970-2010 climatology* & 1970-2010 climatology* \\
\hline SEN-C1SD-Emis & IAVFIRE & as REF-C1SD & $1980-2010$ & CCMI-1 & $2000 *$ & 1970-2010 climatology* & $\mathrm{REF}-\mathrm{C} 1$ \\
\hline SEN-C1-Emis & AMIP & N/A & $1960-2010$ & $\mathrm{REF}-\mathrm{C} 1$ & $2000 *$ & $\begin{array}{l}\mathrm{O}_{3} \text { precursors: FIXEMIS; } \\
\text { aerosol precursors: } \mathrm{REF}-\mathrm{Cl}\end{array}$ & 1970-2010 climatology \\
\hline
\end{tabular}

beyond 2005, linearly interpolated for intermediate years. The AM3_FIXEMIS simulation (i.e. SEN-C1SD-fEmis), with anthropogenic and biomass burning emissions set to the 1970-2010 climatology and methane held constant at 2000 levels, is designed to isolate the role of meteorology. The IAVFIRE simulation (i.e. SEN-C1SD-Emis) applies interannual-varying monthly mean emissions from biomass burning based on Schultz et al. (2008) for 1970-1996 and GFEDv3 (Van der Werf et al., 2010) for 1997-2010. Otherwise, all forcings are the same as in FIXEMIS. The BASE, FIXEMIS, and IAVFIRE simulations with modified emissions are nudged to NCEP reanalysis winds over 1980 to 2010. We also conduct four ensemble simulations without nudging, driven by prescribed sea surface temperatures (SSTs) and atmospheric radiative forcing agents over 1960 to 2010 (SEN-C1-Emis; Table B1). In SEN-C1SD-fEmis, emissions of ozone and aerosol precursors are fixed to the 1970-2010 climatology, instead of the 1980 levels recommended by CCMI-1. Due to an error in data processing, anthropogenic emissions of aerosol precursors $\left(\mathrm{SO}_{2}, \mathrm{BC}\right.$, and OC) after 1996 in the REF-C1SD simulation do not follow the CCMI-1 recommendation. Otherwise denoted in Table B1, all forcings follow the CCMI-1 recommendations.

\section{B6 HadGEM3-ES}

The specified-dynamics simulation (REF-C1SD) uses an anomaly correction to the ERA-I forcing data, as outlined in Mclandress et al. (2014). Two REF-C2 simulations only start in 2000. The three SEN-C2-fGHG simulations are forced with fixed year-2000 GHG-mixing ratios not 1960 ones, and also only start in 2000 .

\section{B7 MRI-ESM1r1}

The molecular weight of sulfate aerosols $\left(\mathrm{SO}_{4}\right)$ due to volcanic eruptions was inappropriately set to that of sulfur atom (S) in our REF-C1 and REF-C1SD simulations. As a result, the amount of volcanic aerosol in these simulations was one-third of its correct amount. Molecular weights of other aerosols (anthropogenic, biogenic, dust, etc.) are appropriately treated.

\section{B8 SOCOLv3}

Sea surface temperatures for REF-C2 and all sensitivity simulations based on REF-C2 were taken from the CESM1CAM5 model.

\section{B9 ULAQ CCM}

All CCMI-1 experiments have been conducted following the CCMI-1 recommendations. For the sensitivity cases SENC2-fGHG, SEN-C2-fODS, and SEN-C2-fODS2000, the following procedure has been used for $\mathrm{CH}_{4}, \mathrm{~N}_{2} \mathrm{O}$, and CFCs, which are both GHGs and ODSs. These species were fixed in the radiation-dynamics-climate modules in the fGHG experiment, leaving them to evolve in time for chemistry. The opposite choice was made for the two fODS experiments (1960, 2000), i.e. fixing these species in chemistry and letting them evolve in the radiation-dynamics-climate modules.

\section{B10 UMUKCA-UCAM}

The stratospheric aerosol climatology used is SPARC (2006), and is included in the chemistry, photolysis, and radiation schemes. Surface emissions (of $\mathrm{NO}_{x}, \mathrm{CO}$, and $\mathrm{HCHO}$ ) and the $\mathrm{NO}_{x}$ aircraft emissions are the same as used in the CCMVal2 REF-B2 simulation. 


\section{The Supplement related to this article is available online at doi:10.5194/gmd-10-639-2017-supplement.}

Author contributions. Olaf Morgenstern and Michaela I. Hegglin have devised the concept and written most of the paper. The other authors have contributed information pertaining to their individual models and have revised and helped formulate the paper.

Competing interests. The authors declare that they have no conflict of interest.

Acknowledgements. We thank the Centre for Environmental Data Analysis (CEDA) for hosting the CCMI data archive. This work has been supported by NIWA as part of its government-funded, core research. Olaf Morgenstern acknowledges support from the Royal Society Marsden Fund, grant 12-NIW-006, and under the Deep South National Science Challenge.. The authors wish to acknowledge the contribution of NeSI high-performance computing facilities to the results of this research. New Zealand's national facilities are provided by the New Zealand eScience Infrastructure (NeSI) and funded jointly by NeSI's collaborator institutions and through the Ministry of Business, Innovation \& Employment's Research Infrastructure programme (https://www.nesi.org.nz). The SOCOL team acknowledges support from the Swiss National Science Foundation under grant agreement CRSII2_147659 (FUPSOL II). CCSRNIES's research was supported by the Environment Research and Technology Development Fund (2-1303) of the Ministry of the Environment, Japan, and computations were performed on NEC-SX9/A(ECO) computers at the CGER, NIES. Wuhu Feng (NCAS) provided support for the TOMCAT simulations. Neal Butchart, Steven C. Hardiman, and Fiona M. O'Connor and the development of HadGEM3-ES were supported by the Joint UK DECC/Defra Met Office Hadley Centre Climate Programme (GA01101). Neal Butchart and Steven C. Hardiman also acknowledge additional support from the European Project 603557-STRATOCLIM under the FP7-ENV.2013.6.1-2 programme. Fiona M. O'Connor acknowledges additional support from the Horizon 2020 European Union's Framework Programme for Research and Innovation CRESCENDO project under grant agreement no. 641816. Slimane Bekki acknowledges support from the European Project 603557-STRATOCLIM under the FP7-ENV.2013.6.1-2 programme and from the Centre National d'Etudes Spatiales (CNES, France) within the SOLSPEC project. Kane Stone and Robyn Schofield acknowledge funding from the Australian Government's Australian Antarctic science grant program (FoRCES 4012), the Australian Research Council's Centre of Excellence for Climate System Science (CE110001028), the Commonwealth Department of the Environment (grant 2011/16853), and computational support from National computational infrastructure INCMAS project $\mathrm{q} 90$. The CNRM-CM chemistry-climate people acknowledge the support from Météo-France, CNRS, and CERFACS, and in particular the work of the entire team in charge of the CNRM/CERFACS climate model.

Edited by: A. Kerkweg

Reviewed by: two anonymous referees

\section{References}

Allan, W., Struthers, H., and Lowe, D. C.: Methane carbon isotope effects caused by atomic chlorine in the marine boundary layer: Global model results compared with Southern Hemisphere measurements, J. Geophys. Res., 112, D04306, doi:10.1029/2006JD007369, 2007.

Akiyoshi, H.: Development of a global 1-D chemically radiatively coupled model and an introduction to the development of a chemically coupled General Circulation Model, CGER's Supercomputer Monograph Report, Center for Global Environmental Reserch, National Institute for Environmental Studies, 4, 69 pp., 1997.

Akiyoshi, H.: Modeling of chemistry and chemistry-radiation coupling processes for the middle atmosphere and a numerical experiment on $\mathrm{CO}_{2}$ doubling with a 1-D coupled model, J. Meteorol. Soc. Jpn., 78, 563-584, 2000.

Akiyoshi, H., Zhou, L. B., Yamashita, Y., Sakamoto, K., Yoshiki, M., Nagashima, T., Takahashi, M., Kurokawa, J., Takigawa, M., and Imamura, T.: A CCM simulation of the breakup of the Antarctic polar vortex in the years 1980-2004 under the CCMVal scenarios, J. Geophys. Res., 114, D03103, doi:10.1029/2007JD009261, 2009.

Akiyoshi, H., Nakamura, T., Miyasaka, T., Shiotani, M., and Suzuki, M.: A nudged chemistry-climate model simulation of chemical constituent distribution at northern high?latitude stratosphere observed by SMILES and MLS during the 2009/2010 stratospheric sudden warming, J. Geophys. Res., 121, 13611380, doi:10.1002/2015JD023334, 2016.

Ammann, C. M., Joos, F., Schimel, D. S., Otto-Bliesner, B. L., and Tomas, R. A.: Solar influence on climate during the past millennium: results from transient simulations with the NCAR Climate System Model, P. Natl. Acad. Sci. USA, 104, 3713-3718, 2007.

Aquila, V., Oman, L. D., Stolarski, R. S., Colarco, P. R., and Newman, P. A.: Dispersion of the volcanic sulfate cloud from a Mount Pinatubo-like eruption, J. Geophys. Res., 117, D06216, doi:10.1029/2011JD016968, 2012.

Arakawa, A. and Schubert, W. H.: Interactions of cumulus cloud ensemble with the large-scale environment - Part I, J. Atmos. Sci., 31, 671-701, 1974.

Arfeuille, F., Luo, B. P., Heckendorn, P., Weisenstein, D., Sheng, J. X., Rozanov, E., Schraner, M., Brönnimann, S., Thomason, L. W., and Peter, T.: Modeling the stratospheric warming following the Mt. Pinatubo eruption: uncertainties in aerosol extinctions, Atmos. Chem. Phys., 13, 11221-11234, doi:10.5194/acp13-11221-2013, 2013

Atkinson, R., Baulch, D. L., Cox, R. A., Crowley, J. N., Hampson, R. F., Hynes, R. G., Jenkin, M. E., Rossi, M. J., and Troe, J.: Evaluated kinetic and photochemical data for atmospheric chemistry: Volume $\mathrm{I}-$ gas phase reactions of $\mathrm{O}_{x}, \mathrm{HO}_{x}, \mathrm{NO}_{x}$ and $\mathrm{SO}_{x}$ species, Atmos. Chem. Phys., 4, 1461-1738, doi:10.5194/acp-41461-2004, 2004.

Atkinson, R., Baulch, D. L., Cox, R. A., Crowley, J. N., Hampson, R. F., Hynes, R. G., Jenkin, M. E., Rossi, M. J., Troe, J., and IUPAC Subcommittee: Evaluated kinetic and photochemical data for atmospheric chemistry: Volume II - gas phase reactions of organic species, Atmos. Chem. Phys., 6, 3625-4055, doi:10.5194/acp-6-3625-2006, 2006.

Austin, J., Horowitz, L. W., Schwarzkopf, M. D., Wilson, R. J., and Levy, H.: Stratospheric ozone and temperature simulated from 
the preindustrial era to the present day, J. Climate, 26, 11, 35283543, doi:10.1175/jcli-d-12-00162.1, 2013.

Bacmeister, J. T., Suarez, M. J., and Robertson, F. R.: Rain reevaporation, boundary layer convection interactions, and Pacific rainfall patterns in an AGCM, J. Atmos. Sci., 63, 3383-3403, 2006.

Baumgaertner, A. J. G., Jöckel, P., and Brühl, C.: Energetic particle precipitation in ECHAM5/MESSy1 - Part 1: Downward transport of upper atmospheric $\mathrm{NO}_{x}$ produced by low energy electrons, Atmos. Chem. Phys., 9, 2729-2740, doi:10.5194/acp-92729-2009, 2009.

Bechtold, P., Bazile, E., Guichard, F., Mascart, P., and Richard, E.: A mass-flux convection scheme for regional and global models, Q. J. Roy. Meteorol. Soc., 127, 869-886, doi:10.1002/qj.49712757309, 2001.

Bednarz, E. M., Maycock, A. C., Abraham, N. L., Braesicke, P., Dessens, O., and Pyle, J. A.: Future Arctic ozone recovery: the importance of chemistry and dynamics, Atmos. Chem. Phys., 16, 12159-12176, doi:10.5194/acp-16-12159-2016, 2016.

Bellouin, N., Rae, J., Jones, A., Johnson, C., Haywood, J., and Boucher, O.: Aerosol forcing in the Climate Model Intercomparison Project (CMIP5) simulations by HadGEM2-ES and the role of ammonium nitrate, J. Geophys. Res., 116, D20206, doi:10.1029/2011JD016074, 2011.

Best, M. J., Pryor, M., Clark, D. B., Rooney, G. G., Essery, R. L. H., Ménard, C. B., Edwards, J. M., Hendry, M. A., Porson, A., Gedney, N., Mercado, L. M., Sitch, S., Blyth, E., Boucher, O., Cox, P. M., Grimmond, C. S. B., and Harding, R. J.: The Joint UK Land Environment Simulator (JULES), model description Part 1: Energy and water fluxes, Geosci. Model Dev., 4, 677-699, doi:10.5194/gmd-4-677-2011, 2011.

Bian, H. and Prather, M. J.: Fast-J2: Accurate simulation of stratospheric photolysis in global chemical models, J. Atmos. Chem., 41, 281-296, 2002.

Bougeault, P.: A simple parameterization of the large-scale effects of cumulus convection, Mon. Weather Rev., 113, 2108-2121, 1985.

Butchart, N., Cionni, I., Eyring, V., Waugh, D. W., Akiyoshi, H., Austin, J., Brühl, C., Chipperfield, M. P., Cordero, E., Dameris, M., Deckert, R., Frith, S., M., Garcia, R. R., Gettelman, A., Giorgetta, M. A., Kinnison, D. E., Li, F., Mancini, E., Manzini, E., McLandress, C., Pawson, S., Pitari, G., Rozanov, E., Sassi, F., Shepherd, T. G., Shibata, K., and Tian, W.: Chemistryclimate model simulations of 21 st century stratospheric climate and circulations changes, J. Climate, 23, 5349-5374, doi:10.1175/2010JCLI3404.1, 2010.

Butkovskaya, N., Kukui, A.. and Le Bras. G.: $\mathrm{HNO}_{3}$ forming channel of the $\mathrm{HO}_{2}+\mathrm{NO}$ reaction as a function of pressure and temperature in the ranges of 72-600 Torr and 223-323 K, J. Phys. Chem. A, 111, 9047-9053, doi:10.1021/jp074117m, 2007.

Cagnazzo, C., Manzini, E., Giorgetta, M. A., Forster, P. M. D. F., and Morcrette, J. J.: Impact of an improved shortwave radiation scheme in the MAECHAM5 General Circulation Model, Atmos. Chem. Phys., 7, 2503-2515, doi:10.5194/acp-7-2503-2007, 2007.

Carslaw, K. S., Luo, B. P., and Peter, T.: An analytic-expression for the composition of aqueous $\mathrm{HNO}_{3}-\mathrm{H}_{2} \mathrm{SO}_{4}$ stratospheric aerosols including gas-phase removal of $\mathrm{HNO}_{3}$, Geophys. Res. Lett., 22, 1877-1880, 1995.
Carslaw, K. S., Luo, B. P., Peter, T., and Clegg, S. L.: Vapour pressures of $\mathrm{H}_{2} \mathrm{SO}_{4} / \mathrm{HNO}_{3} / \mathrm{HBr} / \mathrm{H}_{2} \mathrm{O}$ solutions to low stratospheric temperatures, Geophys. Res. Lett., 22, 247-250, 1995.

Chang, J. S., Brost, R. A., Isaksen, I. S. A., Madronich, S., Middleton, P., Stockwell, W. R., and Walcek, C.: A three-dimensional Eulerian acid deposition model: Physical concepts and formulation, J. Geophys. Res., 92, 14681-14700, 1987.

Chin, M., Ginoux, P., Kinne, S., Torres, O., Holben, B. N., Duncan, B. N., Martin, R. V., Logan, J. A., Higurashi, A., and Nakajima, T.: Tropospheric aerosol optical thickness from the GOCART model and comparisons with satellite and sun photometer measurements, J. Atmos. Sci., 59, 461-483, 2002.

Chipperfield, M. P.: Multiannual simulations with a threedimensional chemical transport model, J. Geophys. Res., 104, 1781-1805, 1999.

Chipperfield, M. P.: New version of the TOMCAT/SLIMCAT offline chemical transport model: Intercomparison of stratospheric tracer experiments, Q. J. Roy. Meteorol. Soc., 132, 1179-1203, 2006.

Chipperfield, M. P., Dhomse, S. S., Feng, W., McKenzie, R. L., Velders, G., and Pyle, J. A.: Quantifying the ozone and UV benefits already achieved by the Montreal Protocol, Nature Comm., 6, 7233, doi:10.1038/ncomms8233, 2015.

Chou, M.-D. and Suarez, M. J: A solar radiation parameterization for atmospheric studies, NASA Technical Report Series on Global Monitoring and Data Assimilation, 104606, v15, 40 pp., 1999.

Chou, M.-D., Suarez, M. J., Ho, C.-H., Yan, M. M.-H., and Lee, K.-T.: Parameterizations for cloud overlapping and short-wave single-scattering properties for use in general circulation and cloud ensemble members, J. Climate, 11, 202-214, 1997.

Chou, M.-D., Suarez, M. J., Liang, X. Z., and Yan, M. M.-H.: A thermal infrared radiations parameterization for atmospheric studies, NASA Technical Report Series on Global Monitoring and Data Assimilation, 104606, v19, 56 pp., 2001.

Clegg, S. M. and Abbatt, J. P. D.: Oxidation of $\mathrm{SO}_{2}$ by $\mathrm{H}_{2} \mathrm{O}_{2}$ on ice surfaces at $228 \mathrm{~K}$ : a sink for $\mathrm{SO}_{2}$ in ice clouds, Atmos. Chem. Phys., 1, 73-78, doi:10.5194/acp-1-73-2001, 2001.

Colarco, P., Da Silva, A., Chin, M., and Diehl, T.: Online simulations of global aerosol distributions in the NASA GEOS-4 model and comparisons to satellite and ground-based aerosol optical depth, J. Geophys. Res.-Atmos., 115, D14207, doi:10.1029/2009JD012820, 2010.

Collins, W. J., Bellouin, N., Doutriaux-Boucher, M., Gedney, N., Halloran, P., Hinton, T., Hughes, J., Jones, C. D., Joshi, M., Liddicoat, S., Martin, G., O’Connor, F., Rae, J., Senior, C., Sitch, S., Totterdell, I., Wiltshire, A., and Woodward, S.: Development and evaluation of an Earth-System model - HadGEM2, Geosci. Model Dev., 4, 1051-1075, doi:10.5194/gmd-4-10512011, 2011.

Collins, W. J., Lamarque, J.-F., Schulz, M., Boucher, O., Eyring, V., Hegglin, M. I., Maycock, A., Myhre, G., Prather, M., Shindell, D., and Smith, S. J.: AerChemMIP: Quantifying the effects of chemistry and aerosols in CMIP6, Geosci. Model Dev. Discuss., doi:10.5194/gmd-2016-139, in review, 2016.

Considine, D. B., Douglass, A. R., Connell, P. S., Kinnison, D. E., and Rotman, D. A.: A polar stratospheric cloud parameterization for the global modeling initiative three-dimensional model 
and its response to stratospheric aircraft, J. Geophys. Res., 105, 3955-3973, doi:10.1029/1999JD900932, 2000.

Davis, J. M., Bhave, P. V., and Foley, K. M.: Parameterization of $\mathrm{N}_{2} \mathrm{O}_{5}$ reaction probabilities on the surface of particles containing ammonium, sulfate, and nitrate, Atmos. Chem. Phys., 8, 52955311, doi:10.5194/acp-8-5295-2008, 2008.

Dee, D. P., Uppala, S. M., Simmons, A. J., Berrisford, P., Poli, P., Kobayashi, S., Andrae, U., Balmaseda, M. A., Balsamo, G., Bauer, P., Bechtold, P., Beljaars, A. C. M., van de Berg, I., Biblot, J., Bormann, N., Delsol, C., Dragani, R., Fuentes, M., Greer, A. J., Haimberger, L., Healy, S. B., Hersbach, H., Holm, E. V., Isaksen, L., Kallberg, P., Kohler, M., Matricardi, M., McNally, A. P., Mong-Sanz, B. M., Morcette, J.-J., Park, B.-K., Peubey, C., de Rosnay, P., Tavolato, C., Thepaut, J. N., and Vitart, F.: The ERAInterim reanalysis: Configuration and performance of the data assimilation system, Q. J. Roy. Meteorol. Soc., 137, 553-597, 2011.

Déqué, M.: Frequency of precipitation and temperature extremes over France in an anthropogenic scenario: model results and statistical correction according to observed values, Glob. Planet. Change, 57, 16-26, 2007.

Deushi, M. and Shibata, K.: Development of a Meteorological Research Institute chemistry-climate model version 2 for the study of tropospheric and stratospheric chemistry, Pap. Meteorol. Geophys., 62, 1-46, 2011.

Dhomse, S., Chipperfield, M. P., Feng, W., and Haigh, J. D.: Solar response in tropical stratospheric ozone: a 3-D chemical transport model study using ERA reanalyses, Atmos. Chem. Phys., 11, 12773-12786, doi:10.5194/acp-11-12773-2011, 2011.

Dhomse, S. S., Chipperfield, M. P., Feng, W., Ball, W. T., Unruh, Y. C., Haigh, J. D., Krivova, N. A., Solanki, S. K., and Smith, A. K.: Stratospheric O3 changes during 2001-2010: the small role of solar flux variations in a chemical transport model, Atmos. Chem. Phys., 13, 10113-10123, doi:10.5194/acp-1310113-2013, 2013.

Dhomse, S. S., Chipperfield, M., Feng, W., Hossaini, R., Mann, G. W., and Santee, M.: Revisiting the hemispheric asymmetry in midlatitude ozone changes following the Mount Pinatubo eruption: A 3-D model study, Geophys. Res. Lett., 42, 1-10, doi:10.1002/2015GL063052, 2015.

Dietmüller, S., Jöckel, P., Tost, H., Kunze, M., Gellhorn, C., Brinkop, S., Frömming, C., Ponater, M., Steil, B., Lauer, A., and Hendricks, J.: A new radiation infrastructure for the Modular Earth Submodel System (MESSy, based on version 2.51), Geosci. Model Dev., 9, 2209-2222, doi:10.5194/gmd-9-22092016, 2016.

Donner, L. J., Wyman, B. L., Hemler, R. S., Horowitz, L. W., Ming, Y., Zhao, M., Golaz, J.-C., Ginoux, P., Lin, S.-J., Schwarzkopf, M. D., Austin, J., Alaka, G., Cooke, W. F., Delworth, T. L., Freidenreich, S. M., Gordon, C. T., Griffies, S. M., Held, I. M., Hurlin, W. J., Klein, S. A., Knutson, T. R., Langenhorst, A. R., Lee, H.-C., Lin, Y., Magi, B. I., Malyshev, S. L., Milly, P. C. D., Naik, V., Natha, M. J., Pincus, R., Ploshay, J. J., Ramaswamy, V., Seman, C. J., Shevliakova, E., Sirutis, J. J., Stern, W. F., Stouffer, R. J., Wilson, R. J., Winton, M., Wittenberg, A. T., and Zeng, F.: The dynamical core, physical parameterizations, and basic simulation characteristics of the atmospheric component AM3 of the GFDL Global Coupled Model CM3, J. Climate, 24, 3484-3519, 2011.
Douville H., Planton, S., Royer, J. F., Stephenson, D. B., Tyteca, S., Kergoat, L., Lafont, S., and Betts, R. A.: Importance of vegetation feedbacks in doubled- $\mathrm{CO}_{2}$ climate experiments, J. Geophys. Res.-Atmos., 105, 14841-14861, 2000.

Douville, H.: Stratospheric polar vortex influence on Northern Hemisphere winter climate variability, Geophys. Res. Lett., 36, L18703, doi:10.1029/2009GL039334, 2009.

Dufresne, J.-L., Foujols, M. A., Denvil, S., Caubel, A., Marti, O., Aumont, O., Balkanski, Y., Bekki, S., Bellenger, H., Benshila, R., Bony, S., Bopp, L., Braconnot, P., Brockmann, P., Cadule, P., Cheruy, F., Codron, F., Cozic, A., Cugnet, D., de Noblet, N., Duvel, J.-P., Ethé, C., Fairhead, L., Fichefet, T., Flavoni, S., Friedlingstein, P., Grandpeix, J.-Y., Guez, L., Guilyardi, E., Hauglustaine, D., Hourdin, F., Idelkadi, A., Ghattas, J., Joussaume, S., Kageyama, M., Krinner, G., Labetoulle, S., Lahellec, A., Lefebvre, M.-P., Lefevre, F., Levy, C., Li, Z. X., Lloyd, J., Lott, F., Madec, G., Mancip, M., Marchand, M., Masson, S., Meurdesoif, Y., Mignot, J., Musat, I., Parouty, S., Polcher, J., Rio, C., Schulz, M., Swingedouw, D., Szopa, S., Talandier, C., Terray, P., Viovy, N., and Vuichard, N.: Climate change projections using the IPSL-CM5 Earth System Model: from CMIP3 to CMIP5, Clim. Dynam., 40, 2123-2165, 2013.

Duncan, B. N., Strahan, S. E., Yoshida, Y., Steenrod, S. D., and Livesey, N.: Model study of the cross-tropopause transport of biomass burning pollution, Atmos. Chem. Phys., 7, 3713-3736, doi:10.5194/acp-7-3713-2007, 2007.

Edwards, J. M. and Slingo, A.: Studies with a flexible new radiation code. I: Choosing a configuration for a large-scale model, Q. J. Roy. Meteorol. Soc., 122, 689-719, 1996.

Egorova, T. A., Rozanov, E. V., Zubov, V. A., and Karol, I. L.: Model for investigating ozone trends (MEZON), Izv. Atmos. Ocean. Phys., 39, 277-292, 2003.

Ermolli, I., Matthes, K., Dudok de Wit, T., Krivova, N. A., Tourpali, K., Weber, M., Unruh, Y. C., Gray, L., Langematz, U., Pilewskie, P., Rozanov, E., Schmutz, W., Shapiro, A., Solanki, S. K., and Woods, T. N.: Recent variability of the solar spectral irradiance and its impact on climate modelling, Atmos. Chem. Phys., 13, 3945-3977, doi:10.5194/acp-13-3945-2013, 2013.

Eyring, V., Lamarque, J.-F., Hess, P., Arfeuille, F., Bowman, K., Chipperfield, M. P., Duncan, B., Fiore, A., Gettelman, A., Giorgetta, M. A., Granier, C., Hegglin, M., Kinnison, D., Kunze, M., Langematz, U., Luo, B., Martin, R., Matthes, K., Newman, P. A., Peter, T., Robock, A., Ryerson, T., Saiz-Lopez, A., Salawitch, R., Schultz, M., Shepherd, T. G., Shindell, D., Staehelin, J., Tegtmeier, S., Thomason, L., Tilmes, S., Vernier, J.-P., Waugh, D. W., and Young, P. J.: Overview of IGAC/SPARC Chemistry-Climate Model Initiative (CCMI) community simulations in support of upcoming ozone and climate assessments, SPARC Newsletter, 40, 48-66, 2013a.

Eyring, V., Arblaster, J. M., Cionni, I., Sedláček, J., Perlwitz, J., Young, P. J., Bekki, S., Bergmann, D., Cameron-Smith, P., Collins, W. J., Faluvegi, G., Gottschaldt, K.-D., Horowitz, L. W., Kinnison, D. E., Lamarque, J.-F., Marsh, D. R., Saint-Martin, D., Shindell, D. T., Sudo, K., Szopa, S., and Watanabe, S.: Long-term ozone changes and associated climate impacts in CMIP5 simulations, J. Geophys. Res.-Atmos., 118, 5029-5060, doi:10.1002/jgrd.50316, 2013 b. 
Feichter, J., Kjellström, E., Rodhe, H., Dentener, F., Lelieveld, J., and Roelofs, G.-J.: Simulation of the global sulfur cycle in a global climate model, Atmos. Environ., 30, 1693-1707, 1996.

Feng, W., Chipperfield, M. P., Dhomse, S., Monge-Sanz, B. M., Yang, X., Zhang, K., and Ramonet, M.: Evaluation of cloud convection and tracer transport in a three-dimensional chemical transport model, Atmos. Chem. Phys., 11, 5783-5803, doi:10.5194/acp-11-5783-2011, 2011.

Fouquart, Y. and Bonnel, B.: Computations of solar heating of the Earth' atmosphere: A new parameterization, Beitr. Phys. Atmos., 53, 35-62, 1980.

Garcia, R. R. and Boville, B. A.: Downward control of the mean meridional circulation and temperature distribution of the polar winter stratosphere, J. Atmos. Sci., 51, 2238-2245, 1994.

Garcia, R. R., Smith, A. K., Kinnison, D. E., de la Cámara, Á., and Murphy, D.: Modifications of the gravity wave parameterization in the Whole Atmosphere Community Climate Model: Motivation and results, J. Geophys. Res.-Atmos., doi:10.1175/JAS-D16-0104.1, 2016.

Geleyn, J. F. and Hollingsworth, A.: An economical analytical method for the computation of the interaction between scattering and line absorption of radiation, Contrib. Atmos. Phys., 52, $1-16,1979$.

Giorgetta, M. A.: Der Einfluss der quasi-zweijährigen Oszillation: Modellrechnungen mit ECHAM4, Max-Planck-Institut für Meteorologie, Hamburg, Examensarbeit Nr. 40, MPI-Report 218, 1996.

Giorgetta, M. A. and Bengtsson, L.: Potential role of the quasibiennial oscillation in the stratosphere-troposphere exchange as found in water vapor in general circulation model experiments, J. Geophys. Res., 104, 6003-6019, doi:10.1029/1998JD200112, 1999.

Giorgi, F. and Chameides W. L.: Rainout lifetimes of highly soluble aerosols and gases as inferred from simulations with a general circulation model, J. Geophys. Res., 91, 14367-14376, 1986.

Golaz, J.-C., Salzmann, M., Donner, L. J., Horowitz, L. W., Ming, Y., and Zhao, M.: Sensitivity of the aerosol indirect effect to subgrid variability in the cloud parameterization of the GFDL atmosphere general circulation model AM3, J. Climate, 24, 31453160, 2011.

Golaz, J.-C., Horowitz, L. W., and Levy II, H.: Cloud tuning in a coupled climate model: impact on 20th century warming, Geophys. Res. Lett., 40, 2246-2251, doi:10.1002/grl.50232, 2013.

Granier, C., Bessagnet, B., Bond, T., D’Angiola, A., van der Gon, H. D., Frost, G. J., Heil, A., Kaiser, J. W., and Kinne, S.: Evolution of anthropogenic and biomass burning emissions of air pollutants at global and regional scales during the 1980-2010 period, Clim. Change, 109, 163-190, doi:10.1007/s10584-011-0154-1, 2011.

Grewe, V., Brunner, D., Dameris, M., Grenfell, J. L., Hein, R., Shindell, D., and Staehlin, J.: Origin and variability of upper tropospheric nitrogen oxides and ozone at northern mid-latitudes, Atmos. Environ., 35, 3421-3433, 2001.

Griffies, S. M., Winton, M., Donner, L. J., Horowitz, L. W., Downes, S. M., Farneti, R., Gnanadesikan, A., Hurlin, W. J., Lee, H.C., Liang, Z., Palter, J. B., Samuels, B. L., Wittenberg, A. T., Wyman, B. L., Yin, J., and Zadeh, N.: The GFDL CM3 coupled climate model: characteristics of the ocean and sea ice simulations, J. Climate, 24, 3520-3544, doi:10.1175/2011JCLI3964.1, 2011.
Guenther, A., Baugh, B., Brasseur, G., Greenberg, J., Harley, P., Klinger, L., Serca, D., and Vierling, L.: Isoprene emission estimates and uncertainties for the Central African EXPRESSO study domain, J. Geophys. Res.-Atmos., 104, 30625-30639, doi:10.1029/1999jd900391, 1999.

Guenther, A., Hewitt, C. N., Erickson, D., Fall, R., Geron, C., Graedel, T., Harley, P., Klinger, L., Lerdau, M., Mckay, W. A., Pierce, T., Scholes, B., Steinbrecher, R., Tallamraju, R., Taylor, J., and Zimmerman, P.: A global model of natural volatile organic compound emissions, J. Geophys. Res.-Atmos., 100, 8873-8892, doi:10.1029/94JD02950, 1995.

Guth, J., Josse, B., Marécal, V., Joly, M., and Hamer, P.: First implementation of secondary inorganic aerosols in the MOCAGE version R2.15.0 chemistry transport model, Geosci. Model Dev., 9, 137-160, doi:10.5194/gmd-9-137-2016, 2016.

Hardiman, S. C., Butchart, N., O'Connor, F. M., and Rumbold, S. T.: The Met Office HadGEM3-ES Chemistry-Climate Model: Evaluation of stratospheric dynamics and its impact on ozone, Geosci. Model Dev. Discuss., doi:10.5194/gmd-2016-276, in review, 2016.

Hasumi, H. and Emori, S.: K-1 coupled GCM (MIROC) description, available at: http://ccsr.aori.u-tokyo.ac.jp/hasumi/miroc_ description.pdf, 2004.

Hauglustaine, D. A., Granier, C., Brasseur, G., and Megie, G.: The importance of atmospheric chemistry in the calculation of radiative forcing on the climate system, J. Geophys. Res., 99, 11731186, 1994.

Hegglin, M. I., Lamarque, J.-F., Duncan, B., Eyring, V., Gettelman, A., Hess, P., Myhre, G., Nagashima, T., Plummer, D., Ryerson, T., Shepherd, T., and Waugh, D.: Report on the IGAC/SPARC Chemistry-Climate Model Initiative (CCMI) 2015 science workshop, SPARC Newsletter, 46, 37-42, 2016.

Hewitt, H. T., Copsey, D., Culverwell, I. D., Harris, C. M., Hill, R. S. R., Keen, A. B., McLaren, A. J., and Hunke, E. C.: Design and implementation of the infrastructure of HadGEM3: the nextgeneration Met Office climate modelling system, Geosci. Model Dev., 4, 223-253, doi:10.5194/gmd-4-223-2011, 2011.

Hines, C. O.: Doppler spread parameterization of gravity wave momentum deposition in the middle atmosphere, 2, Broad and quasi monochromatic spectra and implementation, J. Atmos. Sol.-Terr. Phy., 59, 387-400, 1997.

Holtslag, A. and Boville, B.: Local versus nonlocal boundary layer diffusion in a global climate model, J. Climate, 6, 1825-1842, 1993.

Horowitz, L. W., Fiore, A. M., Milly, G. P., Cohen, R. C., Perring, A., Wooldridge, P. J., Hess, P. G., Emmons, L. K., and Lamarque, J.-F.: Observational constraints on the chemistry of isoprene nitrates over the eastern United States, J. Geophys. Res., 112, D12S08, doi:10.1029/2006JD007747, 2007.

Hourdin, F., Musat, I., Bony, S., Braconnot, P., Codron, F., Dufresne, J. L., Fairhead, L., Filiberti, M. A., Friedlingstein, P., Grandpeix, J. Y., Krinner, G., Levan, P., Li, Z. X., and Lott, F.: The LMDZ4 general circulation model: Climate performance and sensitivity to parametrized physics with emphasis on tropical convection, Clim. Dynam., 27, 787-813, 2006.

Hunke, E. C. and Lipscombe, W. H.: CICE: the Los Alamos sea ice model documentation and software user's manual, Version 4.0, LA-CC-06-012, Los Alamos National Laboratory, New Mexico, 2008. 
IPCC: Climate Change 2007: Synthesis Report, Contribution of Working Groups I, II and III to the Fourth Assessment Report of the Intergovernmental Panel on Climate Change, edited by: Core Writing Team, Pachauri, R. K., and Reisinger, A., IPCC, Geneva, Switzerland, 104 pp., 2007.

IPCC: Climate Change 2013: The Physical Science Basis, Contribution of Working Group I to the Fifth Assessment Report of the Intergovernmental Panel on Climate Change, edited by: Stocker, T. F., Qin, D., Plattner, G.-K., Tignor, M., Allen, S. K., Boschung, J., Nauels, A., Xia, Y., Bex, V., and Midgley, P. M., Cambridge University Press, Cambridge, UK, New York, NY, USA, 1535 pp., 2013.

Imai, K., Manago, N., Mitsuda, C., Naito, Y.,. Nishimoto, E, Sakazaki, T., Fujiwara, M., Froidevaux, L., von Clarmann, T., Stiller, G. P., Murtagh, D. P., Rong, P.-P., Mlynczak, M. G., Walker, K. A., Kinnison, D. E., Akiyoshi, H., Nakamura, T., Miyasaka, T., Nishibori, T., Mizobuchi, S., Kikuchi, K., Ozeki, H., Takahashi, C., Hayashi, H., Sano, T., Suzuki, M., Takayanagi, M., and Shiotani, M.: Validation of ozone data from the Superconducting Submillimeter-Wave Limb-Emission Sounder (SMILES), J. Geophys. Res.-Atmos., 118, 5750-5769, doi:10.1002/jgrd.50434, 2013.

Iwasaki, T., Yamada, S., and Tada, K.: A parameterization scheme of orographic gravity wave drag with the different vertical partitioning, Part 1: Impact on medium range forecast, J. Meteorol. Soc. Jpn., 67, 11-41, 1989.

Jackman, C., Marsh, D., Vitt, F., Garcia, R., Randall, C., Fleming, E., and Frith, S.: Long-term middle atmosphere influence of very large solar proton events, J. Geophys. Res., 114, D11304, doi:10.1029/2008JD011415, 2009.

Jöckel, P., Sander, R., Kerkweg, A., Tost, H., and Lelieveld, J.: Technical Note: The Modular Earth Submodel System (MESSy) - a new approach towards Earth System Modeling, Atmos. Chem. Phys., 5, 433-444, doi:10.5194/acp-5-433-2005, 2005.

Jöckel, P., Tost, H., Pozzer, A., Brühl, C., Buchholz, J., Ganzeveld, L., Hoor, P., Kerkweg, A., Lawrence, M. G., Sander, R., Steil, B., Stiller, G., Tanarhte, M., Taraborrelli, D., van Aardenne, J., and Lelieveld, J.: The atmospheric chemistry general circulation model ECHAM5/MESSy1: consistent simulation of ozone from the surface to the mesosphere, Atmos. Chem. Phys., 6, 50675104, doi:10.5194/acp-6-5067-2006, 2006.

Jöckel, P., Kerkweg, A., Pozzer, A., Sander, R., Tost, H., Riede, H., Baumgaertner, A., Gromov, S., and Kern, B.: Development cycle 2 of the Modular Earth Submodel System (MESSy2), Geosci. Model Dev., 3, 717-752, doi:10.5194/gmd-3-717-2010, 2010.

Jöckel, P., Tost, H., Pozzer, A., Kunze, M., Kirner, O., Brenninkmeijer, C. A. M., Brinkop, S., Cai, D. S., Dyroff, C., Eckstein, J., Frank, F., Garny, H., Gottschaldt, K.-D., Graf, P., Grewe, V., Kerkweg, A., Kern, B., Matthes, S., Mertens, M., Meul, S., Neumaier, M., Nützel, M., Oberländer-Hayn, S., Ruhnke, R., Runde, T., Sander, R., Scharffe, D., and Zahn, A.: Earth System Chemistry integrated Modelling (ESCiMo) with the Modular Earth Submodel System (MESSy) version 2.51, Geosci. Model Dev., 9, 1153-1200, doi:10.5194/gmd-9-1153-2016, 2016.

John, J. G., Fiore, A. M., Naik, V., Horowitz, L. W., and Dunne, J. P.: Climate versus emission drivers of methane lifetime against loss by tropospheric OH from 1860-2100, Atmos. Chem. Phys., 12, 12021-12036, doi:10.5194/acp-12-12021-2012, 2012.
Jonsson, A. I., de Grandpré, J., Fomichev, V. I., McConnell, J. C., and Beagley, S. R.: Doubled $\mathrm{CO}_{2}$-induced cooling in the middle atmosphere: Photochemical analysis of the ozone radiative feedback, J. Geophys. Res, 109, D24103, doi:10.1029/2004JD005093, 2004.

Josse, B., Simon, P., and Peuch, V.-H.: Radon global simulations with the multiscale chemistry and transport model MOCAGE, Tellus B, 56, 339-356, 2004.

Kärcher, B. and Lohmann, U.: A parameterization of cirrus cloud formation: homogeneous freezing of supercooled aerosols, J. Geophys. Res., 107, 4010, doi:10.1029/2001JD000470, 2002.

Kerkweg, A., Buchholz, J., Ganzeveld, L., Pozzer, A., Tost, H., and Jöckel, P.: Technical Note: An implementation of the dry removal processes DRY DEPosition and SEDImentation in the Modular Earth Submodel System (MESSy), Atmos. Chem. Phys., 6, 4617-4632, doi:10.5194/acp-6-4617-2006, 2006a.

Kerkweg, A., Sander, R., Tost, H., and Jöckel, P.: Technical note: Implementation of prescribed (OFFLEM), calculated (ONLEM), and pseudo-emissions (TNUDGE) of chemical species in the Modular Earth Submodel System (MESSy), Atmos. Chem. Phys., 6, 3603-3609, doi:10.5194/acp-6-3603-2006, 2006b.

Kettle, A. J., Andreae, M. O., Amouroux, D., Andreae, T. W., Bates, T. S., Berresheim, H., Bingemer, H., Boniforti, R., Curran, M. A. J., DiTullio, G. R., Helas, G., Jones, G. B., Keller, M. D., Kiene, R. P., Leck, C., Levasseur, M., Malin, G., Maspero, M., Matrai, P., McTaggart, A. R., Mihalopoulos, N., Nguyen, B. C., Novo, A., Putaud, J. P., Rapsomanikis, S., Roberts, G., Schebeske, G., Sharma, S., Simó, R., Staubes, R., Turner, S., and Uher, G.: A global database of sea surface dimethylsulfide (DMS) measurements and a procedure to predict sea surface DMS as a function of latitude, longitude, and month, Glob. Biogeochem. Cy., 13, 399-444, doi:10.1029/1999GB900004, 1999.

Kreidenweis, S. M., Walcek, C. J., Feingold, G., Gong, W. M., Jacobson, M. Z., Kim, C. H., Liu, X. H., Penner, J. E., Nenes, A., and Seinfeld, J. H.: Modification of aerosol mass and size distribution due to aqueous-phase $\mathrm{SO}_{2}$ oxidation in clouds: Comparisons of several models, J. Geophys. Res.-Atmos., 108, 4213, doi:10.1029/2002JD002697, 2003.

Kirner, O., Ruhnke, R., Buchholz-Dietsch, J., Jöckel, P., Brühl, C. and Steil, B.: Simulation of polar stratospheric clouds in the chemistry-climate-model EMAC via the submodel PSC, Geosci. Model Dev., 4, 169-182, doi:10.5194/gmd-4-169-2011, 2011.

Krivova, N., Solanki, S., and Floyd, L.: Reconstruction of solar UV irradiance in cycle 23, Astron. Astrophys., 452, 631-639, 2006.

Kunze, M., Godolt, M., Langematz, U., Grenfell, J., HamannReinus, A., and Rauer, H.: Investigating the early Earth faint young Sun problem with a general circulation model, Planet. Space Sci., 98, 77-92, doi:10.1016/j.pss.2013.09.011, 2014.

Koster, R. D., Suarez, M. J., Ducharne, A., Stieglitz, M., and Kumar, P.: A catchment-based approach to modeling land surface processes in a GCM: 1. Model structure, J. Geophys. Res., 105, 24809-24822, doi:10.1029/2000JD900327, 2000.

Kurokawa, J., Akiyoshi, H.,, Nagashima, Masunaga, H.,, Nagajima, Takahashi, and Nakane, H.: Effects of atmospheric sphericity on stratospheric chemistry and dynamics over Antarctica, J. Geophys. Res., 110, D21305, doi:10.1029/2005JD005798, 2005.

Lamarque, J.-F., Bond, T. C., Eyring, V., Granier, C., Heil, A., Klimont, Z., Lee, D., Liousse, C., Mieville, A., Owen, B., Schultz, M. G., Shindell, D., Smith, S. J., Stehfest, E., Van Aar- 
denne, J., Cooper, O. R., Kainuma, M., Mahowald, N., McConnell, J. R., Naik, V., Riahi, K., and van Vuuren, D. P.: Historical (1850-2000) gridded anthropogenic and biomass burning emissions of reactive gases and aerosols: methodology and application, Atmos. Chem. Phys., 10, 7017-7039, doi:10.5194/acp10-7017-2010, 2010.

Lamarque, J.-F., Shindell, D. T., Josse, B., Young, P. J., Cionni, I., Eyring, V., Bergmann, D., Cameron-Smith, P., Collins, W. J., Doherty, R., Dalsoren, S., Faluvegi, G., Folberth, G., Ghan, S. J., Horowitz, L. W., Lee, Y. H., MacKenzie, I. A., Nagashima, T., Naik, V., Plummer, D., Righi, M., Rumbold, S. T., Schulz, M., Skeie, R. B., Stevenson, D. S., Strode, S., Sudo, K., Szopa, S., Voulgarakis, A., and Zeng, G.: The Atmospheric Chemistry and Climate Model Intercomparison Project (ACCMIP): overview and description of models, simulations and climate diagnostics, Geosci. Model Dev., 6, 179-206, doi:10.5194/gmd-6-179-2013, 2013.

Lary, D. J. and Pyle, J. A.: Diffuse radiation, twilight, and photochemistry- I, J. Atmos. Chem., 13, 373-392, 1991.

Lean, J., Rottman, G., Harder, J., and Kopp, G.: SORCE contributions to new understanding of global change and solar variability, Solar Phys., 230, 27-53, 2005.

Lefèvre, F., Brasseur, G. P., Folkins, I., Smith, A. K., and Simon, P.: Chemistry of the 1991-1992 stratospheric winter: threedimensional model simulations, J. Geophys. Res., 99, 8183-8195, doi:10.1029/93JD03476, 1994.

Lefèvre, F., Figarol, F., Carslaw, K. S., and Peter, T.: The 1997 Arctic ozone depletion quantified from three-dimensional model simulations, Geophys. Res. Lett., 25, 2425-2428, doi:10.1029/98GL51812, 1998.

Levy II, H., Horowitz, L. W., Schwarzkopf, M. D., Ming, Y., Golaz, J.-C., Naik, V., and Ramaswamy, V.: The roles of aerosol direct and indirect effects in past and future climate change, J. Geophys. Res., 118, 4521-4532, doi:10.1002/jgrd.50192, 2013.

Lin, S.-J.: A “vertically-Lagrangian” finite-volume dynamical core for global atmospheric models, Mon. Weather Rev., 132, 22932307, 2004.

Lin, M., Fiore, A. M., Horowitz, L. W., Cooper, O. R., Naik, V., Holloway, J., Johnson, B. J., Middlebrook, A. M., Oltmans, S. J., Pollack, I. B., Ryerson, T. B., Warner, J. X., Wiedinmyer, C., Wilson, J., and Wyman, B.: Transport of Asian ozone pollution into surface air over the western United States in spring, J. Geophys. Res., 117, D00V07, doi:10.1029/2011jd016961, 2012a.

Lin, M., Fiore, A. M., Cooper, O. R., Horowitz, L. W., Langford, A. O., Levy, H., Johnson, B. J., Naik, V., Oltmans, S. J., and Senff, C. J.: Springtime high surface ozone events over the western United States: Quantifying the role of stratospheric intrusions, J. Geophys. Res., 117, D00V22, doi:10.1029/2012jd018151, 2012b.

Lin, M., Horowitz, L. W., Oltmans, S. J., Fiore, A. M., and Fan, S.: Tropospheric ozone trends at Mauna Loa Observatory tied to decadal climate variability, Nat. Geosci., 7, 136-143, doi:10.1038/ngeo2066, 2014.

Lin, M., Fiore, A. M., Horowitz, L. W., Langford, A. O., Oltmans, S. J., Tarasick, D., and Rieder, H. E.: Climate variability modulates western US ozone air quality in spring via deep stratospheric intrusions, Nature Comm., 6, 7105, doi:10.1038/ncomms8105, 2015a.
Lin, M., Horowitz, L. W., Cooper, O. R., Tarasick, D., Conley, S., Iraci, L. T., Johnson, B., Leblanc, T., Petropavlovskikh, I., and Yates, E. L.: Revisiting the evidence of increasing springtime ozone mixing ratios in the free troposphere over western North America, Geophys. Res. Lett., 42, 8719-8728, doi:10.1002/2015GL065311, 2015b.

Lin, S.-J. and Rood, R. B.: Multidimensional fluxform semi-Lagrangian transport schemes, Mon. Weather Rev., 124, 2046-2070, doi:10.1175/15200493(1996)124<2046:MFFSLT>2.0.CO;2, 1996.

Liss, P. and Slater, P.: Flux of gases across the air-sea interface, Nature, 247, 181-184, doi:10.1038/247181a0, 1974.

Liu, J., Fan, S.-M., Horowitz, L. W., and Levy II, H.: Evaluation of factors controlling long-range transport of black carbon to the Arctic, J. Geophys. Res., 116, D04307, doi:10.1029/2010JD015145, 2011.

Lock, A. P., Brown, A. R., Bush, M. R., Martin, G. M., and Smith, R. N. B.: A new boundary layer mixing scheme, Part I: Scheme description and single-column model tests, Mon. Weather Rev., 138, 3187-3199, 2000

Lohmann, U. and Roeckner, E.: Design and performance of a new cloud microphysics parameterization developed for the ECHAM4 general circulation model, Clim. Dynam., 12, 557$572,1996$.

Lott, F.: Alleviation of stationary biases in a GCM through a mountain drag parameterization scheme and a simple representation of mountain lift forces, Mon. Weather Rev., 127, 788-801, 1999. odel, Clim. Dynam., 12, 557-572, 1996.

Lott, F. and Guez, L.: A stochastic parameterization of the gravity waves due to convection and its impact on the equatorial stratosphere, J. Geophys. Res.-Atmos., 118, 8897-8909, doi:10.1002/jgrd.50705, 2013.

Lott, F. and Miller, M. J.: A new-subgrid-scale orographic drag parameterization: Its formulation and testing, Q. J. Roy. Meteorol Soc., 123, 101-112, 1997.

Lott, F., Fairhead, L., Hourdin, F., and Levan, P.: The stratospheric version of LMDz: dynamical climatologies, Arctic Oscillation, and impact on the surface climate, Clim. Dynam., 25, 851-868, 2005.

Louis, J.-F., Tiedtke, M., and Geleyn, J.-F.: A short history of the PBL parameterization at ECMWF, Proc. ECMWF Workshop on Planetary Boundary Layer Parameterization, 25-27 November 1981, Reading, UK, ECMWF, 1982.

Madec, G.: NEMO ocean engine, Institut Piere-Simon Laplace (IPSL), France, No. 27, ISSN No. 1288-1619, 2008.

Madronich, S. and Flocke, S.: The role of solar radiation in atmospheric chemistry, Springer-Verlag, New York, 1-26, 1998.

Manzini, E., McFarlane, N. A., and McLandress, C.: Impact of the Doppler spread parameterization on the simulation of the middle atmosphere circulation using the MA/ECHAM4 general circulation model, J. Geophys. Res., 102, 25751-25762, doi:10.1029/97JD01096, 1997.

Manzini, E., Giorgetta, M. A., Esch, M., Kornblueh, L., and Roeckner, E.: The influence of sea surface temperatures on the northern winter stratosphere: ensemble simulations with the MAECHAM5 model, J. Climate, 19, 3863-3881, 2006.

Marchand M., Keckhut, P., Lefebvre, S., Claud, C., Cugnet, D., Hauchecorne, A., Lefèvre, F., Jumelet, J., Lott, F., Hourdin, F., Thuillier, G., Poulain, V., Bossay, S., Lemennais, P., David, C., 
and Bekki, S.: Dynamical amplification of the stratospheric solar response simulated with the chemistry-climate model LMDzREPROBUS, J. Atmos. Sol.-Terr. Phy., 75-76, 147-160, 2012.

Mari, C., Jacob, D. J., and Bechtold, P.: Transport and scavenging of soluble gases in a deep convective cloud, J. Geophys. Res., 105, 22255-22267, doi:10.1029/2000JD900211, 2000.

Marsh, D., Mills, M. J., Kinnison, D. E., Garcia, R. R., Lamarque, J.-F., and Calvo, N.: Climate change from 1850-2005 simulated in CESM1 (WACCM), J. Climate, 26, 7372-7391, doi:10.1175/JCLI-D-12-00558.1, 2013.

Marti, O., Braconnot, P., Dufresne, J.-L., Bellier, J., Benshila, R., Bony, S., Brockmann, P., Cadule, P., Caubel, A., Codron, F., de Noblet, N., Denvil, S., Fairhead, L., Fichefet, T., Foujols, M.A., Friedlingstein, P., Goosse, H., Grandpeix, J.-Y., Guilyardi, E., Hourdin, F., Idelkadi, A., Kageyama, M., Krinner, G., Levy, C., Madec, G., Mignot, J., Musat, I., Swingedouw, D., and Talandier, C.: Key features of the IPSL ocean atmosphere model and its sensitivity to atmospheric resolution, Clim. Dynam., 34, 1-26, doi:10.1007/s00382-009-0640-6, 2010.

Martin, G. M., Ringer, M. A., Pope, V. D., Jones, A., Dearden, C., and Hinton, T. J.: The physical properties of the atmosphere in the new Hadley Centre Global Environmental Model, HadGEM1, Part 1: Model description and global climatology, J. Climate, 19, 1274-1301, doi:10.1175/JCLI3636.1, 2006.

Mascart P., Noilhan, J., and Giordani, H.: A modified parameterization of flux profile relationships in the surface layer using different roughness length values for heat and momentum, Bound.Lay. Meteorol., 72, 331-344, 1995.

McCalpin, J. D.: A quantitative analysis of the dissipation inherent in semi-Lagrangian advection, Mon. Weather Rev., 116, 2330-2336, doi:10.1175/15200493(1988)116<2330:AQAOTD>2.0.CO;2, 1988.

McFarlane, N. A.: The effect of orographically excited gravity wave drag on the general circulation of the lower stratosphere and troposphere, J. Atmos. Sci., 44, 1775-1800, 1987.

McLandress, C., Plummer, D. A., and Shepherd, T. G.: Technical Note: A simple procedure for removing temporal discontinuities in ERA-Interim upper stratospheric temperatures for use in nudged chemistry-climate model simulations, Atmos. Chem. Phys., 14, 1547-1555, doi:10.5194/acp-14-1547-2014, 2014.

Meehl, G. A., Washington, W. M., Arblaster, J. M., Hu, A., Teng, H., Kay, J. E., Gettelman, A., Lawrence, D. M., Sanderson, B. M., and Strand, W. G.: Climate change projections in CESM1(CAM5) compared to CCSM4, J. Climate, 26, 62876308, doi:10.1175/JCLI-D-12-00572.1, 2013.

Meinshausen, M., Smith, S. J., Calvin, K., Daniel, J. S., Kainuma, M. L., Lamarque, J.-F., Matsumoto, K., Montzka, S. A., Raper, S. C., Riahi, K., Thomson, A., Velders, G. J., and van Vuuren, D. P.: The RCP greenhouse gas concentrations and their extensions from 1765 to 2300, Clim. Change, 109, 213-241, doi:10.1007/s10584-011-0156-z, 2011.

Michou, M., Saint-Martin, D., Teyssèdre, H., Alias, A., Karcher, F., Olivié, D., Voldoire, A., Josse, B., Peuch, V.-H., Clark, H., Lee, J. N., and Chéroux, F.: A new version of the CNRM ChemistryClimate Model, CNRM-CCM: description and improvements from the CCMVal-2 simulations, Geosci. Model Dev., 4, 873900, doi:10.5194/gmd-4-873-2011, 2011.

Minschwaner, K., Salawitch, R. J., and McElroy, M. B.: Absorption of solar radiation by $\mathrm{O}_{2}$ : Implications for $\mathrm{O}_{3}$ and lifetimes of
$\mathrm{N}_{2} \mathrm{O}, \mathrm{CFCl}_{3}$, and $\mathrm{CF}_{2} \mathrm{Cl}_{2}$, J. Geophys. Res., 98, 10543-10561, 1993.

Mlawer, E. J., Taubman, S. J., Brown, P. D., Iacono, M. J., and Clough, S. A.: Radiative transfer for inhomogeneous atmospheres: RRTM, a validated $k$-correlated model for the longwave, J. Geophys. Res., 102, 16663-16682, 1997.

Molod, A., Takacs, L., Suarez, M., Bacmeister, J., Song, I.-S., and Eichmann, A.: The GEOS-5 Atmospheric General Circulation Model: Mean Climate and Development from MERRA to Fortuna, NASA Technical Report Series on Global Modeling and Data Assimilation, NASA TM-2012-104606, 28, 117 pp., 2012.

Molod, A., Takacs, L., Suarez, M., and Bacmeister, J.: Development of the GEOS-5 atmospheric general circulation model: evolution from MERRA to MERRA2, Geosci. Model Dev., 8, 1339-1356, doi:10.5194/gmd-8-1339-2015, 2015.

Monks, S. A., Arnold, S. R., and Chipperfield, M. P.: Evidence for El Niño-Southern Oscillation (ENSO) influence on Arctic CO interannual variability through biomass burning emissions, Geophys. Res. Lett., 39, L14804, doi:10.1029/2012GL052512, 2012.

Moorthi, S. and Suarez, M. J.: Relaxed Arakawa Schubert: A parameterization of moist convection for general circulation models, Mon. Weather Rev., 120, 978-1002, 1992.

Morcrette, J.-J.: Impact of changes to the radiation transfer parameterizations plus cloud optical properties in the ECMWF model, Mon. Weather Rev., 118, 847-873, 1990.

Morcrette, J.-J.: Radiation and cloud radiative properties in the European Center for Medium-Range Weather Forecasts forecasting system, J. Geophys. Res., 95, 9121-9132, 1991.

Morcrette J.-J., Mlawer, E. J., Iacono, M. J., and Clough, S. A.: Impact of the radiation-transfer scheme RRTM in the ECMWF forecasting system, ECMWF Newsletter No. 91, 2001.

Morgenstern, O., Braesicke, P., O’Connor, F. M., Bushell, A. C., Johnson, C. E., Osprey, S. M., and Pyle, J. A.: Evaluation of the new UKCA climate-composition model - Part 1: The stratosphere, Geosci. Model Dev., 2, 43-57, doi:10.5194/gmd-2-432009, 2009.

Morgenstern, O., Giorgetta, M. A., Shibata, K., Eyring, V., Waugh, D. W., Shepherd, T. G., Akiyoshi, H., Austin, J., Baumgaertner, A. J. G., Bekki, S., Braesicke, P., Brühl, C., Chipperfield, M. P., Cugnet, D., Dameris, M., Dhomse, S. S., Frith, S., Garny, H., Gettelman, A., Hardiman, S. C., Hegglin, M. I., Jöckel, P., Kinnison, D. E., Lamarque, J.-F., Mancini, E., Manzini, E., Marchand, M., Michou, M., Nakamura, T., Nielsen, J. E., Olivié, D., Pitari, G., Plummer, D. A., Rozanov, E., Scinocca, J., Smale, D., Teyssèdre, H., Toohey, M., Tian, W., and Yamashita, Y. : Review of the formulation of present-generation chemistry-climate models and associated forcings, J. Geophys. Res., 115, D00M02, doi:10.1029/2009JD013728, 2010.

Morgenstern, O., Zeng, G., Abraham, N. L., Telford, P. J., Braesicke, P., Pyle, J. A., Hardiman, S. C., O’Connor, F. M., and Johnson, C. E.: Impacts of climate change, ozone recovery, and increasing methane on surface ozone and the tropospheric oxidizing capacity, J. Geophys. Res.-Atmos., 118, 1028-1041, doi:10.1029/2012JD018382, 2013.

Morgenstern, O., Zeng, G., Dean, S. M., Joshi, M., Abraham, N. L., and Osprey, A.: Direct and ozone mediated forcing of the Southern Annular Mode by greenhouse gases, Geophys. Res. Lett., 41, 9050-9057, doi:10.1002/2014GL062140, 2014. 
Müller, J.-F. and Brasseur, G.: IMAGES: A three dimensional chemical transport model of the global troposphere, J. Geophys. Res., 100, 16445-16490, 1995.

Naik, V., Horowitz, L. W., Fiore, A. M., Ginoux, P., Mao, J. Q., Aghedo, A. M., and Levy, H.: Impact of preindustrial to presentday changes in short-lived pollutant emissions on atmospheric composition and climate forcing, J. Geophys. Res., 118, 80868110, doi:10.1002/jgrd.50608, 2013.

Nakajima, T. and Tanaka, M.: Matrix formulation for the transfer of solar radiation in a plane-parallel scattering atmosphere, $\mathrm{J}$. Quant. Spectrosc. Ra., 35, 13-21, 1986.

Nakajima, T., Tsukamoto, M., Tsuhima, Y., Numaguti, A., and Kimura, T.: Modeling of the radiative process in an atmospheric general circulation model, Appl. Opt., 39, 4869-4878, 2000.

Neale, R. B., Richter, J., Park, S., Lauritzen, P. H., Vavrus, S. J., Rasch, P. J., and Zhang, M.: The mean climate of the Community Atmosphere Model (CAM4) in forced SST and fully coupled experiments, J. Climate, 26, 5150-5168, doi:10.1175/JCLI-D-1200236.1, 2013.

Noilhan, J. and Planton, S.: A simple parameterization of land surface processes for meteorological models, Mon. Weather Rev., 117, 536-549, 1989.

Noh, Y. and Kim, H.-J.: Simulations of temperature and turbulence structure of the oceanic boundary layer with the improved nearsurface process, J. Geophys. Res., 104, 15621-15634, 1999.

Nordeng, T. E.: Extended versions of the convection parametrization scheme at ECMWF and their impact on the mean and transient activity of the model in the tropics, ECMWF Tech. Memo. 206, ECMWF, Reading, UK, 1994.

Neu, J. L., Prather, M. J., and Penner, J. E.: Global atmospheric chemistry: Integrating over fractional cloud cover, J. Geophys. Res., 112, D11306, doi:10.1029/2006JD008007, 2007.

Numaguti, A., Takahashi, M., Nakajima, T., and Sumi, A.: Description of CCSR/NIES Atmospheric General Circulation Model, CGER's Supercomputer Monograph Report, Center for Global Environmental Reserch, National Institute for Environmental Studies, 3, 48 pp., 1997.

O’Connor, F. M., Johnson, C. E., Morgenstern, O., Abraham, N. L., Braesicke, P., Dalvi, M., Folberth, G. A., Sanderson, M. G., Telford, P. J., Voulgarakis, A., Young, P. J., Zeng, G., Collins, W. J., and Pyle, J. A.: Evaluation of the new UKCA climatecomposition model - Part 2: The Troposphere, Geosci. Model Dev., 7, 41-91, doi:10.5194/gmd-7-41-2014, 2014.

Oman, L. D., Ziemke, J. R., Douglass, A. R., Waugh, D. W., Lang, C., Rodriguez, J. M., and Nielsen, J. E.: The response of tropical tropospheric ozone to ENSO, Geophys. Res. Lett., 38, L13706, doi:10.1029/2011GL047865, 2011.

Oman, L. D., Douglass, A. R., Ziemke, J. R., Rodriguez, J. M., Waugh, D. W., and Nielsen, J. E.: The ozone response to ENSO in Aura satellite measurements and a chemistry-climate simulation, J. Geophys. Res., 118, 965-976, doi:10.1029/2012JD018546, 2013.

Pan, D.-M. and Randall, D. A.: A cumulus parameterization with a prognostic closure, Q. J. Roy. Meteorol. Soc., 124, 949-981, 1998.

Pitari, G., Aquila, V., Kravitz, B., Robock, A., Watanabe, S., Cionni, I., De Luca, N., Di Genova, G., Mancini, E., and Tilmes, S.: Stratospheric ozone response to sulfate geoengineering: Results from the Geoengineering Model Intercompar- ison Project (GeoMIP), J. Geophys. Res., 119, 2629-2653, doi:10.1002_2013JD020566, 2014.

Pitari, G., Iachetti, D., Di Genova, G., De Luca, N., Søvde, O. A., Hodnebrog, Ø., Lee, D. S., and Lim, L.: Impact of coupled $\mathrm{NO}_{x}$ /aerosol aircraft emissions on ozone photochemistry and radiative forcing, Atmosphere, 6, 751-782; doi:10.3390/atmos6060751, 2015a.

Pitari, G., Di Genova, G., and De Luca, N.: A modelling study of the impact of on-road diesel emissions on Arctic black carbon and solar radiation transfer, Atmosphere, 6, 318-340, doi:10.3390/atmos6030318, 2015b

Pitari, G., Di Genova, G., Coppari, E., De Luca, N., Di Carlo, P., Iarlori, M., and Rizi, V.: Desert dust transported over Europe: Lidar observations and model evaluation of the radiative impact, J. Geophys. Res., 120, 2881-2898, doi:10.1002/2014JD022875, 2015c.

Pitari, G., Di Genova, G., Mancini, E., Visioni, D., Gandolfi, I., and Cionni, I.: Stratospheric aerosols from major volcanic eruptions: a composition-climate model study of the aerosol cloud dispersal and e-folding time, Atmosphere, 7, 75, doi:10.3390/atmos7060075, 2016a.

Pitari, G., Cionni, I., Di Genova, G., Visioni, D., Gandolfi, I., and Mancini, E.: Impact of stratospheric volcanic aerosols on ageof-air and transport of long-lived species, Atmosphere, 7, 149, doi:10.3390/atmos7110149, 2016b.

Pitari G., Visioni, D., Mancini, E., Cionni, I., Di Genova, G., and Gandolfi, I.: Sulfate aerosols from non-explosive volcanoes: chemical-radiative effects in the troposphere and lower stratosphere, Atmosphere, 7, 85, doi:10.3390/atmos7070085, 2016c.

Pöschl, U., von Kuhlmann, R., Poisson, N., and Crutzen, P. J.: Development and intercomparison of condensed isoprene oxidation mechanisms for global atmospheric modeling, J. Atmos. Chem., 37, 29-52, 2000.

Pozzer, A., Jöckel, P., Sander, R., Williams, J., Ganzeveld, L., and Lelieveld, J.: Technical Note: The MESSy-submodel AIRSEA calculating the air-sea exchange of chemical species, Atmos. Chem. Phys., 6, 5435-5444, doi:10.5194/acp-6-5435-2006, 2006.

Pozzer, A., Jöckel, P., Kern, B., and Haak, H.: The AtmosphereOcean General Circulation Model EMAC-MPIOM, Geosci. Model Dev., 4, 771-784, doi:10.5194/gmd-4-771-2011, 2011.

Prather, M. (1986), Numerical advection by conservation of secondorder moments., J. Geophys. Res., 91, 6671-6681.

Price, C. and Rind, D.: A simple lightning parameterization for calculating global lightning distributions, J. Geophys. Res., 97, 9919-9933, doi:10.1029/92JD00719, 1992.

Price, C. and Rind, D.: Modeling global lightning distributions in a general circulation model, Mon. Weather Rev., 122, 1930-1939, doi:doi:10.1175/15200493(1994)122<1930:MGLDIA>2.0.CO;2, 1994.

Price, C., Penner, J., and Prather, M.: $\mathrm{NO}_{x}$ from lightning: 1. Global distribution based on lightning physics, J. Geophys. Res., 102, 5929-5941, doi:10.1029/96JD03504, 1997.

Priestley, A.: A quasi-conservative version of the semi-Lagrangian advection scheme, Mon. Weather Rev., 121, 621-629, doi:doi:10.1175/15200493(1993)121<0621:AQCVOT>2.0.CO;2, 1993.

Putman, W. M. and Lin, S.-J.: Finite-volume transport on various cubed-sphere grid, J. Comput. Phys., 227, 55-78, 2007. 
Randles, C. A., Kinne, S., Myhre, G., Schulz, M., Stier, P., Fischer, J., Doppler, L., Highwood, E., Ryder, C., Harris, B., Huttunen, J., Ma, Y., Pinker, R. T., Mayer, B., Neubauer, D., Hitzenberger, R., Oreopoulos, L., Lee, D., Pitari, G., Di Genova, G., Quaas, J., Rose, F. G., Kato, S., Rumbold, S. T., Vardavas, I., Hatzianastassiou, N., Matsoukas, C., Yu, H., Zhang, F., Zhang, H., and $\mathrm{Lu}$, P.: Intercomparison of shortwave radiative transfer schemes in global aerosol modeling: results from the AeroCom Radiative Transfer Experiment, Atmos. Chem. Phys., 13, 2347-2379, doi:10.5194/acp-13-2347-2013, 2013.

Rayner, N. A., Parker, D. E., Horton, E. B., Folland, C. K., Alexander, L. V., Rowell, D. P., Kent, E. C., and Kaplan, A.: Global analyses of sea surface temperature, sea ice, and night marine air temperature since the late nineteenth century, J. Geophys. Res., 108, 4407, doi:10.1029/2002JD002670, 2003.

Revell, L. E., Tummon, F., Stenke, A., Sukhodolov, T., Coulon, A., Rozanov, E., Garny, H., Grewe, V., and Peter, T.: Drivers of the tropospheric ozone budget throughout the 21 st century under the medium-high climate scenario RCP 6.0, Atmos. Chem. Phys., 15, 5887-5902, doi:10.5194/acp-15-5887-2015, 2015.

Ricard, J.-L. and Royer, J.-F.: A statistical cloud scheme for use in a AGCM, Ann. Geophys., 11, 1095-1115, 1993.

Roeckner, E., Bäuml, G., Bonaventura, L., Brokopf, R., Esch, M., Giorgetta, M., Hagemann, S., Kirchner, I., Kornblueh, L., Manzini, E., Rhodin, A., Schlese, U., Schulzweida, U., and Tompkins, A.: The atmospheric general circulation model ECHAM 5, Part I: Model description, Max-PlanckInstitut für Meteorologie, Hamburg, Report No. 349, available at: http://www.mpimet.mpg.de/fileadmin/publikationen/Reports/ max_scirep_349.pdf, 2003.

Riahi, K., Rao, S., Krey, V., Cho, C., Chirkov, V., Fischer, G., Kindermann, G., Nakicenovic, N., and Rafa, P.: RCP 8.5 - A scenario of comparatively high greenhouse gas emissions, Clim. Change, 109, 33, doi:10.1007/s10584-011-0149-y, 2011

Righi, M., Hendricks, J., and Sausen, R.: The global impact of the transport sectors on atmospheric aerosol: simulations for year 2000 emissions, Atmos. Chem. Phys., 13, 9939-9970, doi:10.5194/acp-13-9939-2013, 2013.

Roeckner, E., Brokopf, R., Esch, M., Giorgetta, M., Hagemann, S., Kornblueh, L., Manzini, E., Schlese, U., and Schulzweida, U.: Sensitivity of simulated climate to horizontal and vertical resolution in the ECHAM5 atmosphere model, J. Climate, 19, 37713791, 2006.

Rozanov, E., Schlesinger, M. E., Zubov, V., Yang, F., and Andronova, N. G.: The UIUC three-dimensional stratospheric chemical transport model: Description and evaluation of the simulated source gases and ozone, J. Geophys. Res., 104, 1175511781, 1999.

Rozanov, E., Calisto, M., Egorova, T., Peter, T., and Schmutz, W.: Influence of the precipitating energetic particles on atmospheric chemistry and climate, Surv. Geophys., 33, 483-501, doi:10.1007/s10712-012-9192-0, 2012.

Sander, R., Baumgaertner, A., Gromov, S., Harder, H., Jöckel, P., Kerkweg, A., Kubistin, D., Regelin, E., Riede, H., Sandu, A., Taraborrelli, D., Tost, H., and Xie, Z.-Q.: The atmospheric chemistry box model CAABA/MECCA-3.0, Geosci. Model Dev., 4, 373-380, doi:10.5194/gmd-4-373-2011, 2011a.

Sander, S. P., Abbatt, J., Barker, J. R., Burkholder, J. B., Friedl, R. R., Golden, D. M., Huie, R. E., Kolb, C. E., Kurylo, M. J.,
Moortgat, G. K., Orkin, V. L., and Wine, P. H.: Chemical Kinetics and Photochemical Data for Use in Atmospheric Studies, Evaluation No. 17, JPL Publication 10-6, Jet Propulsion Laboratory, Pasadena, available at: http://jpldataeval.jpl.nasa.gov, 2011b.

Sander, R., Jöckel, P., Kirner, O., Kunert, A. T., Landgraf, J., and Pozzer, A.: The photolysis module JVAL-14, compatible with the MESSy standard, and the JVal PreProcessor (JVPP), Geosci. Model Dev., 7, 2653-2662, doi:10.5194/gmd-7-26532014, 2014.

Scaife, A. A., Butchart, N., Warner, C. D., and Swinbank, R.: Impact of a spectral gravity wave parametrization on the stratosphere in the Met Office Unified Model, J. Atmos. Sci., 59, 1473 1489, 2002.

Schraner, M., Rozanov, E., Schnadt Poberaj, C., Kenzelmann, P., Fischer, A. M., Zubov, V., Luo, B. P., Hoyle, C. R., Egorova, T., Fueglistaler, S., Brönnimann, S., Schmutz, W., and Peter, T.: Technical Note: Chemistry-climate model SOCOL: version 2.0 with improved transport and chemistry/microphysics schemes, Atmos. Chem. Phys., 8, 5957-5974, doi:10.5194/acp-8-59572008, 2008.

Schultz, M. G., Heil, A., Hoelzemann, J. J., Spessa, A., Thonicke, K., Goldammer, J. G., Held, A. C., Pereira, J. M. C., and van het Bolscher, M.: Global wildland fire emissions from 1960 to 2000, Glob. Biogeochem. Cy., 22, GB2002, doi:10.1029/2007GB003031, 2008.

Scinocca, J. F., McFarlane, N. A., Lazare, M., Li, J., and Plummer, D.: Technical Note: The CCCma third generation AGCM and its extension into the middle atmosphere, Atmos. Chem. Phys., 8, 7055-7074, doi:10.5194/acp-8-7055-2008, 2008.

Sekiya, T. and Sudo, K.: Role of meteorological variability in global tropospheric ozone during 1970-2008, J. Geophys. Res., 117, D18303, doi:10.1029/2012JD018054, 2012.

Sekiya, T. and Sudo, K.: Roles of transport and chemistry processes in global ozone change on interannual and multidecadal time scales, J. Geophys. Res., 119, 4903-4921, 2014.

Shibata, K., Deushi, M., Sekiyama, T. T., and Yoshimura, H.: Development of an MRI chemical transport model for the study of stratospheric Chemistry, Pap. Meteorol. Geophys., 55, 75-119, 2005.

Solanki, S. K. and Krivova, N. A.: Can solar variability explain global warming since 1970?, J. Geophys. Res., 108, 1200, doi:10.1029/2002JA009753, 2003.

Solomon, S., Kinnison, D. E., Bandoro, J., and Garcia, R.: Simulations of polar ozone depletion: an update, J. Geophys. Res., 120, 7958-7974, doi:doi:10.1002/2015JD023365, 2015.

Søvde, O. A., Matthes, S., Skowron, A., Iachetti, D., Lim, L., Hodnebrog, Ø., Di Genova, G., Pitari, G., Lee, D. S., Myhre, G., and Isaksen, I. S. A.: Aircraft emission mitigation by changing route altitude: A multi-model estimate of aircraft $\mathrm{NO}_{x}$ emission impact on $\mathrm{O}_{3}$ photochemistry, Atmos. Environ., 95, 468-479, doi:10.1016/j.atmosenv.2014.06.049, 2014.

SPARC: Assessment of stratospheric aerosol properties (ASAP), Technical report WCRP-124/WMO/TD-No. 1295/SPARC Report No. 4, SPARC, Toronto, Ontario, CA, 322 pp., 2006.

SPARC: SPARC CCMVal Report on the Evaluation of ChemistryClimate Models, edited by: Eyring, V., Shepherd, T. G., and Waugh, D. W., SPARC Report No. 5, WCRP-30/2010, WMO/TD - No. 40, available at: www.sparc-climate.org/ publications/sparc-reports/, 2010. 
SPARC: SPARC Report on the Lifetimes of Stratospheric OzoneDepleting Substances, Their Replacements, and Related Species, edited by: Ko, M., Newman, P., Reimann, S., and Strahan, S., SPARC Report No. 6, WCRP-15/2013, 2013.

Stenke, A., Schraner, M., Rozanov, E., Egorova, T., Luo, B., and Peter, T.: The SOCOL version 3.0 chemistry-climate model: description, evaluation, and implications from an advanced transport algorithm, Geosci. Model Dev., 6, 1407-1427, doi:10.5194/gmd-6-1407-2013, 2013.

Stieglitz, M., Ducharne, A., Koster, R. D., and Suarez, M. J.: The impact of detailed snow physics on the simulation of snowcover and subsurface thermodynamics at continental scales, J. Hydromet., 2, 228-242, 2001.

Stockwell, W. R., Kirchner, F., Kuhn, M., and Seefeld, S.: A new mechanism for regional atmospheric chemistry modeling, J. Geophys. Res., 102, 25847-25879, 1997.

Stockwell, D. Z. and Chipperfield, M. P.: A tropospheric chemical transport model: development and validation of the model transport schemes, Q. J. Roy. Meteor. Soc., 125, 1747-1783, doi:10.1002/qj.49712555714, 1999.

Stone, K. A., Morgenstern, O., Karoly, D. J., Klekociuk, A. R., French, W. J., Abraham, N. L., and Schofield, R.: Evaluation of the ACCESS - chemistry-climate model for the Southern Hemisphere, Atmos. Chem. Phys., 16, 2401-2415, doi:10.5194/acp16-2401-2016, 2016.

Strahan, S. E., Duncan, B. N., and Hoor, P.: Observationally derived transport diagnostics for the lowermost stratosphere and their application to the GMI chemistry and transport model, Atmos. Chem. Phys., 7, 2435-2445, doi:10.5194/acp-7-2435-2007, 2007

Sud, Y. C., Chao, W. C., and Walker, G. K.: Dependence of rainfall on vegetation: Theoretical consideration, simulation experiments, observations, and inferences from simulated atmospheric soundings, J. Arid. Environ., 25, 5-18, 1993.

Sudo, K. and Akimoto, H.: Global source attribution of tropospheric ozone: long-range transport from various source regions, J. Geophys. Res., 112, D12302, doi:10.1029/2006JD007992, 2007.

Sudo, K., Takahashi, M., Kurokawa, J., and Akimoto, H.: CHASER: A global chemical model of the troposphere 1. Model description, J. Geophys. Res., 107, 4339, doi:10.1029/2001JD001113, 2002.

Sukhodolov, T., Rozanov, E., Shapiro, A. I., Anet, J., Cagnazzo, C., Peter, T., and Schmutz, W.: Evaluation of the ECHAM family radiation codes performance in the representation of the solar signal, Geosci. Model Dev., 7, 2859-2866, doi:10.5194/gmd-72859-2014, 2014.

Sundqvist, H.: A parameterization scheme for non-convective condensation including prediction of cloud water content, Q. J. Roy. Meteor. Soc., 104, 677-690, 1978.

Szopa S., Balkanski, Y., Schulz, M., Bekki, S., Cugnet, D., FortemsCheiney, A., Turquety, S., Cozic, A., Déandreis, C., Hauglustaine, D., Idelkadi, A., Lathière, J., Lefèvre, F., Marchand, M., Vuolo, R., Yan, N., and Dufresne, J.-L.: Aerosol and ozone changes as forcing for climate evolution between 1850 and 2100, Clim. Dynam., 40, 2223-2250, 2013.

Takemura, T.: Distributions and climate effects of atmospheric aerosols from the preindustrial era to 2100 along Representative Concentration Pathways (RCPs) simulated using the global aerosol model SPRINTARS, Atmos. Chem. Phys., 12, 11555 11572, doi:10.5194/acp-12-11555-2012, 2012.

Takemura, T., Nozawa, T., Emori, S., Nakajima, T. Y., and Nakajima, T.: Simulation of climate response to aerosol direct and indirect effects with aerosol transport-radiation model, J. Geophys. Res., 110, D02202, doi:10.1029/2004JD005029, 2005.

Telford, P. J., Abraham, N. L., Archibald, A. T., Braesicke, P., Dalvi, M., Morgenstern, O., O'Connor, F. M., Richards, N. A. D., and Pyle, J. A.: Implementation of the Fast-JX Photolysis scheme (v6.4) into the UKCA component of the MetUM chemistry-climate model (v7.3), Geosci. Model Dev., 6, 161177, doi:10.5194/gmd-6-161-2013, 2013.

Tian, W. and Chipperfield, M. P.: A new coupled chemistry-climate model for the stratosphere: The importance of coupling for future $\mathrm{O}_{3}$ - climate predictions, Q. J. Roy. Meteor. Soc., 131, 281-303, 2005.

Tian, W., Chipperfield, M. P., Stevenson, D. S., Damoah, R., Dhomse, S., Dudhia, A., Pumphrey, H., and Bernath, P.: Effects of stratosphere-troposphere chemistry coupling on tropospheric ozone, J. Geophys. Res.-Atmos., 115, D00M04, doi:10.1029/2009JD013515, 2010.

Tie, X., Madronich, S., Walters, S., Edwards, D. P., Ginoux, P., Mahowald, N., Zhang, R., Lou, C., and Brasseur, G.: Assessment of the global impact of aerosols on tropospheric oxidants, J. Geophys. Res., 110, D03204, doi:10.1029/2004JD005359, 2005.

Tiedtke, M.: A comprehensive mass flux scheme for cumulus parameterization in large-scale models, Mon. Weather Rev., 117, 1179-1800, 1989.

Tilmes, S., Mills, M. J., Niemeier, U., Schmidt, H., Robock, A., Kravitz, B., Lamarque, J.-F., Pitari, G., and English, J. M.: A new Geoengineering Model Intercomparison Project (GeoMIP) experiment designed for climate and chemistry models, Geosci. Model Dev., 8, 43-49, doi:10.5194/gmd-8-43-2015, 2015.

Tilmes, S., Lamarque, J.-F., Emmons, L. K., Kinnison, D. E., Ma, P.-L., Liu, X., Ghan, S., Bardeen, C., Arnold, S., Deeter, M., Vitt, F., Ryerson, T., Elkins, J. W., Moore, F., Spackman, J. R., and Val Martin, M.: Description and evaluation of tropospheric chemistry and aerosols in the Community Earth System Model (CESM1.2), Geosci. Model Dev., 8, 1395-1426, doi:10.5194/gmd-8-13952015, 2015.

Tilmes, S., Lamarque, J.-F., Emmons, L. K., Kinnison, D. E., Marsh, D., Garcia, R. R., Smith, A. K., Neely, R. R., Conley, A., Vitt, F., Val Martin, M., Tanimoto, H., Simpson, I., Blake, D. R., and Blake, N.: Representation of the Community Earth System Model (CESM1) CAM4-chem within the ChemistryClimate Model Initiative (CCMI), Geosci. Model Dev., 9, 1853 1890, doi:10.5194/gmd-9-1853-2016, 2016.

Tompkins, A. M.: A prognostic parameterization for the subgridscale variability of water vapor and clouds in large- scale models and its use to diagnose cloud cover, J. Atmos. Sci., 59, 1917 1942, 2002

Tost, H., Jöckel, P., Kerkweg, A., Sander, R., and Lelieveld, J.: Technical note: A new comprehensive SCAVenging submodel for global atmospheric chemistry modelling, Atmos. Chem. Phys., 6, 565-574, doi:10.5194/acp-6-565-2006, 2006.

van der Werf, G. R., Randerson, J. T., Giglio, L., Collatz, G. J., Mu, M., Kasibhatla, P. S., Morton, D. C., DeFries, R. S., Jin, Y., and van Leeuwen, T. T.: Global fire emissions and the contribution of deforestation, savanna, forest, agricultural, and 
peat fires (1997-2009), Atmos. Chem. Phys., 10, 11707-11735, doi:10.5194/acp-10-11707-2010, 2010.

Vernier, J.-P., Thomason, L. W., Pommereau, J.-P., Bourassa, A., Pelon, J., Garnier, C., Hauchecorne, A., Blanot, L., Trepte, C., Degenstein, D., and Vargas, F.: Major influence of tropical volcanic eruptions on the stratospheric aerosol layer during the last decade, Geophys. Res. Lett., 38, L12807, doi:10.1029/2011GL047563, 2011.

Voldoire A., Sanchez-Gomez, E., Salas y Mélia, D., Decharme, B., Cassou, C., Sénési, S., Valcke, S., Beau, I., Alias, A., Chevallier, M., Déqué, M., Deshayes, J., Douville, H., Fernandez, E., Madec, G., Maisonnave, E., Moine, M.-P., Planton, S., SaintMartin, D., Szopa, S., Tytéca, S., Alkama, R., Bélamari, S., Braun, A., Coquart, L., and Chauvin, F.: The CNRM-CM5.1 global climate model: description and basic evaluation, Clim. Dynam., 40, 2091-2121, doi:10.1007/s00382-011-1259-y, 2012. von Salzen, K., Scinocca, J. F., McFarlane, N. A., Li, J., Cole, J. N. S., Plummer, D., Verseghy, D., Reader, M. C., Ma, X., Lazare, M., and Solheim, L.: The Canadian fourth generation atmospheric global climate model (CanAM4) - Part 1: Representation of physical processes, Atmos. Ocean, 51, 104-125, doi:10.1080/07055900.2012.755610, 2013.

Walters, D. N., Williams, K. D., Boutle, I. A., Bushell, A. C., Edwards, J. M., Field, P. R., Lock, A. P., Morcrette, C. J., Stratton, R. A., Wilkinson, J. M., Willett, M. R., Bellouin, N., BodasSalcedo, A., Brooks, M. E., Copsey, D., Earnshaw, P. D., Hardiman, S. C., Harris, C. M., Levine, R. C., MacLachlan, C., Manners, J. C., Martin, G. M., Milton, S. F., Palmer, M. D., Roberts, M. J., Rodríguez, J. M., Tennant, W. J., and Vidale, P. L.: The Met Office Unified Model Global Atmosphere 4.0 and JULES Global Land 4.0 configurations, Geosci. Model Dev., 7, 361-386, doi:10.5194/gmd-7-361-2014, 2014.

Wang, Y., Jacob, D., and Logan, J.: Global simulation of tropospheric $\mathrm{O}_{3}-\mathrm{NO}_{x}$-hydrocarbon chemistry 1 . Model formulation, J. Geophys. Res.-Atmos., 103, 10713-10725, doi:10.1029/98JD00158, 1998.

Wanninkhof, R. H.: Relationship between wind speed and gas exchange over the ocean, J. Geophys. Res., 97, 7373-7382, 1992.

Watanabe, M., Suzuki, T., Oishi, R., Komuro, Y., Watanabe, S., Emori, S., Takemura, T., Chikira, M., Ogura, T., Sekiguchi, M., Takata, K., Yamazaki, D., Yokohata, T., Nozawa, T., Hasumi, H., Tatebe, H., and Kimoto, M.: Improved climate simulation by MIROC5: Mean states, variability, and climate sensitivity, J. Climate, 23, 6312-6335, 2010.

Watanabe, S., Hajima, T., Sudo, K., Nagashima, T., Takemura, T., Okajima, H., Nozawa, T., Kawase, H., Abe, M., Yokohata, T., Ise, T., Sato, H., Kato, E., Takata, K., Emori, S., and Kawamiya, M.: MIROC-ESM 2010: model description and basic results of CMIP5-20c3m experiments, Geosci. Model Dev., 4, 845-872, doi:10.5194/gmd-4-845-2011, 2011.

Webster, S., Brown, A. R., Cameron, D. R., and Jones, C. P.: Improvements to the representation of orography in the Met Office Unified Model, Q. J. Roy. Meteor. Soc., 129, 1989-2010, 2003.

Wegner, T., Kinnison, D. E., Garcia, R. R., Madronich, S., and Solomon, S.: Polar stratospheric clouds in SD-WACCM4, J. Geophys. Res., 118, 1-12, doi:10.1002/jgrd.50415, 2013.
Wesely, M. L.: Parameterization of surface resistances to gaseous dry deposition in regional-scale numerical models, Atmos. Environ., 23, 1293-1304, doi:10.1016/0004-6981(89)90153-4, 1989.

Williamson, D. L. and Rasch, P. J.: Two-dimensional semiLagrangian transport with shape-preserving interpolation, Mon. Weather Rev., 117, 102-129, 1989.

Wilson, D. R., Bushell, A. C., Kerr-Munslow, A. M., Price, J. D., and Morcrette, C. J.: PC2: A prognostic cloud fraction and condensation scheme, I: Scheme description, Q. J. Roy. Meteor. Soc., 134, 2093-2107, 2008.

WMO: Scientific Assessment of Ozone Depletion: 2006, Global Ozone Research and Monitoring Project, Geneva, Switzerland, Report No. 50, 572 pp., 2007.

WMO:Scientific Assessment of Ozone Depletion: 2010, Global Ozone Research and Monitoring Project, Geneva, Switzerland, Report No. 52, 2011.

WMO: Scientific Assessment of Ozone Depletion: 2014, Global Ozone Research and Monitoring Project, Geneva, Switzerland, Report No. 55, 2015.

Yessad, K.: Horizontal diffusion computations in the cycle 24T1 of ARPEGE/IFS, ARPEGE Technical Documentation, 96 pp., 2001.

Yienger, J. J. and H. Levy: Empirical model of global soil-biogenic $\mathrm{NO}_{x}$ emissions, J. Geophys. Res.-Atmos., 100, 11447-11464, 10.1029/95jd00370, 1995.

Yoshimura, H. and Yukimoto, S.: Development of a Simple Coupler (Scup) for Earth System Modeling, Pap. Meteorol. Geophys., 59, 19-29, 2008.

Yukimoto, S., Yoshimura, H., Hosaka, M., Sakami, T., Tsujino, H., Hirabara, M., Tanaka, T. Y., Deushi, M., Obata, A., Nakano, H., Adachi, Y., Shindo, E., Yabu, S., Ose, T., and Kitoh, A.: Meteorological Research Institute Earth System Model Version 1 (MRIESM1) - Model Description, Tech. Rep. of MRI, 64, 83 pp. 2011.

Yukimoto, S., Adachi, Y., Hosaka, M., Sakami, T., Yoshimura, H., Hirabara, M., Tanaka, T. Y., Shindo, E., Tsujino, H., Deushi, M., Mizuta, R., Yabu, S., Obata, A., Nakano, H., Koshiro, T., Ose, T., and Kitoh, A.: A new global climate model of the Meteorological Research Institute: MRI-CGCM3 - Model description and basic performance, J. Meteorol. Soc. Jpn., 90, 23-64, 2012.

Zdunkowski, W. G., Welch, R. M., and Korb, G.: An investigation of the structure of typical two-stream-methods for the calculation of solar fluxes and heating rates in clouds, Contr. Phys. Atmos. 53, 147-166, 1980.

Zeng, G. and Pyle, J. A.: Changes in tropospheric ozone between 2000 and 2100 modeled in a chemistry-climate model, Geophys. Res. Lett., 30, 1392, doi:10.1029/2002GL016708, 2003.

Zhang, L., Moran, M., Makar, P., Brook, J., and Gong, S.: Modelling gaseous dry deposition in AURAMS - a united regional air quality modelling system, Atmos. Environ., 36, 537-560, 2002.

Zhang, L., Brook, J. R., and Vet, R.: A revised parameterization for gaseous dry deposition in air-quality models, Atmos. Chem. Phys., 3, 2067-2082, doi:10.5194/acp-3-2067-2003, 2003. 